



\section{Välfärdspolitiska förhållanden i Västnorden}

Färöarna, Grönland och Island

Eva Sundström

TemaNord 2006:520 
Välfärdspolitiska förhållanden i Västnorden

Färöarna, Grönland och Island

TemaNord 2006:520

(c) Nordiska ministerrådet, Köpenhamn 2006

ISBN 92-893-1291-2

Tryck: Elanders Gotab AB

Omslag: Kjell Olsson, NMR/PUB

Layout: NMR/PUB

Omslagsfoto: Stefan Fallgren/Bildhuset

Upplaga: 300

Tryckt på miljövänligt papper som uppfyller kraven i den nordiska miljösvanemärkningen.

Publikationen kan beställas på www.norden.org/order. Fler publikationer på

www.norden.org/publikationer

Printed in Sweden

Nordiska ministerrådet

Store Strandstræde 18

DK-1255 Köpenhamn K

Telefon (+45) 33960200

Fax (+45) 33960202

\section{Nordiska rådet}

Store Strandstræde 18

DK-1255 Köpenhamn K

Telefon (+45) 33960400

Fax (+45) 33111870

www.norden.org

\section{Det nordiska samarbetet}

Det nordiska samarbetet hör till de äldsta och mest omfattande regionala samarbetsformerna i världen. Samarbetet omfattar Danmark, Finland, Island, Norge och Sverige samt Färöarna, Grönland och Åland. Det stärker samhörigheten mellan de nordiska länderna med respekt för nationella skillnader och likheter. Samarbetet ger bättre möjligheter att hävda nordiska intressen i omvärlden och främja goda grannförhållanden.

Samarbetet formaliserades år 1952 då Nordiska rådet grundades som ett forum för parlamentarikerna och regeringarna i de nordiska länderna. År 1962 ingick de nordiska länderna Helsingforsavtalet, som sedan dess har utgjort den grundläggande ramen för det nordiska samarbetet. År 1971 bildades Nordiska ministerrådet som ett formellt forum för samarbete mellan de nordiska regeringarna och den politiska ledningen i de självstyrande områdena Färöarna, Grönland och Åland. 


\section{Förord}

Den primära avsikten med föreliggande rapport är att skapa en övergripande bild av dagsläget när det gäller välfärd och välfärdsforskning i västnorden samt att presentera den empiri och forskning som välfärdspolitiska frågor för närvarande kringgärdas av. Ytterligare ett syfte har varit att ge förslag till forskningsområden för fortsatta västnordiska studier. Arbetet har därmed i första hand motiverats av en strävan att åstadkomma ett övergripande kunskapsmässigt underlag. De konklusioner som presenteras är ämnade att stimulera till nya problemformuleringar och fortsatta länderspecifika och jämförande studier. Endast engelskspråkiga texter och texter tillgängliga på skandinaviska språk har använts. Arbetet har finansierats med medel från Nordiska Ministerrådets Välfärdsforskningsprogram via Norges Forskningsråd. Jag vill rikta ett stort tack till Petra Jonsdóttir Joensen, Beinta í Jákupsstovu och Gestur Hovgaard i Färöarna, Tom Greiffenberg, Birger Poppel, Kirsten Olesen och Wolfgang Kahlig i Grönland samt till Gudny Eydal, Stefán Ólafsson, Guðdbjörg Linda Rafnsdóttir och Ingibjörg Broddadóttir i Island som bistått mig i arbetet genom att tillhandahålla källmaterial och empiriska underlag och som också under arbetets gång har givit mig mycket konstruktiv kritik till texten. 



\section{Innehållsförteckning}

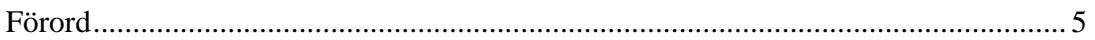

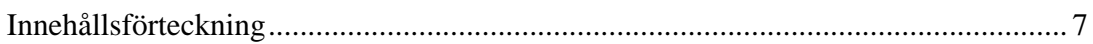

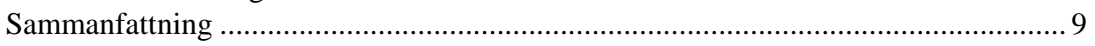

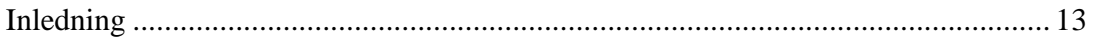

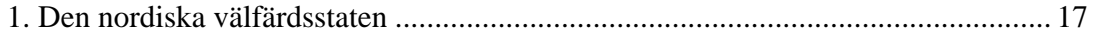

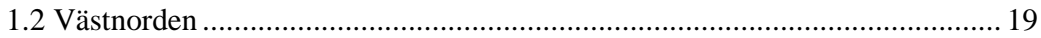

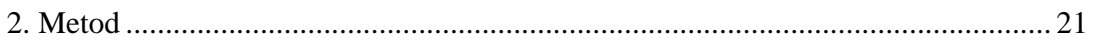

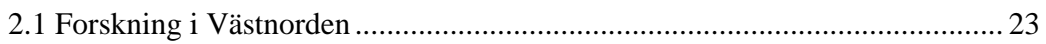

Etiska spörsmål ................................................................................ 25

3. Allmänt om Färöarna, Grönland och Island ........................................................ 29

3.1 Självständighet och hemstyre ..................................................................... 30

3.2 Basnäringar, nya näringsgrenar, arbete och migration ................................. 32

3.3 Västnordisk arbetsmarknad och arbetsmarknadspolitik ................................. 38

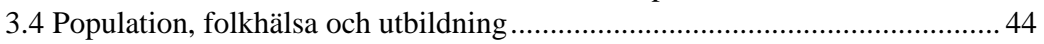

Folkhälsa........................................................................................ 44

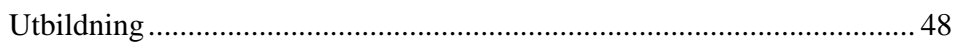

4. De västnordiska socialförsäkringssystemen ................................................... 51

Marginaliseringstendenser i Västnorden ............................................. 58

5. Den västnordiska välfärdsstatens politiska och ekonomiska inriktning.....................63

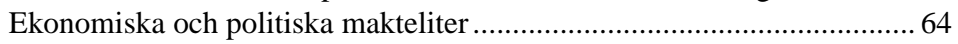

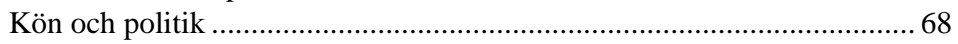

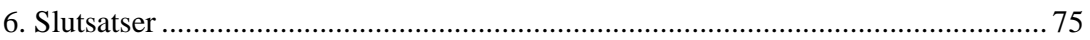

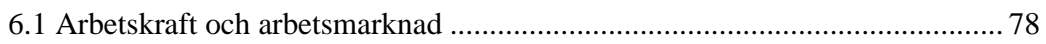

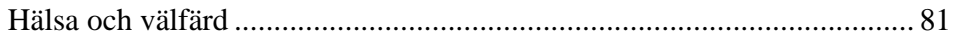

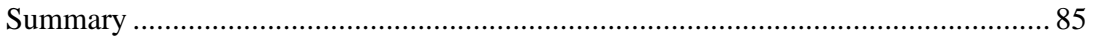

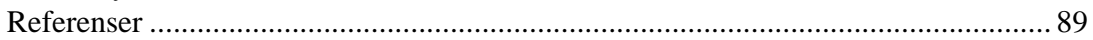





\section{Sammanfattning}

Den nordiska välfärdsstatsmodellen kännetecknas av högt arbetsmarknadsdeltagande bland kvinnor och män, universalistiska principer för fördelning av sociala rättigheter, relativt generösa ersättningsnivåer, omfattande offentlig servicesektor och ett begränsat individuellt beroende av ekonomiskt stöd från familjen. Trots att Färöarna, Grönland och Island geopolitisk tillhör Norden inkluderas de sällan i internationellt jämförande välfärdsstatsstudier. Vissa analyser tyder dock på att den välfärdspolitik som bedrivits i dessa områden delvis skiljer sig från övriga Norden. Syftet med rapporten är dels att utgöra en kunskapsöversikt över befintlig samhällsvetenskaplig och välfärdsrelaterad forskning kring Västnorden och dels att jämföra välfärdspolitiska indikatorer i vid bemärkelse från Färöarna, Grönland och Island för att identifiera såväl länderspecifika som gemensamma drag i utformningen av de västnordiska områdenas välfärdspolitiska system. Slutsatser från tidigare och pågående välfärdsrelaterad forskning från de tre områdena presenteras och vad som framstår som mer generella, alternativt mer specifika drag i de olika västnordiska samhällena lyfts fram. Utformningen av de västnordiska välfärdspolitiska programmen, framförallt de som rör olika typer av socialförsäkringar, beskrivs översiktligt och jämförs med varandra och med östra Norden. De slutsatser som presenteras är främst ämnade att stimulera till nya problemformuleringar och fortsatta länderspecifika och jämförande studier. Endast engelskspråkiga texter och texter tillgängliga på skandinaviska språk har använts. Det material som använts består av rapporter, forskningsresultat och analyser samt tillgängligt offentligt statistiskt material. Därtill har material som publicerats på Internet utnyttjats. Delar av informationen bygger på egna beräkningar och omräkningar och bör därför betraktas som indikativa. 
De välfärdspolitiska förhållandena i Västnorden både liknar och skiljer sig från övriga Norden. Socialförsäkringssystemen är i huvudsak skattefinansierade och universella på ett liknande sätt som i övriga Norden. I jämförelse med östra Norden är ersättningsnivåerna överlag låga. Som en möjlig förklaring till låga ersättningsnivåer och till den hushållsbaserade beräkningen för vissa bidrag och pensioner föreslås betydelsen av fiskerinäringens förutsättningar och de regelsystem som kringgärdar arbetskraften, samt offentliga förväntningar på att naturahushållning och biinkomster från jakt och fiske utgör väsentliga alternativa försörjningsmöjligheter för individer. Den ekonomiska fattigdomen kan därför vara betydande även om människor har andra försörjningsmöjligheter. I det grönländska fallet är den ekonomiska fattigdomen starkt relaterad till olika folkhälsoaspekter. Idag är den färöiska och isländska förvärvsfrekvensen högre bland både män och kvinnor än i de östnordiska länderna. Inkomstskillnaderna mellan män och kvinnor är betydande och relaterade till köns- och lönesegregerade arbetsmarknader och till kvinnors större andel bland deltidsanställda. Jämfört med de traditionella socialförsäkringssystemen är också de mer nytillkomna, så som den färöiska och isländska föräldraförsäkringen, uppbyggda kring ersättningsnivåer i paritet med det tillfälliga bortfallet av individuell arbetsinkomst. Kvinnors lägre inkomster återspeglas i att andelen ensamförsörjande kvinnor med barn är betydande bland socialbidragstagare. Social service, särskilt barnomsorg, har under 1990-talet varit under kraftig uppbyggnad och tillgänglig på villkor liknande de i övriga Norden. Såväl Färöarna som Grönland och Island har unga befolkningar. En större andel äldre än vad som är fallet i de östnordiska länderna är förvärvsarbetande även efter den formella pensionsåldern. Frågan reses om och på vilket sätt orsakerna till detta hänger samman med livsstil/kulturella alternativt ideologiska aspekter och/eller med ekonomiska förhållanden. Ytterligare en aspekt som aktualiseras inom ramen för projektet är betydelsen av sambeskattning för kvinnors och mäns arbetsmarkandsdeltagande. I vilken mån begränsar, alternativt stimulerar, sambeskattning individers i olika inkomstgrupper förvärvsarbete?

Inga större nationella eller jämförande västnordiska välfärds- eller socialpolitiska utvärderande forskningsresultat föreligger, men offentlig statistik indikerar att hälso- och inkomstskillnader mellan låg- och högutbildade, yngre - äldre, bosatta i stad eller landsbygd eller inrikes - utrikes 
födda är markanta och möjligen delvis följer ett annorlunda mönster än i övriga Norden. Att vara invandrare eller ha östnordisk utbildning har fram till nu, framförallt i Grönland, inneburit tillträde till bättre betalda arbeten. Länderna befinner sig i en brytpunkt där allt fler yngre söker sig till regelrätta anställningar med fasta inkomster medan ett minskande antal personer har sin utkomst i självhushåll kombinerat med periodvisa anställningar inom framförallt fiskeindustrierna. Detta ställer nya krav på de västnordiska välfärdssystemen. När det gäller beskattnings- och socialförsäkringspolitik bör nationella och jämförande studier genomföras för att identifiera inbyggda segregerings- och fattigdomsfällor i marginalskatteeffekter och i bidragssystemens utformning. Välfärds- och arbetsmarknadspolitikens utformning bör analyseras närmare för att identifiera inlåsningseffekter samt relationen mellan ekonomisk konjunktur, migrationsmönster, utbildnings- eller omskolningsmöjligheter och arbetstillfällen.

Tidigare västnordisk forskning pekar på att kraftiga ekonomiska och politiska investeringar i fiskerinäringen i kombination med underinvesteringar i forskning och utveckling, i syfte att utveckla förutsättningar och möjligheter inom nya sektorer, har lett till en ekonomisk och välfärdspolitisk glapp eller mismatch. Delvis mot bakgrund av de små befolkningarna och fiskenäringens dominans som inkomstkälla och exportvara, och av framförallt Färöarnas och Grönlands relationer till Danmark, understryks i ett flertal rapporter betydelsen av ekonomiska makteliter och politiska styrkepositioner som i sina strukturer och målsättningar verkar skilja sig från den välfärdspolitik som bedrivits i östra Norden. Ytterligare ett studieområde av vikt är därför relationen mellan ekonomiska egenintressen, vidare intressegrupper och statens roll i nationella ekonomiska och socialpolitiska prioriteringar. I vilken grad har statliga initiativ inslag av särintressen och hur ser möjligheterna ut för de västnordiska länderna att planera och agera långsiktigt, givet de geografiska, demografiska och ekonomiska förutsättningarna och de existerande konstellationerna av ekonomiska och politiska maktrelationer? Det föreligger även behov av att studera och diskutera de sätt på vilka hemstyren och Danmark utövar politisk och ekonomisk makt och hur de politiska systemens legitimitet kan stärkas, bland annat i relation till gruppers sociala och ekonomiska kapital och möjliga samhällskonflikter med socioekonomiska och strukturella förtecken 
12 Välfärdspolitiska förhållanden i Västnorden - Färöarna Grönland och Island 


\section{Inledning}

Projektets syfte är att utgöra en kunskapsöversikt över befintlig skandinavisk- och engelskspråkig samhällsvetenskaplig och välfärdsrelaterad forskning kring Västnorden samt att jämföra välfärdspolitiska indikatorer i vid bemärkelse från Färöarna, Grönland och Island för att identifiera såväl länderspecifika som gemensamma drag i utformningen av de västnordiska områdenas välfärdspolitiska system.

De nordiska länderna brukar allmänt framhållas som relativt generösa välfärdsstater med universella socialförsäkrings- och bidragssystem. I de olika studier som genomförts förekommer dock sällan eller aldrig de västnordiska områdena som geopolitiskt tillhör Norden, nämligen Färöarna, Grönland och Island. Av dessa är endast Island en självständig nation. De övriga två har under 1900-talet och välfärdsstatens framväxt varit danska kolonier och ingår numera i den danska riksgemenskapen med gemensam grundlag. De styrs dock politiskt idag i huvudsak av färöiskt respektive grönländskt hemstyre. Delvis med undantag för Island behandlar tidigare forskning kring Västnorden framförallt tillgång till och strategier för utnyttjande av naturresurser, effekter av miljöförstörning på delar av naturresurser och befolkningar samt förutsättningar för nuvarande och framtida näringsgrenar. Det finns förvisso ett antal studier som på olika sätt berör styrelseskick, politiska grupperingar och strategier samt hälsa men analyser av sociala förhållanden och ländernas respektive välfärdspolitiska strukturer och målsättningar är mer sällsynta. Därmed saknas också till del studier av förekomsten och utformningen av de västnordiska välfärdspolitiska systemen samt undersökningar av de socioekonomiska effekter de på olika sätt både medverkar till att producera och till att upprätthålla och som dess invånare och välfärdspolitiska institutioner i sina dagliga verksamheter har att förhålla sig till. 
Mot bakgrund av förbindelsen med Danmark och med Norden som en närliggande kulturell och välfärdspolitisk influens ligger det nära till hands att anta att de färöiska, grönländska och isländska välfärdssystemen till sin utformning påminner om dem som återfinns i de övriga nordiska länderna och som brukar betecknas som den nordiska modellen. Färöarna och Grönland lyder fortfarande till viss del lyder under dansk överhöghet. Under senare år har man dock, via färöiskt och grönländskt hemstyre, ökat sin politiska och ekonomiska autonomi samt övertagit stora delar av den administration som tidigare ombesörjdes av Danmark. Det är därför rimligt att anta att dessa områden liknar Danmark och övriga Norden i sin välfärdspolitiska uppbyggnad. Island är sedan 1944 en självständig nation. Landet har också under lång tid upprätthållit ett nära ekonomiskt och politiskt samarbete med de övriga nordiska länderna. Mot bakgrund av detta och att islänningar uppvisar attityder till jämlikhet som i många avseenden överensstämmer med dem som finns representerade i de östnordiska länderna kan isländsk välfärdspolitik och välfärdspolitiska lösningar förmodas att i betydande avseenden vara närbesläktade med dem i övriga Norden. Det som ändå i viss mån talar emot större likheter är att de västnordiska områdena ofta beskrivs som primärnäringssamfund, präglade av mycket specifika politiska, ekonomiska, geografiska och demografiska förutsättningar och livsvillkor. De västnordiska områdenas befolkningar är också mycket små. Möjligen har dessa förutsättningar i sin tur samverkat till att frammana något annorlunda välfärdspolitiska överväganden och handlingsstrategier, vilka på olika sätt avviker från dem som finns representerade inom de övriga nordiska länderna. Det huvudsakliga syftet med följande rapport är att presentera slutsatser från tidigare och pågående forskning från de tre områdena samt att, på en mycket övergripande nivå, lyfta fram vad som framstår som mer generella, alternativt mer specifika drag i de olika västnordiska samhällena. Utformningen av de västnordiska välfärdspolitiska programmen, framförallt de som rör olika typer av socialförsäkringar, beskrivs översiktligt och jämförs mycket preliminärt med varandra och med östra Norden. I den mån materialet tillåter presenteras också några tänkbara indikationer på effekter av västnordisk välfärdspolitik på dess befolkning. Den primära avsikten med rapporten är således att skapa en övergripande bild av dagsläget när det gäller välfärd och välfärdsforskning i västnorden samt att presentera den empiri och forskning som välfärdspolitiska frågor för 
närvarande kringgärdas av. Ytterligare ett syfte har varit att identifiera eventuella brister som förhindrar jämförande analyser samt att formulera områden för fortsatta studier. Arbetet har därmed i första hand motiverats av en strävan att åstadkomma ett övergripande kunskapsmässigt underlag. De konklusioner som presenteras är därför främst ämnade att stimulera till nya problemformuleringar och fortsatta länderspecifika och jämförande studier. Endast engelskspråkiga texter och texter tillgängliga på skandinaviska språk har använts.

Rapporten är upplagd enligt teman snarare än efter de länder som ingår. Detta är ett val som motiverats av den tidsbegränsade ramen för föreliggande arbete, svårigheter att finna jämförbara empiriska material samt med att det övergripande syftet med arbetet varit att göra en sammanställning baserad på de infallsvinklar på välfärd som studerats i Västnorden som region snarare än i respektive land. I texten tas ett större antal välfärdspolitiskt relevanta områden upp men inga mer djupgående analyser av specifika fält har gjorts. Bristande möjligheter att genomföra mer djupgående och systematiska analyser där olika samband mellan orsaker och effekter studeras är också något som i olika sammanhang tagits upp som ett forskningsmässigt problem i delar av Västnorden. Rapporten inleds med en kortfattad referens till östnordisk forskning och följs därefter av en sammanfattning av vad som i tidigare forskningsrapporter identifierats som utmärkande för den nordiska välfärdsstatsmodellen. I metodavsnittet beskrivs tillvägagångssätt för föreliggande arbete och några av de metodologiska problem som framkommit i arbetet med rapporten. Därefter följer en redogörelse av de västnordiska områdena och av den välfärdspolitiska forskning och närliggande forskningsområden som pågått och pågår i Västnorden under 1990-talet och framåt. En sammanfattning av de socialförsäkringssystem som förekommer i Färöarna, Grönland och Island är inkluderad. Studier av de västnordiska välfärdsstaternas politiska och ekonomiska inriktning presenteras och relateras till dess sociala, ekonomiska och politiska förutsättningar. Arbetet avslutas med en sammanfattande diskussion samt med förslag till forskningsområden att initiera, vidareutveckla eller fördjupa. 


\section{Den nordiska välfärdsstaten}

Den nordiska välfärdsmodellen har karaktäriserats som uppbyggd kring en jämförelsevis stark stat med ett omfattande ansvar för och finansiering av socialförsäkringssystem och offentlig sektor, en aktiv arbetsmarknadspolitik och ett högt arbetsmarkandsdeltagande bland både män och kvinnor samt av ett begränsat individuellt beroende av ekonomiskt stöd från familjen. Ekonomisk omfördelning via skattefinansierade bidrag och ett stort utbud av subventionerad offentlig samhällsservice medverkar till utjämningseffekter i inkomstskillnader mellan olika sociala grupper och till att andelen fattiga är bland de lägsta i världen. Tillträdesregler till socialförsäkringssystemen och service baseras på universalism som i huvudsak utgår från individers uppehållstillstånd/bostadsort snarare än medborgarskap och kombineras med inkomstrelaterade socialförsäkringsprogram där både privatanställda och offentliganställda ingår i samma försäkringssystem. Även om ersättningsnivåerna, betalningssystemen, tillträdesregler och varaktigheten i utbetalningsperioder skiljer sig åt mellan länderna är ersättningsnivåerna, ur ett europeiskt perspektiv, ganska generösa (Vogel 1997, Vogel et al 2004). Detta förhållande brukar ges legitimitetsgrundande förklaringar genom att de motsvarar och representerar nordiska värderingar kring jämlikhet och solidaritet, vilka bärs upp och motiveras via socialförsäkringssystem med en bred inkludering av olika socioekonomiska grupper, samt antaganden om minskade stigmatiseringseffekter.

Framförallt har länken mellan förvärvsarbete och arbetsmarknadspolitik understrukits som en grundläggande förutsättning för en nordisk välfärdspolitik. Aktiv och till viss del samordnad utbildnings- och arbetsmarknadspolitik, hög förvärvsfrekvens, resursomfördelning med universalism som politiskt verktyg i fördelning av sociala rättigheter och välfärdstjänster har medfört att selektiva åtgärder och fördelningsprinci- 
per grundade på moraliska, familjerelaterade eller ekonomiska argument för behovsprövning har getts förhållandevis litet utrymme. Den nordiska välfärdsstaten har framhållits som en modell som ger bättre förutsättningar för ekonomisk, social och politisk jämställdhet än vad som är fallet i flertalet västliga demokratier. Här framhålls inte enbart den betydande ekonomiska omfördelningen relaterad till arbetsmarknadsdeltagande utan också att man inom den nordiska modellen, och kanske i högre grad än i andra delar av Europa, har lagt sig vinn om att minska materiella och klassrelaterade skillnader även inom kulturella områden i en vidare bemärkelse så som idrotts- och föreningsliv.

Även om det finns tydliga indikationer på att skilda välfärdspolitiska lösningar har sina rötter i olika politiska och socioekonomiska konstellationer i enskilda länder så påverkas dess utformning och framväxt också av andra strukturella och historiska faktorer som industrialiseringsperiod, storleken på den inhemska ekonomin, grad av exportberoende och specialisering av exportvaror, koncentration av ekonomiska centra, historiska arv när det gäller arbetsgivarorganisationer och andra världskrigets effekter på respektive land (Huber och Stephens 2001). Till detta skulle kunna tilläggas omfattningen av lönearbete i förhållande till personer som har sin främsta utkomst, det vill säga är förhållandevis självförsörjande, genom naturahushållning. Enligt Christiansen och Petersen (2001) finns ingen egentlig förklaring till likheterna mellan de nordiska länderna men ett tydligt inspirationsutbyte och samarbete länderna emellan har förekommit och likartade planer och program har genomförts ungefär samtidigt. Dock har 1990-talets nordiska välfärdsstatsforskning påvisat en del betydelsefulla inomnordiska nationella skillnader i politisk orientering och i välfärdsprogram av vikt för individers förutsättningar att skapa sig ett individuellt ekonomiskt oberoende och tillträde till sociala rättigheter. Variationerna gäller framförallt synen på förhållandet mellan välfärdsstaten, individen och familjens omsorgsansvar. Det innebär i praktiken att ersättningsnivåer och tidsramar för olika försäkringar varierar och att det inom de olika länderna finns olika synsätt representerade på omfattningen av icke-statliga organisationers roll i utformning och utbudet av social service. Ytterligare skillnader återspeglas i de roller kvinnor och män formellt och informellt åläggs i relation till försörjningsansvar, föräldraskap och till vård av äldre anhöriga. Gällande regelverk och förväntningar i respektive land påverkar avsevärt både kvinnors förutsätt- 
ningar på arbetsmarknaden och mäns möjligheter att ta omsorgsansvar (Leira 1992, Anttonen och Sipilä 1996, Bergqvist et al 1999, Ferrarini 2003, Kautto et al 2001). Med motiveringen att stärka och stödja medborgares möjligheter att själva styra sina liv och aktivt delta i det sociala, politiska och ekonomiska livet har diskussionerna kring ekonomisk, politisk och social jämställdhet mellan könen alltmer kommit att framhållas som ytterligare viktiga målsättningar för välfärdspolitiska diskussioner och handlingslinjer.

\subsection{Västnorden}

Färöarna, Grönland och, med få undantag, även Island är sällan eller aldrig inkluderade i studier av nordiska välfärdsmodeller och det finns endast ett fåtal redogörelser av dess historiska välfärdspolitiska framväxt, dåtida och nuvarande strukturer och socialpolitiska program. Likaså är studier av den västnordiska välfärdsstatens eventuella sociala och ekonomiska konsekvenser för samhällena i stort sällsynta. Studier av hur skilda välfärdspolitiska program kommer olika befolkningsgrupper inom länderna till del saknas också nästan helt. ${ }^{1}$ En förklaring till bristerna är att samhällena, och då särskilt Färöarna och Grönland, är små och har knappa egna utrednings- och forskningsresurser, i synnerhet för mer samhällsvetenskapligt inriktade studier. Ytterligare ett skäl är kanske att Färöarna och Grönland inte är självständiga stater och därmed verkar "glömmas bort" eller hamna i skuggan av den danska staten. De statistiska underlagen, framförallt från Färöarna, är bristfälliga, något som i sin tur försvårar genomförandet av mer kvantitativa jämförande analyser. För Grönlands del har levnadsvillkorsundersökningar genomförts 1973 och 1994 och data som möjliggör tidsmässiga och internationella jämförelser bör därför finnas. Island är dock det land som på senare tid allt oftare kommit att ingå i jämförande välfärdsundersökningar.

I ett flertal artiklar har Stefán Ólafsson argumenterat för att Island bara delvis kan sägas ingå i en nordisk välfärdsstatsmodell (1999, 2003a, 2003b). Eftersom Färöarna och Grönland fortfarande befinner sig under dansk överhöghet har antagandet om att dessa områden i hög grad liknar

\footnotetext{
${ }^{1}$ Möjligen finns studier på respektive nationella språk. Som inledningsvis påpekats avses i föreliggande text enbart studier presenterade på skandinaviska eller engelska.
} 
Danmark i sin välfärdspolitiska utformning varit en utgångspunkt i föreliggande arbete. I den mån något av länderna avviker, bör det vara Färöarna eftersom landet har haft hemstyre under en längre tid än Grönland och därmed har hunnit fjärma sig från det danska politiska arvet och från expert- och arbetskraftsberoendet. Den motsatshypotes som också ställdes upp i inledningsskedet grundade sig på att de specifika förhållanden som präglar Västnorden. De har alla, en längre bit in på 1900-talet än länderna i östra Norden, fungerat som primärnäringssamfund och danska kolonier som utvecklats i olika takt under efterkrigstiden. Länderna har små och unga befolkningar som delvis är geografiskt spridda över till del fortfarande svårtillgängliga områden. Likaså är länderna i sig själva geografiskt tämligen isolerade och nationalekonomiskt och arbetsmarknadsmässigt opererar de med fiskeindustrin som dominerande exportnäring. Detta sammantaget bäddar för andra ekonomiska och välfärdspolitiska förutsättningar, prioriteringar och lösningar än länderna i östra Norden. Det borde också bygga på och strukturera en något annorlunda relation mellan individ, arbete och välfärdsstat än vad som varit fallet i övriga Norden. 


\section{Metod}

Det material som använts består av tillgängliga rapporter, forskningsresultat och analyser samt befintligt offentligt statistiskt material så som nationella årsböcker och liknande publikationer. Därtill har material som publicerats på Internet utnyttjats. Det rör sig framförallt om konferenspapers, delrapporter från forskningsprojekt, publicerade politiska uttalanden och andra offentliga politiska dokument, statistiska bulletiner och rapporter samt tidnings- och tidsskriftsartiklar. Det innebär att delar av informationen är preliminär och tentativ men återspeglar förhoppningsvis ändå ganska bra faktiska förhållanden och vilka frågor som betraktas som relevanta och viktiga i de västnordiska områdena. På grund av bristande språkkunskaper har jag enbart utnyttjat texter och annat material som kommuniceras på skandinaviska eller engelska och inte tagit del av texter publicerade på färöiska, grönländska eller isländska. Jag har valt att väva in tillgängliga forskningsresultat, analyser, statistisk information och övrigt material löpande i texten. Delar av informationen bygger på egna beräkningar och omräkningar och bör därför betraktas som preliminära och indikativa.

Grönland och Färöarna och ofta även Island har fram till nyligen helt eller delvis saknats i de gemensamma nordiska statistiska databaserna NOSOSCO (Social Protection in the Nordic Countries) och NOMESCO (Health Statistics in the Nordic Countries). För år 2004 finns de representerade inom vissa områden. De offentliga statistiska underlagen rörande välfärdspolitiska indikatorer från Västnorden är ojämn. De största svagheterna finns i det färöiska statistiska materialet, till exempel finns ingen egentlig information om färöiska arbetskraftstal och arbetslöshet utan enbart uppskattningar gjorda på basis av ekonomiska uppgifter från arbetsgivare, arbetslöshetskassor och socialkontor. Därtill erbjuder Färöarnas offentliga statistik enbart uppgifter om totala summor utbetalda 
för löner inom olika yrkesområden eller olika sociala förmåner medan upplysningar om antal personer som erhållit bidrag eller ersättning från socialförsäkringssystemen, årsinkomster för olika yrkesgrupper eller andra typer av grupperingar helt eller delvis saknas. Sannolikt finns dock mycket information och beräkningar inom olika förvaltningar även om den ännu inte är samlad eller sammanställd på ett mer koncentrerat och systematiskt sätt. En mer omfattande databas är under uppbyggnad via Färöarnas statistiska institut Hagstova Føroya. Grönland är, i förhållande till sin befolkningsstorlek, väldokumenterat när det gäller både statistisk information och vetenskapliga texter, dock finns tecken som tyder på att mätningarna har en "eurocentrisk" tyngdpunkt. Till exempel är förhållandet mellan individers förvärvsarbete och alternativa utkomstmöjligheter lite oklar. Därmed framträder relationer som den mellan arbete, inkomst, levnadsnivå och hälsa inte riktigt efter samma mönster som i östra Norden. I Grönland pågår inom ramen för ett flertal mer omfattande forskningsprojekt idag ett arbete med att förbättra det statistiska underlaget för välfärdsindikatorer inom ramen för studier av hälsa, arbetsmarknadsförhållanden och levnadsnivå och att relatera valen av indikatorer till grönländska och arktiska förhållanden. Islands statistiska institut är det som kommit längst i arbetet med att utveckla mer komplexa databaser över olika välfärdsrelaterade komponenter.

Det finns endast få västnordiska studier kring social stratifiering och det går därför bara sällan att se i vilken utsträckning olika typer av ersättningsnivåer eller förekomster av sociala, ekonomiska eller medicinska problem samvarierar med till exempel ålder, utbildningsnivå, inkomst, arbetslöshet, kön, bostadsort och liknande. Bland de arbeten jag funnit är de mest omfattande publicerade kring isländska förhållanden och bland dessa utgör de flesta studier kring ojämlikheter grundade i könsrelaterade strukturer (se t ex Einarsdóttir et al 2002, Eydal et al 2003a, 2003b, 2003c). Även ett antal grönländska studier har genomförts, de mest detaljerade av Grönlands statistik (se till exempel den grönländska statistiska enhetens årsbok Greenland 2001-2002. Statistical Yearbook och annat material som publicerats av Statistics Greenland). Dessa understryker framförallt olikheterna mellan befolkningar i tätbebyggda områden jämfört med personer bosatta i glest bebyggda områden. Det finns också ett antal studier presenterade inom medicinsk forskning och folkhälsoforskning men med hänvisning till omfattningen på detta arbete ingår de bara 
marginellt i föreliggande studie. Som framgår längre fram i texten framläggs antaganden om vissa samband mellan medicinska och socioekonomiska förhållanden i olika nationella och jämförande forskningsrapporter. En del texter är mer preliminära eller tentativa i sina ansatser och består av empiriska studier kopplade till geografiskt eller på annat sätt begränsade områden (se t ex, Kahlig 1999, 2002, Nilsson 2001, Gaini 2003, Rygaard 2003, Thorsteinsson 2004). Det betyder inte att de därmed är att betrakta som oviktiga eller oanvändbara utan snarare att det inte går att bilda sig någon egentlig uppfattning om omfattningen av vissa lokalt studerade problem eller fenomen och därmed inte i vilken utsträckning de är specifika för vissa grupper, områden eller tidpunkter eller om resultaten är generaliserbara på en nationell nivå. De utmärkande politiska, ekonomiska och geografiska förhållandena som råder i Västnorden innebär också att det i vissa fall krävs tillgång till lokalkunskaper och informationskällor för att studera eventuella samband mellan olika faktorer.

\subsection{Forskning i Västnorden}

De nationella och internationella samhällsvetenskapligt inriktade forskningsprogrammen i Grönland är ett gemensamt dansk-grönländskt ansvarsområde och forskning finansieras av och bedrivs i båda länderna. Prioritering av grönländsk samhällsvetenskaplig forskning görs av hemstyret och med olika danska institutioner så som det danska Statens Institut for Folkesundhet (se också Greenland 2001-2002 Statistical Yearbook, 2002, kap 16). De grönländska forskningspolitiska målen formuleras av det grönländska hemstyret och ett antal forskningsinstitutioner har upprättats under de senaste 25 åren. Samhällsvetenskaplig forskning genomförs i huvudsak av Grönlands universitet i samarbete med Grönlands Statistik och med olika departement inom hemstyret. En undersökning av levnadsförhållanden har initierats av Grönlands Statistik. Projektet upptogs år 2000 som ett Sustainable Development Working Project under Artiska Rådet. Det pågår under förkortningen SLiCA och är knutet till studier om arktiska ursprungsbefolkningar och bärkraftig utveckling. Projektet är till sitt innehåll kopplat till det grönländska hemstyrets forskningsstrategi som utarbetats för perioderna 1998-2000 och 2003-2007. Huvuddelen av den forskning som pågår i Grönland finansieras med 
danska medel och genomförs av dansk vetenskaplig och teknisk personal (Greenland 2001-2002 Statistical Yearbook, 2002, 188). Kahlig (2003) diskuterar kvardröjande problem med dansk dominans och den danska kulturella hegemoni som har rått och fortfarande i vissa delar råder inom grönländsk dansk-grönländsk forskningspolitik och samhällsforskning. Såväl ekonomiskt som kunskapsmässigt är landet starkt beroende av utländska forskare, företrädesvis från Danmark, även om en inhemsk forskarutbildning har initierats och är under uppbyggnad. De forskningsproblem som Kahlig lyfter fram är därmed nära relaterade till vad han beskriver som att "[f]orskningspolitik og samfundsforskning i Grønland var og er kendetegnet ved dansk kulturelt hegemoni og modelmagt.” (2003, 242). En ofta förekommande eurocentrisk tyngdpunkt i synsätt, val av studieobjekt och analysmetoder bidrar enligt Kahlig till missvisande tolkningsramar och slutsatser och med konflikter och missförstånd mellan grönlänningar och utländska forskare som följd.

I Färöarna finns ett universitet och ett center för regional och lokal utveckling. Det senare är en organisation samfinansierad av det färöiska hemstyret och ett antal färöiska kommuner. Till det kan läggas en viss finansiering från privata intressenter. De projekt som finns redovisade för centret är i huvudsak studier av färöiska småföretags förutsättningar och handlingsstrategier, kommunal utveckling och kommunalt samarbete samt studier av ungdomars förutsättningar i perifera områden. Arbetet sker i samarbete med ett flertal nordiska institutioner. Enligt Färöarnas statistiska årsbok från 2004 ges offentligt ekonomiskt stöd till Färöarnas universitet framförallt till vad man betecknar som ekonomisk forskning (Árbók fyri Føroyar 2004, tabell 13.4, Hagstova Føroya 2004). Troligtvis ska innebörden av begreppet ekonomisk forskning förstås mycket brett. Som en indikation på det kan nämnas att det, enligt Färöarnas statistiska årsbok från 2004, är det enda område som erhåller statlig finansiering. Huruvida ekonomiska omfördelningar sker mellan olika administrativa och akademiska ämnesområden framgår ej och det är inte möjligt att inom ramen för detta arbete studera gränsdragningar mellan vad som definieras som ekonomisk forskning jämfört med annan forskning. År 2002 tillägnades forskning och utveckling 27 miljoner DKK av de totala utbildningsanslagen på 758 miljoner DKK. Den senare summan innefattar såväl grundutbildning som tertiär utbildning. I stort utgjorde kostnader för utbildning knappt 15 procent av Färöarnas offentliga utgifter år 2002 
(Árbók fyri Føroyar 2004, tabell 13.4, 202-203, 2004). Av den forskning som bland annat bedrivs vid Färöarnas universitet, och som är av betydelse i detta sammanhang, kan nämnas studier i kulturella förändringsprocesser, studier av politiska partier och politisk kultur, studier i företagsstrategier samt projekt kring den färöiska arbetsmarknadspolitiken ur ett jämförande perspektiv (se http://www.region.fo/UK/research_projects. html, http://www.setur.fo/).

År 1999 utgjordes de statliga anslagen till forskning och utveckling 2,32 procent av Islands bruttonationalprodukt, det vill säga något mer pengar per capita än Danmark och Norge men mindre än Sverige och Finland. ${ }^{2}$ Till skillnad från Sverige och Finland, där omkring 70 procent av anslagen avser företagssektorn tilldelar Island denna sektor knappt 50 procent (Nordic Statistical Yearbook 2003, 238-240). Istället avsätter Island omkring 50 procent av det ekonomiska stödet till forskning genomförd av aktörer inom den offentliga sektorn, omkring 20 procent av detta går till universitet och högskolor. Jämfört med östra Norden satsar Island relativt stor andel av de statliga anslagen för forskning och utveckling, 38,8 procent, på samhällsvetenskaplig forskning. ${ }^{3}$ I Island förekommer ett flertal studier vid olika forskningsinstitut och universitet kring olika aspekter på välfärdspolitiska frågor och välfärd. De som framträder tydligast är projekt med anknytning till olika segregeringsmekanismers könsmässiga aspekter. I den mån resultat från de olika områdena finns publicerade på skandinaviska eller engelska återfinns referenser till dem i föreliggande text.

\section{Etiska spörsmål}

Förutom statliga anslag är nordisk forskning generellt sett beroende av inkomster från stiftelser och fonder samt av bidrag från privata organisationer. Självfallet hamnar viktiga forskningsetiska spörsmål i fokus när anslagsgivare uttrycker specifika intressen och motiv bakom finansieringen och i diskussioner där insamlande och bevarande av information om individer kommer på tal, särskilt i jämförelsevis små och avgränsade

\footnotetext{
${ }^{2}$ Samma år utgjorde de statliga anslagen i de övriga nordiska länderna följande andelar; Danmark 2, 09 \%, Finland 3,22 \%, Norge 1,65 \% och Sverige 3,78 \% (Nordic Statistical Yearbook 2003, 239, tabell 143).

${ }^{3}$ Danmark 11, 2 \%, Finland 5,6 \%, Norge 7,1 \% och Sverige 5,6 \% (Nordic Statistical Yearbook 2003, 242, tabell 146).
} 
samhällen som de västnordiska. Det handlar om att följa de etiska koder som utarbetats och används för forskning inom en mängd olika forskningsfält i övriga Norden och i världen i stort. Ett ytterligare etiskt spörsmål med störst relevans för Grönland, där andelen utländska, företrädesvis danska, forskare är högst, gäller de konflikter som kan uppstå när till exempel ett samhälle som befinner sig i en postkolonial fas studeras utifrån ett mer eller mindre omedvetet eurocentriskt eller modernistiskt influerat perspektiv (Kahlig 2003). Det har inte varit möjligt att inom ramen för detta arbete avgöra om och i vilken utsträckning insamling respektive avsaknad av offentlig statistik inom olika välfärdspolitiskt relevanta områden i något av de västnordiska länderna är politiskt dirigerad eller utgör mer oberoende inlägg $i$ en indirekt dialog med styrande grupper inom respektive land eller, för Färöarnas och Grönlands del, i relation till danska myndigheter och politisk ansvariga. Liksom för vissa delar av östra Norden har det också varit svårt att uppskatta betydelsen av till exempel lönearbete i relation till andra försörjningsmöjligheter knutna till grad av självhushållning, inkomst via försäljning eller utbyte av varor och tjänster på en mer lokal marknad.

Även om befolkningarna i Färöarna och Grönland är små och en viss oro för att individers integritet kan skadas är befogad, talar mycket för att det är fullt möjligt att på ett hänsynsfullt och etiskt försvarbart sätt utnyttja redan befintlig statistisk information och bygga upp mer omfattande och detaljerade databaser kring levnadsnivå och andra välfärdsindikatorer utan risk för att individers integritet skadas eller att andra typer av informationsmissbruk sker. När det gäller välfärd mätt i hälsa och tillgång till olika typer av vård är förfogandet över registerdata från sjukvården en möjlig väg att bygga vidare på. För närvarande kan dessa databaser, på grund av urvalsstorleken, framförallt ge information om relativt vanligt förekommande sjukdomsförekomster, typer av sjukvårdsbesök etcetera. För mindre urvalsgrupper ställer skillnader i omfattning och i datainsamlingsmetoder till metodologiska problem (Health Statistics in the Nordic Countries 2002, 193). Ett synkront genomtänkt statistiskt underlag kan gynna såväl politiska och ekonomiska aktörer och administratörer som forskning inom en mängd olika områden.

I det följande sammanfattas kort mer allmän information om Färöarna, Grönland och Island som självstyrande och självständiga länder. Därefter följer en presentation av de gällande socialförsäkringssystemen, dess 
utformning och ersättningsnivåer. Innebörden och eventuella effekter på olika befolkningsgrupper och de följder de kan antas ha synliggörs delvis i de offentliga nationella statistiska materialen. För att exemplifiera och understryka behovet av vidare forskning har jag slutligen lyft fram några välfärdspolitiska aspekter av intresse för vidare forskning. 
28 Välfärdspolitiska förhållanden i Västnorden - Färöarna Grönland och Island 


\section{Allmänt om Färöarna, Grönland och Island}

På många sätt uppvisar Färöarna, Grönland och Island liknande socioekonomiska, demografiska, försörjnings- och förvärvsmässiga särdrag som är karaktäristiska för andra isolerade och sparsamt befolkade områden i Norden och övriga västvärlden. Geografiskt och befolkningsmässigt utgör ändå Grönland ett extremt exempel med sin stora yta, sparsamma kommunikationsmöjligheter och knappa befolkning utspridd längs kusterna. Befolkningsmässigt är Island fler gånger större än de övriga två. Liknande politiska utmaningar som kraftigt fluktuerande ekonomiska förutsättningar i kombination med tillbakagång av traditionella försörjningsmetoder och utkomster framhävs. Politiskt ställs länderna inför arbetet att reducera växande offentliga utgifter genom att motarbeta tendenser till ökande bidragsberoende bland vissa befolkningsgrupper kombinerat med hanteringen av ett sviktande entreprenörsskap, och därmed även arbetsmarknad, i en del geografiska områden. Samtidigt växer kraven på ökad offentlig finansiering inom andra områden. Men, som kommer att framgå tydligare längre ned, är de tre ländernas ekonomiska, politiska och sstrukturella förutsättningar mycket olika. De offentliga utgifterna för social trygget i Västnorden har stigit något under 1990-talet, ett faktum som tillskrivs just effekter av fluktuationer på arbetsmarknaden, åldrande befolkningar, utbyggnad av barnomsorg och vårdsektor samt växande politiska ambitioner att introducera förebyggande åtgärder i frågor som folkhälsa och sundhetsväsen, utbildningssystem samt omstruktureringar på arbetsmarknaden. Fortfarande utgör dock de sociala utgifternas ${ }^{4}$ andel av de västnordiska ländernas bruttonationalprodukter en betydligt mindre

\footnotetext{
${ }^{4}$ Med social utgift avses stöd till familjer och barn, arbetslöshet, sjukdom, ålderdom, handikapp, efterlevande och bostäder (Nordic Statistical Yearbook 2003, 108-115).
} 
del än vad som är fallet i de övriga nordiska länderna och i flertalet västeuropeiska länder ${ }^{5}$ (Social Protection in the Nordic Countries 2002). En delförklaring till de lägre sociala utgifterna kan vara demografisk. Färöarna, Grönland och Island har unga befolkningar och därmed ett relativt lågt antal äldre och både Färöarna och Island har lägre arbetslöshet än länderna i östra Norden.

Tabell 1 Sociala utgifter i procent av BNP

\begin{tabular}{cccc}
\hline Färöarna & Grönland & Island & Övriga Norden \\
\hline $21 \%^{6}$ & $19 \%^{7}$ & $20 \%^{8}$ & $27 \%^{9}$ \\
\hline
\end{tabular}

Källa: se respektive fotnot.

Det bör ändå påpekas att uppgifterna för storleken på sociala utgifter i relation till ländernas bruttonationalprodukter är lite osäkra eftersom de är hämtade eller kalkylerade utifrån ländernas offentliga statistik och beräkningsgrunderna för olika poster sannolikt skiljer sig åt.

\subsection{Självständighet och hemstyre}

Gemensamt för Grönland, Färöarna och Island är, förutom ländernas stora beroende av fiskerinäringar, att de räknas till världens mikrostater, det vill säga tillhör en grupp stater med färre än en miljon invånare (FNs definition). Island, som tidigare tillhörde Danmark, är en självständig stat med omkring 290000 invånare. Både Grönland (ca 56000 invånare) och Färöarna (ca 48000 invånare) ingår fortfarande i det danska riket. Färöarna har hemstyre sedan 1948 och Grönland sedan 1979. Båda är därmed unde-

\footnotetext{
${ }^{5}$ Snarare ligger ländernas utgifter i nivå med Irland (14,6 \%), Luxemburg (21,2 \%) och Spanien (20,0 \%). Flertalet övriga västeuropeiska länder har utgifter över 27 \% av BNP (Social Protection in the Nordic Countries 2002, tabell 4.1, 186).

${ }^{6}$ Enligt uppgift från Petra Joensen, Almannastovan, Färöarna 2005-02-06. En egen beräkning av BNP och uppgift för sociala utgifter år 2002, tabell 15.1 GNP och sociala utgifter tabell 13.4, sid 204 ger en något lägre andel på ca $17 \%$. Det beror sannolikt på att ytterligare utgifter tillkommer via kommuner och arbetsmarknadens parter. Árbók fyri Føroyar 2004. Hagstova: Torshavn.

${ }^{7}$ År 2001. Egen beräkning av uppgifter i Greenland in Figures 2003. Statistics Greenland.

${ }^{8}$ Uppgift för 2001. Social Protection in the Nordic Countries 2002. Social Expenditure Tabell 10.1, 186.

${ }^{9}$ Egen beräkning av tabell 4.1, 186, genomsnitt av utgifter för Danmark, Finland, Norge och Sverige (Social Protection in the Nordic Countries 2002).
} 
rordnade Danmark i frågor som rör utrikes- och försvarspolitik, rättsväsende, myntväsende samt, för Grönlands vidkommande, administration av icke förnybara naturtillgångar. Med vissa skillnader i innebörden av det färöiska respektive det grönländska hemstyret medges Färöarna och Grönland betydande politisk och ekonomisk autonomi med egen beskattningsrätt av befolkningarna. Till viss del Färöarna, men särskilt Grönland befinner sig i en ganska nyinledd fas av nationsbyggande samtidigt som de koloniala och postkoloniala bindningarna till de nordiska länderna, och då i huvudsak till Danmark, fortfarande upprätthålls. Inom båda dessa landområden är självstyre med nationell självständighet ett politiskt mål. Attityderna till att helt avsäga sig danskt politiskt och ekonomiskt stöd är dock splittrade mellan politiska partier och bland befolkningarna inom de båda hemstyrena. Till del har oenigheten att göra med tveksamheter inför att helt avsäga sig dansk överhöghet och därmed också danskt finansiellt stöd.

Enligt Lyck (1997a, 1997b) är den juridiska innebörden av hemstyre inte helt klar eftersom det varken skyddas av internationella fördrag eller i den danska konstitutionen. Sedan 1980-talet är de danska ekonomiska bidragen till Färöarna och Grönland huvudsakligen baserade på blockstöd, det vill säga ekonomiska transfereringar från Danmark, och de färöiska och grönländska ekonomierna är knutna till den danska kronan. Övergången till blockstöd kan på sätt och vis betraktas som en dansk bekräftelse på att Färöarna och Grönland ingår i det danska territoriet, parallellt med landets övriga regioner, men med långt mer omfattande själbestämmanderätt (Lyck 1997a, Lytthans 1999, Adolphsen och Greiffenberg 1999). De allmänt växande kraven på ökad regional och lokal autonomi och decentralisering av tidigare centralstyrda statliga ansvarsområden ligger i linje med införandet av blockstödet i Färöarna och Grönland. Blockstödet utgörs av fastlagda summor och utgår från en dansk uppskattning av de egna kostnaderna för den offentliga administrationen av färöiska och grönländska ärenden i Danmark. När det gäller sociala utgifter överför alltså Danmark en summa motsvarande kostnaderna för den egna administrationen till de färöiska och grönländska myndigheterna mot att man i Färöarna och Grönland själva tar över och organiserar de offentliga åtagandena och utgifterna efter egna behov och förutsättningar. Enligt Lyck (1997a, 122ff) innebär denna typ av transferering att en förskjutning skett från att tidigare ha inneburit en överföring av öronmärkta danska tjänster till Färöarna och Grönland till att ha kom- 
mit att utvecklas till att Danmark, genom att överföra en klumpsumma till hemstyrena, stödjer regionalt självstyre och utvecklandet av lokala organisationer utan att detaljstyra dessa eller de sätt på vilka de väljer att genomföra sina åtaganden.

Särskilt Grönland är i mycket hög grad beroende av ekonomiska transfereringar från Danmark. Under 2002 utgjorde det danska blockstödet knappt 40 procent av den grönländska bruttonationalprodukten. Det danska ekonomiska stödet till Färöarna utgör ungefär 15 procent, och därmed en långt mindre del, av Färöarnas bruttonationalprodukt. Den stora skillnaden beror på att avtalen med Danmark om hemstyre ser något olika ut för Färöarna och Grönland. Sedan mitten av 1970-talet har Färöarna bit för bit övertagit delar av administrationen för bland annat socialtjänsten och därmed avsagt sig danskt ekonomiskt stöd. Sedan 2001 har Färöarna att själva helt ansvara för stora delar av den sociala omsorgen, såväl administrativt som ekonomiskt (Joensen 2004). Varken Färöarna, Grönland ${ }^{10}$ eller Island är medlemmar i EU. Island är dock medlem i the European Economic Area (EEA). Grönland och Färöarna har istället slutit fiskeriavtal med EU. Grönland inbringar på så sätt ett värde motsvarande 320 millioner danska kronor via olika avtal med EU gällande fiskekvoter och därutöver en del fördelar i samband med en uppgörelse om tullfrihet för varor från EUs marknader (Näslund 2000).

\subsection{Basnäringar, nya näringsgrenar, arbete och migration}

Enligt Jónsson (1995) har Färöarna, Grönland och Island tidigare på olika sätt drivits av ekonomiska lagstiftningar till stöd för de inhemska befolkningarnas ekonomiska utkomst och för bevarandet av nationella kulturella värden. Samtidigt har centraliseringen av kapital fram till 1990-talet varit stor i både Grönland och Färöarna (Jónsson 1995). Förändringar i omvärlden så som Sovjetunionens fall och EUs utveckling mot en ökad ekonomisk och politisk integration har både lett till tilltagande nationella och internationella befolkningsrörelser och till förstärkningar av de övriga nordiska ländernas fokus på den inre europeiska markanden. En konsekvens av detta är att redan perifera områden tenderar att ytterligare mar-

\footnotetext{
${ }^{10}$ Före införandet av hemstyre var Grönland, som dansk region, sedan 1973 medlem i EEG men fick som första och enda land hittills tillstånd att avsäga sig medlemskapet 1983 (Lyck 1997a, 134).
} 
ginaliseras. De nationella arbetsmarknaderna i Färöarna, Grönland och Island påverkas på flera sätt av förhållanden mellan vad man skulle kunna beteckna som centrum och periferi inom de tre länderna men också av respektive lands relation till framförallt Danmark (i Färöarnas och Grönlands fall) och övriga Norden och till Europa och Nordamerika. Den eskalerade rationaliseringen och stordriftstänkandet inom fiskeindustrin under 1980-talet utmynnade i slutet av 1980-talet och början av 1990talet i ekonomiska kriser och ytterligare strukturrationaliseringar (Jónsson 1995). Den känsliga balansen mellan huvudnäringen och vikten av ökad marin kunskap tydliggjordes samtidigt som behovet av mer diversifierade ekonomiska strukturer och arbetsmarknader blev uppenbar (OECD 1999, Apostle et al 2002, Knudsen 2003). Vissa sociala, ekonomiska och rumsmässiga omstruktureringar har skett med förskjutningar av ekonomiska centra till följd. För Färöarnas del understryker Hovgaard (2002) behoven av ett ökat och mer kontinuerligt samarbete mellan nationella, regionala och lokala politiska organ för att påverka utvecklingen mot en mer diversifierad, och därmed mindre kriskänslig, regional och lokal arbetsmarknad.

Till skillnad från Färöarna och Island där privatägda småföretag har varit den vanligaste företagsformen har ägandeförhållandena i Grönland dominerats av offentligt ägda större bolag. Grönlänningarna har dessutom i vissa delar fler gemensamma drag med Canadas och Alaskas urbefolkningar än med övriga nordiska befolkningar. Som en följd av 1990-talets krislösningar har stora delar av Färöarnas finans- och fiskerisektor övergått i offentligt ägande och idag är återprivatiseringar inom dessa sektorer ständigt aktuella i politiska och ekonomiska diskussioner. Ekonomin i Västnorden beror nästan helt av exportinkomster från fiskerinäringen som till största delen består av fiskerier och fiskerelaterad industri och arbetsmarknaden i de tre länderna utgörs till drygt tio procent av arbetsplatser inom fiskerinäringen. Under de senaste tio till femton åren har tjänstesektorn gjort sig gällande som den mest expansiva arbetsmarknaden. I servicesektorn ingår arbetstillfällen inom offentlig administration, vård, omsorg och utbildning, en framväxande privatkonsumtions- och servicesektor samt en mer kunskapsbaserad och högteknologisk tjänstesektor. I tabell 2 presenteras den västnordiska förvärvsfrekvensen och dess fördelning över de största näringsgrenarna. 
Tabell 2 Förvärvsfrekvens och fördelning över de största näringsgrenarna i Västnorden.

\begin{tabular}{|c|c|c|c|c|c|c|}
\hline & \multicolumn{2}{|c|}{ Färöarna } & \multicolumn{2}{|c|}{ Grönland } & \multicolumn{2}{|c|}{ Island } \\
\hline & Kvinnor & Män & Kvinnor & Män & Kvinnor & Män \\
\hline Förvärvsfrekvens & $75 \%^{11}$ & $91 \%$ & $\begin{array}{l}84.2 \\
\%^{12}\end{array}$ & $81.9 \%$ & $76 \%{ }^{13}$ & $84.2 \%$ \\
\hline $\begin{array}{l}\text { Varav inom jordbruk, } \\
\text { skogsbruk, jakt, fiske och } \\
\text { fiskeindustri }\end{array}$ & $1.5 \%{ }^{14}$ & $21.5 \%$ & \multicolumn{2}{|c|}{$17.3 \%{ }^{15}$} & $7.8 \%{ }^{16}$ & $14.5 \%$ \\
\hline $\begin{array}{l}\text { Varav inom privat och } \\
\text { offentlig service }\end{array}$ & $72.9 \%{ }^{17}$ & $41.8 \%$ & 60 & & $85.2 \%^{19}$ & $55.9 \%$ \\
\hline Andel arbetslösa & $4 \%^{20}$ & $2 \%$ & $5.9 \%{ }^{21}$ & $6.9 \%$ & $2 \%^{22}$ & $3 \%$ \\
\hline $\begin{array}{l}\text { Genomsnittlig årsinkomst } \\
2002 \text { i Euro }\end{array}$ & $8850^{23}$ & 26500 & \multicolumn{2}{|c|}{$22900^{24}$} & $19870^{25}$ & 31720 \\
\hline
\end{tabular}

${ }^{11}$ OBS! Färöarna har för närvarande ingen statistik över arbetskraftstalen utan kan endast redovisa uppgifter över antalet arbetslösa med arbetslöshetsersättning eller socialbidrag. På begäran har Hagstova gett mig följande beräkning utifrån antal personer i förvärvsarbete i åldergruppen 15-69 år 2003. Åldergruppen är något missvisande eftersom pensionsåldern i Färöarna är 67 år.

${ }^{12}$ Andel på arbetsmarknaden 2002. Greenland in Figures 2003, 10, Statistics Greenland 2003.

${ }^{13}$ Labour market statistics, table 2.1.2, Statistics Iceland 2002. http://www.statice.is/ ?pageID=788.

${ }^{14}$ Förmodligen är siffrorna för Färöarna något högre, särskilt för kvinnor, eftersom de ovan angivna procenttalen inte inkluderar anställda inom fiskförädlingsindustrin vilken till stor del utnyttjar kvinnlig arbetskraft. Tabell 81, sid 158. Nordic Statistical Yearbook 2003.

${ }^{15}$ Ingen uppdelning av kvinnor och män görs. Egen beräkning av tabell sid 11. Greenland in Figures 2003. Statistics Greenland 2003.

${ }^{16}$ År 2002. Iceland in Figures 2003-2004. Statistics Iceland 2003.

${ }^{17}$ Beräkning av uppgifter i tabell 81, sid 158. Nordic Statistical Yearbook 2003. I beräkningen ingår anställda inom handel, hotell- restaurang, ekonomi, försäkring, fastighets- och affärstjänster samt servicesektor.

${ }^{18}$. Ungefärliga siffror. Ingen uppdelning av kvinnor och män görs. Egen beräkning av tabell sid 11. Greenland in Figures 2003. Statistics Greenland

${ }^{19}$ År 2002. Iceland in Figures 2003-2004. Statistics Iceland 2003.

${ }^{20}$ År 1999 (Sid 3, Statistical Bullentin 2000 of the Faroe Islands, Hagstova).

${ }^{21}$ Andel arbetslösa 2002. Greenland in Figures 2003, Statistics Greenland 2003.

${ }^{22}$ Arbetslöshet 2002, tabell 79 (Social Protection in the Nordic Countries 2002,73).

${ }^{23}$ Beräknat på uppgifter om genomsnittlig timlön 2002 samt på arbetsgivares uppgifter om utgifter för lönekostnader fördelade över kvinnor respektive män (Hagstova 2004). Utan att ha studerat frågan mer i detalj har resultatet av de kalkylerade uppgifterna preliminärt bekräftats av en tjänsteman på Hagstova 2004-10-07.

${ }^{24}$ Inkomst beräknad som ett genomsnitt av inkomster för födda i och utanför Grönland på hushållsnivå. Eventuella barns inkomster är ej inkluderade. (Indkomststatistik 1992-2002. Del 2, tabell 2.1, 18. Statistics Greenland 2004:1. http://www.statgreen.gl/. 2004-11-18). Viktigt att notera att de med högts inkomst, ensamstående födda utanför Grönland har en mer än dubbelt så hög årsinkomst som sammanboende par födda i Grönland. Sambeskattningen medför att gifta personers inkomst inte kan urskiljas individuellt.

${ }^{25}$ Uppgift för 2002, Tabell 14.6. Statistical Yearbook for Iceland 2003. Statistics Islands. 
Källa: se fotnoter

I Island och Färöarna är förvärvsfrekvensen bland både kvinnor och män idag lika hög eller högre än i östra Norden, de flesta arbetar heltid och arbetslösheten är lägre. ${ }^{26}$ Den kvinnliga förvärvsfrekvensen har stigit kraftigt sedan slutet av 1970-talet i samtliga tre länder. Enligt Mørkøre (1997b, 216) var år 1977 andelen förvärvsarbetande kvinnor i Färöarna 27 procent. Som framgår av tabell 2 är den idag drygt 70 procent. I Grönland utgjorde 1998 kvinnor 44 procent och män 56 procent av det totala antalet anställda. Samtidigt har andelen grönländska arbetstagare ökat i relation till andelen förvärvsarbetande som är utrikes födda. (Beskceftigelsen i Grønland 1998 (foreløbige tal) 2000:6, 8, Grønlands Statistik). Som framgår av tabellen nedan är kvinnor idag i majoritet på den grönländska arbetsmarknaden. Även i Island har förvärvsfrekvensen ökat och ligger idag på drygt 80 procent för män och något lägre för kvinnor (Labour market statistics, table 2.1.2, Statistics Iceland 2002). Omkring 17 procent av förvärvsarbetande islänningar har två förvärvsinkomster. Det finns ett ganska svagt samband mellan kön och att ha två inkomster, där män tenderar att dominera. Det är mest tydligt bland befolkningen på landsbygden (Labour Market Statistics 2002, tabell 2.5.2, Statistics Iceland 2002). Mönstret för mäns och kvinnors arbetsmarkandsdeltagande i Västnorden påminner om det i övriga Norden. Bland deltidsarbetande är kvinnor i tydlig majoritet. Män är oftare anställda inom den privata sektorn och kvinnor återfinns oftare inom offentlig sektor. För Grönlands del tillkommer ett ytterligare könssegregerat mönster; bland löntagare med dansk arbetsgivare utgör män 75 procent (Beskeftigelsen i Grønland 1998 (foreløbige tal) 2000:6, 8, Grønlands Statistik).

Även om andelen personer i de västnordiska områdena som arbetar inom jordbruk, jakt och fiske är dubbelt så stor som i östra Norden arbetar ändå flertalet idag inom olika privata och offentliga serviceyrken. Differensen i data utgörs i huvudsak av personer inom andra näringsgrenar så som gruvdrift, tillverkningsindustri eller energiframställning. När det gäller de kalkylerade ungefärliga årsinkomsterna är de förmodligen inte helt rättvisande. De är beräknade som en uppskattad årsinkomst för en heltidsarbetande person utifrån nationella statistiska uppgifter om timlö-

\footnotetext{
${ }^{26}$ Den genomsnittliga förvärvsfrekvensen i östra Norden låg år 2002 på omkring 74 procent, högst i Norge och lägst i Finland. Arbetslösheten i de östnordiska länderna var samtidigt något högre än i Färöarna och Island (Nordic Statistical Yearbook 2003 tabell 77, 154 och tabell 78, 155).
} 
ner och lönekostnader. I den mån det varit möjligt har beräkningar gjorts för män och kvinnor. För Grönlands del är en sådan uppdelning inte möjlig eftersom inkomst redovisas på hushållsnivå och därmed kan innefatta fler än en inkomst. Huvudsyftet med att presentera inkomstuppgifterna är att visa på de stora löneskillnaderna mellan kvinnor och män. Eftersom lika lön för lika arbete är en gällande regel även i Västnorden reser inkomstskillnaderna frågor kring om löneskillnaderna är ett resultat av kvinnors högre andel i deltidsarbete, om detta i sin tur eventuellt indikerar en könsbaserad struktur av en betydande grad av undersysselsättning bland kvinnor eller om män de facto har betydligt högre löner men befinner sig inom yrkesgrupper eller positioner där kvinnor mer sällan är representerade.

Det förekommer en del inomnationella skillnaderna i arbetslöshet och inkomster. Dessa kan antas vara nära förbundna med sysselsättningsgrad, utbildningsnivå, bostadsort och för Grönlands del även med etnicitet (se Sigurdsteinsdottir 2003, Beskjæftigelsen i Grønland 2002). När det gäller personers utbildningsval finns det tecken som tyder på att anställningsmöjligheter betraktas som mer lovande inom tjänstesektorn (Greenland in Figures 2003, Faroe Islands in Figures 2003) och i varje fall när det gäller Island är koncentration av personer med akademisk utbildning högre inom offentlig sektor och handel än inom råvaru- och tillverkningsindustri (Edvardsson 2001). Jag återkommer till utbildningsfrågan i nästa avsnitt.

Orsaken till fiskerinäringens minskade arbetsmarknadspolitiska betydelse kan delvis härledas till nya internationella regleringar av fiskerättigheter, vilket är särskilt tydligt för Färöarna, konkurser och stora rationaliserings- och omstruktureringseffekter efter 1990-talets kris, minskad tillgång av fisk och en växande tjänstesektor. Med början i fiskeindustrin fick 1990-talets ekonomiska kris mycket stora effekter på de västnordiska samhällena. Rationaliseringar inom fiskeindustrin medförde att andelen anställda inom näringsgrenen sjönk kraftigt och ett stort antal människor friställdes. Detta kom att innebära stora belastningar på de politiska och ekonomiska systemen och på enskilda individer. Bland annat som en följd av den sviktande arbetsmarknaden har människor valt att migrera internt och till andra länder. Migrationsströmmarna har varit särskilt stora från Färöarna. Mellan 1990 och 1995 minskade Färöarnas befolkning med 
omkring $10 \%$, Grönlands något mindre. ${ }^{27}$ Befolkningarna har sedan slutet av 1990-talet ökat igen och i Färöarna överskrider de idag befolkningssiffror från tidigt 1990-tal. Det är oklart om det handlar om återflyttning eller om det är nya grupper som migrerar till dessa områden. Den socioekonomiska sammansättningen av de grupper som migrerar är diffus men av den nationella befolkningsstatistiken kan uttolkas att underskottet bland kvinnor i arbetsför ålder är särskilt tydligt i Grönland och, om än i något mindre utsträckning, även i Färöarna. Av de totala befolkningarna utgör kvinnor idag ungefär $48 \%$ av den färöiska befolkningen och knappt $47 \%$ av den grönländska ${ }^{28}$. Som en förklaring till det grönländska kvinnounderskotten kan nämnas att immigration av danska byggnadsarbetare är omfattande och möjligen förskjuts statistiken så att befolkningen i åldergruppen 20-50 år kommit att domineras av män. Det betyder således att kvinnounderskottet inte i första hand handlar om grönländska kvinnors emmigration utan snarare om en betydande manlig arbetskraftsinvandring.

De interna migrationsströmmarna i Västnorden har också ökat markant och också inom dessa grupper är det kvinnor som utgör den största andelen (Edvardsson 2001, Helve et al 2002, Greenland 2001-2002. Statistical Yearbook). Även om migration inte är någon sentida företeelse utan pågår mer eller mindre intensivt under olika tidsperioder understryker befolkningsstatistiken behovet av att närmare analysera den socioekonomiska betydelsen av och sambandet mellan kön, utbildning och flyttmönster. Gemensamt för de tre områdena tycks vara att unga kvinnor oftare lämnar perifera områden för arbetstillfällen eller vidareutbildning och tenderar att inte återvända. De unga männen som stannar riskerar att fastna i arbetsmarknadsrelaterade strukturella inlåsningsfällor (Hovgaard 2002, Helve et al 2003). Trots en ofta positiv bild av hemorten bland ungdomar är bristen på arbete den starkaste anledningen till utflyttning och svårigheter att återvända. Enligt Firouz Gaini, ungdomsforskare i Färöarna, analyseras eller diskuteras sällan ungdomar som en specifik social kategori eftersom de förväntas gå rakt in i vuxenlivet efter avslutad skola (2003). Gaini påpekar dock att 1990-talets ekonomiska kris har satt djupa spår i ungdomars sociala och ekonomiska kapital och att många därmed befinner sig i en situation som skiljer sig från tidigare generatio-

\footnotetext{
${ }^{27}$ Nordic Statistical Yearbook 2003.

${ }^{28}$ År 2003. Nordic Statistical Yearbook 2003, sid 77.
} 
ners. Gaini menar att krav på social konformitet, svårigheter att finna arbete och/eller insikten om förändrade behov av utbildning gör att många ungdomar söker sig till Torshavn eller till Danmark för arbete eller studier.

I Island innebar nittiotalskrisen en minskning av arbetsplatser inom jordbruk, fiske och tillverkningsindustri och en kraftig ökning av arbetstillfällen inom servicesektorn (Edvardsson 2001). Av olika skäl, och till skillnad från Färöarna och Grönland, så som bättre förutsättningar att uppnå en mer varierad arbetsmarknad och tillgången till en självständig valuta, kunde Island hantera nittiotalets ekonomiska kris på ett sätt som inte ledde till stora utflyttningar. Den interna migrationen var ändå påtaglig och 1999 fanns 62 procent av arbetskraften i området kring Reykjavik (Edvardsson 2001). Migrationen till Island har ökat och isländska data visar att andelen utrikes födda har fördubblats under de senaste 10 åren, från totalt omkring 10000 personer 1993 till knappt 20000 år 2002 (Statistics Iceland. www.hagstofa.is). Mellan 2001 och 2002 ökade invandringen till Island med ca $38 \%$. Förutom återvändande islänningar sker invandringen företrädesvis från Polen samt från andra ickeskandinaviska EU-länder och från Asien, och då särskilt från Filippinerna och Thailand (Statistiscs and Information. www.ahus.is/FRAMES/ENG/ navig/stats.htm. 2003-03-31). Av statistiken framgår dock inte hur könsfördelningen inom dessa grupper ser ut eller vilka försörjningsmöjligheter immigranter söker. Efter stora ekonomiska omstruktureringar i näringslivet och nedskärningar i antalet arbetsplatser utgör fiskerinäringen fortfarande den absolut största exportvaran i alla tre länder.

\subsection{Västnordisk arbetsmarknad och arbetsmarknadspolitik}

Den arbetsmarknadspolitiska inriktningen i Västnorden har framförallt varit konstruerad som näringspolitik och riktats till privat näringsliv och till i huvudsak manligt dominerade förvärvsområden. Man har till exempel i Färöarna aldrig politiskt formulerat någon formell arbetsmarknadspolitik men i praktiken har det mycket starka ekonomiska och politiska stödet till den nationella fiskeindustrin haft som indirekt syfte att skapa arbetstillfällen och reducera arbetslöshet (Mørkøre 1997b). Arbetslöshet, migrationsrörelser mellan yrkessektorer och mellan länder 
har betraktats som nödvändiga och oundvikliga effekter av strukturomvandlingar. Det inledande antagandet att värderingsmässiga nordiska likheter när det gäller jämlikhet skulle medföra liknande syn på välfärdspolitik och välfärdspolitiska lösningar står delvis i kontrast till huvudlinjen i färöisk och isländsk politik. I likhet med Hannibalsson (2004), och i linje med Ólafssons (2004) beskrivning av den dominerande hållningen i isländsk politik, menar Mørkøre (1997b) att de färöiska självständighetsanspråken värderingsmässigt anses rimma illa med ett välfärdspolitiskt efterliknande av den nordiska modellen. Ett införande av den nordiska välfärdsmodellen med en aktiv arbetsmarknadspolitik kombinerad med ett omfattande socialförsäkringssystem uppfattas av delar av den färöiska befolkningen som ett hot mot traditionella värderingar kring individens personliga ansvar för sin utkomst och välfärd. En sådan politik antas reducera individens eget ansvar och uppmuntra till bidragsberoende, alternativt till konstruktionen av artificiella offentliga arbeten. Istället förordar Mørkøre en vidareutveckling av Färöarnas historiskt sett betydande internationella arbetsmarknad där människor med hjälp av progressiv och kvalitativt god utbildning förväntas söka sig bort från Färöarna och tillbaka igen, beroende på tillståndet och förutsättningarna i den lokala och den internationella arbetsmarknaden. Samtidigt finns inga egentliga uppgifter eller analyser av vare sig de reella västnordiska arbetsmarknaderna, inomnationella och internationella migrations- eller pendlingsmönster, vilka grupper de involverar eller den eventuella migrationspendlingens betydelse för arbetskraftens kvalifikationsnivå. Utifrån ett antal studier av lokala ledarskapsstrategier och lokala nätverk i Färöarna drar Hovgaard (2002, 121-122) bland annat slutsatsen att bristen på diversifierade lokala arbetsmarknader hindrar personer som vidareutbildat sig från att återvända till sina hemorter. Orsaken till denna brist härleder Hovgaard till den underordnade roll som politiska handlingsstrategier tillåtits spela och som inte sträcker sig bortom politiska insatser för akut "krishantering”. Med det avser Hovgaard att den politiska potentialen på lokal, regional och nationell nivå är starkt underutnyttjad och efterlyser en förstärkning av politiska insatser i syfte att etablera handlingsplaner inom områden som riktar sig mot ungdomsfrågor, utbildningsväsendet och välfärdspolitiska frågor. ${ }^{29}$

\footnotetext{
${ }^{29}$ Se också Hoovgard, Eythórsson och Fellman (2004).
} 
Den ekonomiska krisen under 1990-talet medförde på olika sätt stora påfrestningar på de västnordiska politiska systemen och Färöarna och Island införde eller reformerade arbetslöshetsförsäkringar alldeles i slutet av förra århundradet. År 1992 bildades ett grundläggande universellt finansiellt stöd för arbetslösa i Färöarna. Det är obligatoriskt och finansieras av arbetsmarknadens parter och administreras via skatt på förtjänad arbetsinkomst. Från att ha erbjudit en mycket begränsad arbetslöshetsersättning infördes i Island 1997 ett mer generöst system som även det finansieras med obligatoriska arbetsgivaravgifter via skattesystemet. I Grönland har en introduktion av en arbetslöshetsförsäkring övervägts men mot bakgrund av varningar från OECD $^{30}$ förblev man 2001 vid det befintliga arbetslöshetsunderstödet och med fortsatt strama behörighetskriterier. Gruppen bidragsberättigade utökades dock till att omfatta en större grupp arbetssökande än enbart anslutna till det grönländska fackförbundet SIK.

Behovet av att uppmuntra och stödja framväxten av andra parallella näringsgrenar i Grönland har understrukits (OECD 1999). Svårigheterna med att bygga upp sådana beror till stor del på de små och geografiskt spridda interna marknaderna och på den betydande ekonomiska osäkerheten relaterad till fiskerinäringens totala dominans och dess instabila förutsättningar (Jónsson 1999b). Mot bakgrund av det grönländska hemstyrets framträdande ekonomiska roll tar Winther (1999, 2004) och Jónsson (1999a) upp premisser för en utvecklad markandsekonomi i Grönland. Höga investerings- och transfereringskostnader, stora landytor samt en mycket begränsad och utspridd hemmamarknad innebär att privata investeringar i Grönland är att beteckna som högriskprojekt och både Jónsson (1999a) och Winther (1999) efterlyser studier kring i vilken utsträckning hemstyrets organisering och nära relation till Danmark utgjort hinder för tidigare försök att införa en marknadsekonomi och på

\footnotetext{
${ }^{30}$ OECD uppmanar till försiktighet och eftertanke inför grönländska planer på att införa en arbetslöshetsförsäkring och understryker vad man betraktar som tre stora risker. För det första skulle det innebära ökade offentliga utgifter eftersom OECD befarar att en arbetslöshetsförsäkring skulle kunna fungera som en drivfjäder för lågproduktiva personer att utnyttja arbetslöshetsersättning som ett försörjningssystem. För det andra befaras en arbetslöshetsförsäkring hota att utarma ett traditionellt levnadssätt i de mer isolerade bygderna utan att nya arbetstillfällen genereras som alternativ försörjningskälla. För det tredje bör en reform av socialförsäkringssystemen samordnas med förändringar i finansieringen av förtidspensioner för att minska kommunernas ekonomiska motivation att tilldela individer förtidspensioner (OECD 1999, (OECD 2000). OECDs uttalande baseras på kunskaper om europeiska arbetslöshetsförsäkringar och utgår inte från de grönländska förslag som övervägts.
} 
vilket sätt hemstyret har och kan komma att utgöra en grundläggande förutsättning för framtida investeringar. Jónsson diskuterar därutöver de inhemska socioekonomiska konsekvenserna av Grönlands beroende av den danska valutan och identifierar allvarliga konsekvenser av vad han kallar det grönländska "organisatoriska beroendet" av dansk ekonomi och administration som till stor del bygger på vad Jónsson kallar för "institutionell rasism”. Enligt Jónsson betecknar begreppet institutionell rasism de socialiseringsprocesser där ett "danocentriskt" administrativt, ekonomiskt, tekniskt och strategiskt tänkande innebär ett ständigt övervärderande av dansk kunskap och utbildning förvärvad i Danmark på bekostnad av inhemska personers erfarenheter och kunskapsbas (se också Jónsson 1999b). Även Kahlig (2003) diskuterar problemet med dansk dominans och den danska kulturella hegemoni som råder inom grönländsk forskningspolitik och samhällsforskning. De bidrar till konflikter och missförstånd mellan grönlänningar och danskar. ${ }^{31}$ Dessa typer av problem eller debatter förefaller inte vara aktuella när det gäller Färöarna.

Majoriteten av Grönlands befolkning är idag på något sätt involverade i lönearbete. Dock är arbetslösheten ganska hög, framförallt på landsbygden och relaterad till olika typer av deltids- eller säsongsanställningar (Greenland 2001-2002 tabell 12.2 och 12.4, Arbejdsmarked 2004:1, Arbejdsmarked 2005:2). Den begränsade grönländska arbetsmarknaden har på senare år lyfts fram som en politisk fråga med välfärdsstatliga implikationer. I en forskningsrapport från 2004 redogör Gorm Winther för ett pågående projekt inom vilket ett av syftena är att kartlägga den grönländska produktiviteten och relationer på arbetsmarknaden. Avsikten är att ta udden av etablerade föreställningar om den låga grönländska produktiviteten (OECD 1999), som det enligt Winther inte finns några empiriska belägg för, och presentera produktionsförhållanden och arbetskraftsdeltagande ur ett grönländskt perspektiv. Av projektrapporten framgår att frånvaron från arbetsplatser inte är högre än i övriga nordiska länder och att grönländska anställda i det hela taget är tillfredsställda med sina arbeten. Den rapporterade frånvaron har, enligt Winther, tre huvudsakliga orsaker. För det första spelar sociala och hälsomässiga problem som alkoholism, drogberoende och undernäring en viss betydelse. För det andra är arbetsplatsernas utformning, ledningsfunktioner och lönenivåer viktiga för att anställda ska uppfatta arbetet som meningsfullt och för det

\footnotetext{
${ }^{31}$ Se också Winther, G. 2003.
} 
tredje spelar det omgivande samhällets förmåga att uppmuntra till lönearbete en viktig roll. Om offentliga institutioner som till exempel barnomsorg och skolor inte kan garantera barnens välmåga och säkerhet har det klara negativa effekter på arbetslivet. Utstötning från arbetsmarknaden och olika effekter av marginalisering har därför allt mer kommit att uppmärksammas inom framförallt grönländsk samhällsekonomisk forskning och forskning kring folkhälsa (Strategi for dansk-grønlandsk polarforskning 2003-2007).

På senare tid har i Grönland ett utökat samband mellan marginaliseringseffekter, välfärd och förvärvsutveckling understrukits från politiskt håll. I den rapport som hemstyret presenterade i oktober $2003^{32}$ konstateras att en kraftig värdetillväxt i förvärvslivet är nödvändig för att Grönland ska kunna utveckla en oberoende och självförsörjande ekonomi med ett väl fungerande utbildningssystem, en utbyggnad av infrastrukturen och ett finmaskigt socialt säkerhetsnät. För att nå dessa mål krävs kraftfulla politiska åtaganden för att utöka andelen personer i arbete och via utbildningssystemet reducera andelen importerad arbetskraft. Incitamenten för att få människor i arbete ska på ett flertal olika sätt förstärkas med allt från politiska åtgärder för att reducera antalet bidragsberoende till arbete i syfte att förbättra psykisk och fysisk arbetsmiljö ${ }^{33}$. Företagen måste konkurrensutsättas så att innovativa lösningar och produkter, lönsamhet och avkastning blir ledstjärnor. Rapporten är upplagd som en blandning mellan konkret handbok och mer målinriktad utvecklingsplan för olika administrativa nivåer inom såväl det politiska systemet som inom organisationer för arbetsmarknadens parter. I samband med detta är Wolfgang Kahligs projekt Koordination af uddannelse- og erhvervsvejledning i Grønland...(2003-2005) av intresse. Projektet syftade till att utveckla en strategi för hur utbildnings- och yrkesvägledning bör koordineras för att undvika inlåsningseffekter, marginalisering och exklusion. Studien sker mot bakgrund av en tidigare undersökning av arbetssökande, framförallt män utan yrkesutbildning, som (av olika skäl) självvalt vandrar mellan arbete och arbetslöshet och därmed belastar såväl arbets-

\footnotetext{
${ }^{32}$ Rapporten (Uden Erhvervsudvikling - ingen Velfcerdsutvikling) är ett resultat av ett samarbete mellan Økonomi- og Erhvervsministeriet og Erhvervs- og Boligstyrelsen i Danmark samt Økonomidirektoratet og Direktoratet for Erhverv i Grønlands Hjemmestyre.

${ }^{33}$ Som problem relaterade till psykisk arbetsmiljö anges relationer mellan danskar och grönlänningar samt bristande ledarutbildning (Uden Erhvervsudvikling - ingen Velfcerdsutvikling, sid 23)
} 
förmedlingar som socialförsäkringssystemen. Projektet utgjorde ett delprojekt inom det mer omfattande projektet Faglig kompetence hos arbejdsstyrken $i$ Vestnorden (2003). Här genomfördes även vissa jämförelser med forskning och resultat från övriga Västnorden.

I kölvattnet från den senaste ekonomiska krisen har kriser för stordriftsproduktionen inom fiskerinäringen medfört att blickarna riktats mot småskaliga lösningar. I en studie från Färöarna visar Apostle et al (2002) en något mer nyanserad bild av hur nya och nygamla lokala - globala handelskedjor uppstått där vissa samhällen blomstrar upp medan andra, tidigare välbärgade områden riskerar att utarmas. Sammansättningen av lokala sociokulturella, politiska och ekonomiska nätverk, förmåga att hantera historiska erfarenheter kombinerat med kapaciteten att tolka nya förutsättningar och möjligheter samt en öppenhet inför innovativa lösningar kan, enligt författarna, vara det som skiljer ett lokalt färöiskt samhälle i förändring från ett stagnerande. ${ }^{34}$ Liknande händelseförlopp och erfarenheter kan iakttas även i Grönland och Island (Lyck 1997b, Hersoug 1997, Hovgaard 2001, Motzfeldt 2004, Knudsen 2003, Hovgaard, Eythórsson och Fellman 2004). En av de slutsatser som kan dras av dessa studier kring regional och lokal utveckling är att det, trots avsaknad av nationella regionalpolitiska riktlinjer i egentlig mening, ändå sker lokala ekonomiska och sociala omstruktureringar. Framförallt pekar Apostles et al (2002) studie på att kommunernas deltagande är av central betydelse för framgång, bland annat eftersom de med olika medel kan stödja olika mer långsiktiga och ekonomiskt riskfyllda projekt och fungera som institutionella garanter.

Författarna understyrker härigenom den avgörande betydelsen av lokala sociala kapital och vikten av konkreta sociala relationer i ekonomiska förändringsprocesser. Samarbetsformerna (vad författarna benämner som "coping strategies”35) återspeglar lokala varianter av tjänster och gentjänster kopplade till både administration och till det sociala kapital som tillförs via individers och intressegruppers förmåga att involvera och samarbeta med lokala politiska och ekonomiska aktörer och kommuner i förändringsarbetet. Rapporterna berör också det sätt på vilket nya och nygamla ekonomiska strategier påverkar samhällens socioekonomiska

\footnotetext{
${ }^{34}$ Se även hänvisningen till Hovgaards (2002) slutsatser som presenterats ovan.

${ }^{35}$ Begreppet "coping strategies” sett utifrån områden i den arktiska periferin har sedan 1996 utvecklats och använts inom MOST CCPP, circum polar coping processes projcects, vid universitetet i Tromsø (http://uit.no/mostccpp).
} 
strukturer. Bland de nya frågor som väcks i samband med de pågående lokala ekonomiska förändringarna finns spörsmål kring förekomsten av nya och nygamla politiska och ekonomiska maktstrukturer och hur tillit till dessa förstärks eller försvagas bland befolkningar i relation till tilltron till det centrala politiska styrets förmåga att agera inför samhällsekonomiska utmaningar. Ytterligare frågor som väcks berör de grupper som yrkesmässigt involveras i omstruktureringen av lokala ekonomier. Finner nya grupper av individer arbeten vid sidan av eller "på bekostnad" av tidigare arbetskraft? Om nya typer av arbetsuppgifter uppstår, ställer de andra krav på kompetens än tidigare? Hur omvärderas i så fall de klassoch könsmässiga hierarkierna i de västnordiska samhällena? Vi återkommer till dessa frågor längre fram men eftersom välfärd och försörjningsmöjligheter på många sätt också är knutna till hälsa och utbildning följer en kortfattad redogörelse för studier från dessa områden.

\subsection{Population, folkhälsa och utbildning}

Nativiteten i de tre länderna är, trots sjunkande siffror, fortfarande hög jämfört med övriga Norden och Europa. Överlag är befolkningsstrukturen "ung”, det vill säga, andelen äldre är mindre än i de flesta andra länder i västvärlden. Med ökad migration, stigande levnadsålder och sjunkande nativitet är detta dock ett förhållande som sakta håller på att förändras. ${ }^{36}$

Om man ser till tillgänglig hälsostatistik så är befolkningarna i Färöarna, Grönland och Island både friskare och sjukare än i övriga Norden.

\section{Folkhälsa}

Många sidor av folkhälsa och folkhälsorelaterade fenomen är nära knutna till sociala och ekonomiska ojämlikheter i befolkningar liksom även till aspekter av demokrati och olika gruppers möjligheter till inflytande på olika institutioner i det samhälle de lever och verkar. I samtliga nordiska länder är sundhetsväsendet ett offentligt ansvarsområde med väletablerad primärvård och förebyggande vård så som barn- och mödravård, skolhälsovård och tandläkarvård för barn och ungdomar. Vården finansieras med

\footnotetext{
${ }^{36}$ Mellan 1995 och 2003 har nativiteten har sjunkit något i Grönland och Island (Health Statistics in the Nordic Countries 2003, tabell 2.2,75).
} 
offentliga medel eller via obligatoriska sjukvårdsförsäkringar. I de flesta länder tas patientavgifter ut vid behandling och vid förskrivning av läkemedel. Variationer förekommer i grad av centralisering av hälsovården och i inslag av privatsjukvård.

I Health Statistics in the Nordic Countries 2002 (NOMESCO 2004) är endast vissa uppgifter från de västnordiska områdenas hälsostatistik inkluderade. På grund av bristande information och med hänvisning till de små befolkningarna menar författarna till rapporten att det är svårt att uttala sig om några länderspecifika skillnader eller likheter i hälsotillstånd förekommer. Generellt ökar välfärdsrelaterade sjukdomar som lungcancer, diabetes och sjukdomstillstånd relaterade till övervikt. I rapporten konstateras också att försäljningen av medicinska produkter är högst i Sverige och lägst i Island, Färöarna och Grönland. En fördjupad och mer detaljerad undersökning kring konsumtion och kostnader av medicinska produkter har inletts under 2004 (Health Statistics in the Nordic Countries 2002, 151-152). Frekvensen av olika typer av sjukdomar, sjukdomssymtom, och sjukdomstillstånd bör i ökad utsträckning studeras utifrån hur de sammanhänger med miljöfaktorer, livsstilar, levnadsvanor och levnadsvillkor. Liksom för övriga västvärlden visar grönländska och isländska forskningsresultat att det finns tydliga samband mellan hälsa och socioekonomiska bakgrund och att detta i stor utsträckning drabbar barn (Halldórsson et al 2000, Aaen-Larsen 2001, Berntsson and Köhler 2001, Freysteinsdóttir 2004, Guðmundsson 2004, Health Statistics in the Nordic Countries 2002). Fler och fördjupade jämförande analyser av sociala skillnader i hälsostatus skulle troligtvis kunna visa på skillnader och likheter mellan grupper inom och mellan länderna och i förhållande till övriga Norden och Europa. Miljömedicinska studier från Grönland visar att förekomster av miljögifter i traditionell kosthållning påverkar befolkningshälsan negativt. Behovet av att studera sambanden mellan livsstil, traditionell och mer västerländskt inspirerade matvanor och hälsa understryks (Inussuk. Arctic Research Journal 2000). ${ }^{37}$ Liknande effekter har observerats även i den färöiska befolkningen. ${ }^{38}$

När det gäller folkhälsa utgör Grönland i många avseenden ett väldigt speciellt fall. Ett område som uppmärksammas i flera rapporter och ar-

\footnotetext{
${ }^{37}$ Samtliga artiklar behandlar miljömedicinska aspekter av grönländsk kost och kostvanor.

${ }^{38}$ Se ett antal artiklar publicerade i International Journal of Circumpolar Health. http://ijch.oulu.fi/
} 
tiklar är behovet av studier av grönlänningars, och framförallt kvinnors och barns situation, dels utifrån ett hälso- och sjukvårdsperspektiv och dels utifrån frekvensen av familjerelaterat våld. I Grönland är förekomsten av tuberkulos och hjärnhinneinflammation (meningits) relativt hög medan antalet rapporterade fall av könssjukdomar som HIV, syfilis och gonorré sjunkit betydligt under 1990-talet (Greenland 2001-2002. Statistical Yearbook) men är fortfarande förhållandevis hög i jämförelse med övriga Västnorden och östra Norden. Antalet grönlänningar som utvecklar diabetes typ 2 utgör ett växande problem liksom det ökande antalet överviktiga, företrädesvis kvinnor (Politiken 2004-11-16). Trots kostnadsfria preventivmedel avbryts nära hälften av alla registrerade graviditeter med abort (Greenland 2001-2002. Statistical Yearbook) och det grönländska hemstyret har gett sitt hälsoministerium i uppdrag att reducera antalet aborter med 50 procent under en femårsperiod (Meldgaard 2003). Meldgaard beskriver problemet som multipelt och delvis relaterat till brister i hälsovårdspersonals samarbetsrutiner när det gäller samverkan över administrativa gränser och i förhållande till information till unga och vuxna medborgare. Den information, preventivmedelsrådgivning och preventivmedel som förmedlades riktas enbart till kvinnor. Som en ytterligare påverkansfaktor beskrivs olika former av kulturellt tryck som på flera sätt utövar stark press på unga kvinnor.

Spädbarnsdödligheten i Grönland är högst bland de nordiska och västnordiska länderna. I Färöarna och Island är den lägre än i övriga Norden (Health Statistics in the Nordic Countries 2003, tabell 2.6, 82). Spädbarnsdödligheten i Grönland och dödligheten bland äldre barn har visserligen sjunkit under 1990-talet men är ändå förhållandevis omfattande och, enligt Aaen-Larsen (2001), i nivå med utvecklingsländer i Sydasien. Den höga dödligheten bland spädbarn kan delvis relateras till brister i sjukvårdsväsendet men har också tydliga kopplingar till socioekonomiska faktorer som bostadsförhållanden, arbetslöshet, ekonomiska och sociala problem samt alkohol- och tobaksbruk. Bland grönländska barn i åldersgruppen 5-14 år, och där pojkar utgör den största andelen, uppges de främsta dödsorsakerna vara olyckor och självmord. Dödligheten skiftar mellan regioner och samvarierar med de socioekonomiska faktorerna (Aaen-Larsen 2001).

Enligt Sørensen (2001) visar ett flertal undersökningar att andelen kvinnor som utsätts för våld från närstående män i Grönland är åtskilliga 
gånger större än i Danmark. ${ }^{39}$ Inte sällan samvarierar familjerelaterat våld mot barn med våld mot kvinnor. Incest och våldtäkter utgör nära 13 procent av den rapporterade brottsligheten (Greenland 2001-2002. Statistical Yearbook) och under 2001 dömdes cirka 10 procent av grönländska män över 20 år för våld mot kvinnor (Poppel, M. 2004). Såväl våld mot kvinnor och barn som de vanligt förekommande aborterna visar på tydliga konsekvenser av starka könshierarkier, bestående mycket asymmetriska könsmaktsrelationer och, enligt Sørensen (2001), också på att våld mot kvinnor hanteras med stor politisk och administrativ ambivalens, både inom offentliga institutioner och av befolkningen. I Grönland kopplas våldet mot kvinnor till mäns socioekonomiska förhållanden och till sociala problem i vidare bemärkelse. Enligt Mariekathrine Poppel (2004) är lågutbildade och ofta arbetslösa män i 30-40-årsåldern överrepresenterade bland våldsutövarna och utöver arbetslöshet tenderar de att uppvisa multipla sociala problem. Resultaten står delvis i kontrast till undersökningar genomförda i östra Norden och som visar mycket små socioekonomiska skillnader bland våldsutövare och kvinnor som utsätts för könsrelaterat våld (Kön och våld i Norden 2002, Lundgren et al 2001, Lundgren 2004). Däremot återfinns i de östnordiska undersökningarna tecken som tyder på att våldet eskalerar när alkohol finns med i bilden och då oftare leder till uppsökande av sjukhusvård och polisanmälningar än under andra mer "kontrollerade" former för övergrepp.

För närvarande pågår flera omfattande projekt för att studera den grönländska befolkningens hälsa och sambandet mellan hälsa och andra yttre faktorer men Birger Poppel (2004) understryker vikten av att etablera en forskningsmässig datainsamling för att närmare kunna studera bland annat barns och kvinnors levnadsförhållanden samt att analysera de hälsomässiga effekterna av sociala och geografiska skillnader. Även här gäller alltså att såväl det grönländska välfärdssystemets utformning och effekter på olika befolkningsgrupper bör ligga i fokus för en analys. Här utgör också en studie om välfärdspolitiska institutioner, arbetsmarknaden

\footnotetext{
${ }^{39}$ När det gäller våld mot kvinnor har Färöarna ingen samlad statistik och ingen lagstiftning som specifikt förebygger eller skyddar kvinnor eller barn som utsätts för våld eller övergrepp i hemmet. Istället hänvisas till internationella konventioner kring mänskliga rättigheter (Reinert Planck 2004). Det finns enligt Reinert Planck heller ingen pågående forskning kring temat. I Tórshavn finns ett kvinnohus. Under 2003 inkom 273 förfrågningar om skyddsboende varav 13 accepterades (Árbók fyri Føroyar 2004, 253-254). För Islands del har jag inte funnit den information som sannolikt finns kring våld mot kvinnor.
} 
och av ansvarsrelationer mellan den danska staten, Grönlands hemstyre och dess lokala politiska enheter en viktig del.

\section{Utbildning}

Utbildningssystemen i Västnorden är uppbyggda efter en nordisk modell med obligatorisk grundskola, följd av praktiskt eller teoretiskt gymnasium och högskola eller universitet. Det är ändå inte alldeles lätt att jämföra utbildningssystemen, bland annat för att vad som betraktas som en gymnasial eller eftergymnasial utbildning varierar. Särskilt Färöarna och Grönland har på grund av sin befolkningsstorlek svårigheter att erbjuda något större bredd på högskoleutbildningar men erbjuder ett stort utbud av yrkesorienterade gymnasiala och eftergymnasiala utbildningar. Personer som vill skaffa sig en högre utbildning väljer ofta att flytta till något annat nordiskt land för fortsatta studier, företrädesvis Danmark. Danmark föredras även av isländska studenter som väljer en utländsk studieort. ${ }^{40}$ Liksom i övriga Norden kräver högskoleutbildning språkkunskaper, oftast i engelska, eftersom kurslitteratur och forskning av kostnadsskäl sällan översätts. För Grönland och Färöarna är dessutom kunskaper i det danska språket ett obligatoriskt skolämne. Även i Island ingår ytterligare ett nordiskt språk som obligatoriskt skolämne. I Grönland uppstår språkproblem redan i grundskolan eftersom undervisningen visserligen företrädesvis ska hållas på modersmålet men delar av undervisningslitteraturen är på danska. Marginaliseringsproblem på grund av språksvårigheter har uppmärksammats som en konsekvens av identitetspedagogiska och inlärningsmässiga problem (Langgård 2003). Den färöiska undervisningen sker på färöiska och med färöisk litteratur och det finns inga dokumenterade belägg för socioekonomiska effekter av just språkmässiga krav.

Kvinnor är i majoritet bland dem som väljer högskolestudier, ett mönster som återfinns i de flesta nordiska och övriga europeiska länder. I Island utgjorde kvinnor år 2001 drygt 60 procent av andelen universitetsstuderande och nästan dubbelt så många kvinnor som män i åldersgruppen 20-39 år har högskoleutbildning (Nordic Statistical Yearbook 2003, 137-138). Denna typ av könsskillnad överensstämmer nästan helt med mönstret i de östnordiska länderna. Jämfört med östra Norden har också

\footnotetext{
${ }^{40}$ Antalet islänningar och utländsk studieort finns redovisade i Nordic Statistical Yearbook 2003, 144-145.
} 
Island en större andel personer med enbart grundskoleutbildning, Norge, följt av Sverige, har flest med någon typ av vidareutbildning (aa 141). Statistiken från Färöarna visar ett mer ambivalent mönster, främst beroende på att antalet personer i olika åldersgrupper är begränsat. Under läsåret 2002/2003 var nästan 60 procent av de inskrivna vid Färöarnas universitet män, läsåret 2003/2004 var situationen den omvända och antalet kvinnliga studenter översteg antalet manliga med ungefär lika mycket (Árbók fyrí Føroyar 2004, tabell 18.25, 279). Eftersom det färöiska utbildningsutbudet är begränsat väljer majoriteten att studera utomlands. ${ }^{41}$ Samtidigt som andelen grönländska personer som väljer att genomgå en universitetsutbildning hemma eller utomlands ligger på en jämn nivå har andelen personer med examen från högskole- och universitetsutbildning i Grönland minskat mellan år 1997 och 2000 (Greenland 2001-2002, 171173). Liksom i övriga Norden domineras tekniska utbildningar inom tillverkning och byggverksamhet av manliga studenter medan kvinnor återfinns inom sjukvårdsutbildningar och inom samhällsvetenskapliga, humanistiska och omsorgsrelaterade utbildningar.

Som en introduktion till nästa avsnitt är det värt att understryka att det i och för sig finns många likheter mellan de västnordiska områdena och de östnordiska. Samtidigt framträder betydelsefulla skillnader mellan östoch västnorden men också mellan Färöarna, Grönland och Island. Eftersom både Färöarna och Grönland befinner sig under dansk överhöghet är antagandet att områdena lagstiftningsmässigt skulle likna Danmark mer än vad Island gör lika troligt som att alla tre, på grund av de specifika förhållandena som samhällena existerar under, i betydande avseenden välfärdspolitiskt skulle skilja sig från östra Norden. I flera grönländska och isländska analyser framträder betydande sociala och ekonomiska skillnader mellan olika befolkningsgrupper (Socialstatistik 2004:1, Socialstatistik 2004:2, Uden ehrversudvikling ingen velfcerdsutvikling 2003, Eydal, Ólafsson och Sigmarsdottir 2003b, Berntsson och Köhler 2001, Employment Outlook 2004). Det som gemensamt framhålls i studierna är

\footnotetext{
${ }^{41}$ Enligt uppgift från Stuðulsstovnurin och Almannastovan var 2004 ca 550 studenter inskrivna i vidareutbildning i Färöarna medan omkring 950 personer studerade i företrädesvis Danmark. I kontrast till Árbók fyrí Føroyar 2004, tabell 18.25, 27, meddelar man att kvinnor är i majoritet bland dessa. Diskrepansen har två förklaringar. Dels innefattar den vidarestuderande i en vidare bemärkelse, det vill säga inte enbart universitetsstuderande och dels omfattar den offentliga statistiken enbart de personer som uppbär någon form av utbildningsstöd från Färöarna.
} 
skillnader mellan grupper av bidragsberoende individer och dess huvudsakliga orsaker i låga inkomster eller arbetslöshet. Det är i sig inget uppseendeväckande, liknande socioekonomiska strukturer förekommer i flertalet västerländska välfärdsstater. Vad som framkommit från olika välfärdspolitiska studier som publicerats under de senaste 15 åren är att liknande utfall i till exempel klass- och könsmässiga ojämlikheter kan ha ganska olika drivkrafter i olika länder. Två av dessa är den välfärdspolitiska utformningen i respektive land, hur dess regelverk och ersättningsnivåer anknyter till olika grupper av individer samt arbetsmarknadens utseende och de regelverk som kringgärdar den (se t ex Huber och Stephens 2001, Daly och Rake 2003, Hantrais 2004). Fortsatta och mer ingående analyser av orsaker bakom fattigdom i Västnorden bör kunna visa på några av dess orsaker samt på effekter av olika statliga åtgärder och offentliga insatser.

Med hänvisning till att ett av huvuddragen i de övriga nordiska ländernas socialförsäkringssystem är att just utjämna och minska effekten av låg inkomst eller social utsatthet är det av intresse att se hur de västnordiska socialförsäkringssystemen är utformade. Det handlar till stor del om hur man välfärdspolitiskt ser på relationen mellan individ, arbete och välfärdsstat. Närmast följer en sammanställning av de socialpolitiska systemens regelverk. Jag tar därefter fasta på några av de eventuella effekter som utformningen av delar socialförsäkringssystemen kan ha på olika befolkningsgrupper. Det har här endast varit möjligt att studera och bearbeta det som i olika utsträckning synliggörs i de offentligt publicerade nationella materialen. 


\section{De västnordiska socialförsäkringssystemen}

Det tidsmässiga införandet av flertalet socialförsäkringssystem av både äldre och senare datum i Västnorden återspeglar, ibland med en viss fördröjning, händelseförloppet i de övriga nordiska länderna. De är utformade utifrån de specifika förutsättningarna för de västnordiska områdena, nämligen små och unga befolkningar, den nationalekonomiskt och arbetsmarknadsmässigt stora tyngdpunkten i fiskerinäringen med dess specifika förutsättningar, möjligen kombinerat med antaganden om en viss grad av familjeekonomisk självhushållning. De som arbetar inom olika nationella och utländska fiskeflottor lyder i alla tre länder under särskilda beskattningsregler och socialförsäkringssystem som är nog så betydelsefulla för enskilda individer med och utan försörjningsbörda. De specifika regelverk som kringgärdar delar av fiskerinäringen och dess anställa har tyvärr inte kunnat kommenteras närmare i detta arbete men förmodas utgöra en viktig delkomponent i förklaringen till de västnordiska ländernas välfärdspolitiska uppbyggnad och struktur.

Liksom i övriga Norden utgörs de inkomstrelaterade försäkringarna i västra Norden av en blandning av statligt finansierade universella, delvis inkomstbeprövade bidrag, vilka kompletteras med arbetstagar- och/eller arbetsgivarfinansierade delar. I följande översikt över de socialpolitiska program och ersättningsnivåer som finns i Färöarna, Grönland och Island presenteras en övergripande bild baserad på information gällande för perioden mellan 2002 och 2004 beroende på land. De angivna ersättningsnivåerna och tidsramarna utgörs av de andelar som är offentligt finansierade. Utöver dessa tillkommer alltså i vissa fall ytterligare ekonomiska tillägg som individer erhåller via framförallt kollektivt tecknade försäkringsavtal. Det har dock inte varit möjligt att, inom projektet ram, 
sammanställa och kommentera dessa. ${ }^{42}$ Den bild som återges är alltså inte fullständig eller uttömmande. De angivna nationella bidragsnivåerna är omvandlade till Euro för att öka överskådligheten. ${ }^{43}$

\section{Tabell 3}

\begin{tabular}{|c|c|c|c|}
\hline Socialförsäkringssystem & Färöarna & Grönland & Island \\
\hline Inkomstbeskattning & $\begin{array}{l}\text { Individuell/Sambeskat- } \\
\text { tning } 44\end{array}$ & Sambeskattning & $\begin{array}{l}\text { Individuell/Sambeskat- } \\
\text { tning }\end{array}$ \\
\hline Alderspension & $\begin{array}{l}\text { Generell folkpension, } \\
\text { ej individuell } \\
\text { Inkomstprövade tillägg } \\
\text { Obligatorisk yrkes- } \\
\text { relaterad tilläggspen- } \\
\text { sion }\end{array}$ & $\begin{array}{l}\text { Generell folkpension, } \\
\text { ej individuell } \\
\text { Delvis inkomst- och } \\
\text { behovsprövad }\end{array}$ & $\begin{array}{l}\text { Individuell, grundpen- } \\
\text { sion } 45 \\
\text { Inte behovsprövad } \\
\text { Obligatoriska } \\
\text { inkomstprövade } \\
\text { tilläggspensioner }\end{array}$ \\
\hline Förtidspension & $\begin{array}{l}\text { Inkomstrelaterad } \\
\text { Tregradigt invaliditets- } \\
\text { belopp, ej inkomst- } \\
\text { relaterat }\end{array}$ & $\begin{array}{l}\text { Delvis inkomst- och } \\
\text { behovsprövad }\end{array}$ & $\begin{array}{l}\text { Ersättning som för } \\
\text { ålderspension }\end{array}$ \\
\hline $\begin{array}{l}\text { Arbetslöshetsersätt- } \\
\text { ning }\end{array}$ & $\begin{array}{l}\text { Obligatorisk inbetal- } \\
\text { ning från arbetsgivare } \\
\text { och arbetstagare. } \\
\text { Inkomstrelaterad upp } \\
\text { till tak för minimilön för } \\
\text { icke facklärd arbetare } \\
\text { (ca } 68 \text { Euro/dag). } \\
\text { Max } 798 \text { dagar under } \\
\text { en femårsperiod. }\end{array}$ & $\begin{array}{l}\text { Arbetslöshetsför- } \\
\text { säkring existerar ej. } \\
\text { Viss ekonomisk hjälp, } \\
\text { enligt tariff, kan erbju- } \\
\text { das grupper av ar- } \\
\text { betslösa. }\end{array}$ & $\begin{array}{l}\text { Obligatorisk. avg från } \\
\text { arbetsgivare } \\
\text { Ej inkomstrelaterat } \\
\text { utan relaterad till } \\
\text { tidigare antal ar- } \\
\text { betstimmar, 10-39 } \\
\text { Euro/dag } \\
\text { Barntillägg } 4 \text { \%/barn } \\
\text { Max } 5 \text { år }\end{array}$ \\
\hline Sjukpenning & $\begin{array}{l}100 \% \text { upp till } 80 \% \text { av } \\
\text { lön för icke facklärd } \\
\text { arbetare. } \\
\text { Max } 40 \text { v/år } \\
\text { Ev ytterligare ersätt- } \\
\text { ning via avtal med ar- } \\
\text { betsgivare förekom- } \\
\text { mer. }\end{array}$ & $\begin{array}{l}90 \% \text { av minimilön } \\
\text { Max } 13 \text { v/år } 46\end{array}$ & $\begin{array}{l}\text { Efter } 14 \text { dagars karens } \\
\text { dagpenning max ca } 10 \\
\text { Euro. } \\
\text { Barntillägg } 2,45 \text { Euro. } \\
\text { Fackanslutna ev } \\
\text { tillägg. } \\
\text { Max } 52 \text { v/2 år. }\end{array}$ \\
\hline
\end{tabular}

(Fortsätter på nästa sida)

${ }^{42}$ En mer detaljerat utarbetad redogörelse av reglerna för de tre ländernas socialförsäkringssystem kan på förfrågan erhållas från författaren.

${ }^{43}$ Forex Internetservice för valutakurser har använts vid kalkylering och omvandling av ersättningsnivåer från nationella valutor till Euro.

${ }^{44}$ Sammanboende och gifta är i princip underordnade sambeskattning genom att mannen beskattas på hela sin och hustruns inkomst. Individuell beskattning är möjlig i de fall kvinnan har inkomst från arbete som ligger utanför mannens förvärv (Rigsombudsmanden på Færøerne.

Beretning 2003).

${ }^{45}$ Folkpensionen består av grundpension och alla folkpensionärer har rätt till grundpension. Dock har faktorer som t ex civilstatus och inkomst inflytande på det belopp som utbetalas (Velkommen til Island 2002).

${ }^{46}$ Sjukpenningen höjdes från och med januari 2005 från 55 procent till 90 procent av minimilön. I och med höjningen utgör grönländs sjukpenning idag en beskattningsbar inkomst. 


\begin{tabular}{|c|c|c|c|}
\hline Socialförsäkringssystem & Färöarna & Grönland & Island \\
\hline Sjukvård & Kostnadsfri & Kostnadsfri/Danmark & $\begin{array}{l}\text { Patientavgift för } \\
\text { läkarvård, } \\
\text { sjukhusvistelse kost- } \\
\text { nadsfri }\end{array}$ \\
\hline Socialbidrag & $\begin{array}{l}\text { Inkomst- och be- } \\
\text { hovsprövat. } \\
\text { Ekonomisk och mate- } \\
\text { riell ersättning. }\end{array}$ & $\begin{array}{l}\text { Inkomst- och be- } \\
\text { hovsprövat. } \\
\text { Ekonomisk och mate- } \\
\text { riell ersättning. }\end{array}$ & $\begin{array}{l}\text { Inkomst- och be- } \\
\text { hovsprövat. } \\
\text { Max } 1037 \text { Euro/mån. }\end{array}$ \\
\hline $\begin{array}{l}\text { Föräldrapenning/ } \\
\text { Föräldraledighet }\end{array}$ & $\begin{array}{l}\text { Totalt } 28 \text { veckor varav } \\
2 \text { tillfaller fadern i } \\
\text { samband med förlos- } \\
\text { sningen, } 16 \text { tillfaller } \\
\text { modern, } 10 \text { kan } \\
\text { fördelas mellan fö- } \\
\text { räldrar. } \\
\text { Ersättningsnivå } 100 \% \\
\text { av lön, max } \\
3267 \text { Euro/mån. } 47\end{array}$ & $\begin{array}{l}\text { Totalt } 25 \text { veckor varav } \\
17 \text { tillfaller modern, } 3 \\
\text { fadern och } 6 \text { kan } \\
\text { fördelas mellan fö- } \\
\text { räldrar. } \\
\text { Ersättningsnivå max } \\
\text { motsvarande lön för } \\
\text { icke facklärd arbetare. }\end{array}$ & $\begin{array}{l}\text { Totalt } 9 \text { mån där } 3 \\
\text { tillfaller modern, } 3 \\
\text { fadern och } 3 \text { kan } \\
\text { fördelas mellan fö- } \\
\text { räldrar. } \\
\text { Ersättningsnivå } 80 \% \\
\text { av lön upp till } 7700 \\
\text { Euro/mån. }\end{array}$ \\
\hline Vård av barn & $\begin{array}{l}10 \text { dagar per barn och } \\
\text { år, max } 2 \text { dagar per } \\
\text { sjuktillfälle. } \\
\text { Fackliga tariffavtal } \\
\text { finns. }\end{array}$ & -48 & $\begin{array}{l}10 \text { dagar per år, ej } \\
\text { relaterat till antal barn. }\end{array}$ \\
\hline Barnbidrag & $\begin{array}{l}\text { Finns ej. } \\
\text { Skattereduktion } \\
\text { tillämpas. } \\
\text { Underhållsstöd finns. }\end{array}$ & Behovsprövat & $\begin{array}{l}\text { Behovsprövat. Hänsyn } \\
\text { tas till föräldrars } \\
\text { civilstånd, inkomst, } \\
\text { antal barn och barnens } \\
\text { ålder. }\end{array}$ \\
\hline Barnomsorg ${ }^{49}$ & $\begin{array}{l}\text { Kommunalt ansvar. } \\
\text { Viss skolbarnsomsorg } \\
\text { finns. } \\
\text { Pris: } 1 / 3 \text { av den } \\
\text { faktiska kostnaden, } \\
\text { reduktion vid låg } \\
\text { inkomst. }\end{array}$ & $\begin{array}{l}\text { Kommunalt ansvar. } \\
\text { Pris; kalkyl baserad på } \\
\text { inkomst och driftskost- } \\
\text { nad för verksamhet }\end{array}$ & $\begin{array}{l}\text { Kommunalt ansvar, } \\
\text { hel- eller deltid. } \\
\text { Viss skolbarnsomsorg } \\
\text { finns. }\end{array}$ \\
\hline Bostadsbidrag & Finns ej & $\begin{array}{l}\text { Finns. Relaterad till } \\
\text { inkomst och famil- } \\
\text { jestorlek }\end{array}$ & $\begin{array}{l}\text { Finns. Relaterad till } \\
\text { inkomst och famil- } \\
\text { jestorlek }\end{array}$ \\
\hline
\end{tabular}

Källa: Sammanställningen i huvudsak baserad på uppgifter från Greenland in figures 2001-2002 och Greenland 2001-2002. Statistical Yearbook (2003) samt på uppgifter från Tom Greiffenberg, Birger Poppel samt Kirsten Olesen, Grönland. För Färöarnas del hänvisas till Allmanna- og Heilsumalastyrid mars 2002, Færøsk lovgivning omfattet af "Nordisk konvention om Social Sikring" pr. 1., Rigsombudsmanden på Færøerne. Beretning 2003 samt till uppgifter från Almannastovan. För Island hänvisas till Försäkringskassornas förbunds skrift Socialförsäkringen i Norden. En översikt (2004). Uppgifterna är kompletterade med information hämtad från Sigursteinsdóttir 2003, Eydal och Ólafsson (2003b och c) samt med kommentarer från Guðbjörg Linda Rafnsdóttir.

${ }^{47}$ Till och med 2003 var maximal ersättningssumma ca 4564 Euro (35 000 DKK). Från 2004 sänktes den maximala summan till 3260 Euro (25 000 DKK) (enligt uppgift från Petra Johnsdóttir Joensen, Almannastovan).

${ }^{48}$ Enskilda avtal kan finnas mellan grupper av arbetstagare och arbetsgivare.

${ }^{49}$ Täckningsgrader är relativt oklar för Färöarna och Grönland. För Islands del har den kommunala barnomsorgen kraftigt byggts ut under 1990-talet (Eydal och Ólafsson 2003c). 
Som framgår av tabell 3 är grunden för de västnordiska socialförsäkringarna, liksom för övriga Norden, i huvudsak ett universellt och offentligt finansierat och administrerat bidragssystem. Men i jämförelse med övriga Norden är ersättningsnivåerna inte avsedda att utgöra en ersättning för inkomstbortfall utan är, i de flera fall, lägre och behovsprövning utifrån framförallt inkomst och civilstatus är möjligen något vanligare. Visserligen är det oklart i vilken utsträckning olika bidrags- och försäkringssystem de facto ersätter uteblivna arbetsinkomster men givet en tidigare heltidsanställning och en inkomst som överstiger minimilönen för en outbildad arbetare förefaller bidragsnivåerna ändå att utgöra ett kraftigt ekonomiskt avbräck i människors försörjningsmöjligheter. För den som tjänar mer är glappet naturligtvis ännu större. ${ }^{50}$ Samtidigt är försäkringssystemen, och då särskilt arbetslöshets- och pensionssystemen, långt ifrån genomskådliga eftersom de till stor del är knutna till fackföreningsrörelser, arbetsgivarorganisationer och privata försäkringar och de ekonomiska ersättningsnivåerna för olika grupper är därför till exempel i Färöarna i vissa fall högre än vad som kan utläsas i tabellen. Inom det isländska systemet för tilläggspensioner hanteras 70 olika pensionskassor, organiserade efter yrkestillhörighet ${ }^{51}$. Det finns dock inga jämförbara uppgifter som gör det möjligt att bedöma effekterna av olika försäkringar på individnivå. I likhet med det danska pensionssystemet är grundbeloppet inkomstbeprövat och kan kombineras med en rad olika tilläggsförmåner så som bostadstillägg, pensionstillägg, barnpension och invaliditetsunderstöd (Socialförsäkringen i Norden. En översikt, 2004).

De västnordiska välfärdsystemen skiljer sig inbördes från varandra på betydande punkter. Färöarna och Grönland har färre individrelaterade bidragssystem än Island och brukar i högre grad beräkningar av hushållsinkomster som bevekelsegrunder för tilldelning av till exempel ålderseller förtidspension. $\AA$ andra sidan står den färöiska och grönländska arbetslöshetsersättningen och sjukpenningen i relation till tidigare inkomst medan de isländska snarare är relaterade till sysselsättningsgrad. Tillsammans med de inkomstbeprövade systemen med jämförelsevis låga tak för ersättningsnivåer bidrar den höga förvärvsfrekvensen bland kvinnor och män självklart till att hålla de sociala utgifterna nere. Andelen

\footnotetext{
${ }^{50}$ Man kan föreställa sig att de som uppbär en inkomst i nivå med den lägsta timlönen framförallt är unga och outbildade personer med ett yrkesliv framför sig. En facklärd eller på annat sätt mer erfaren förvärvsarbetande person bör ha en lön som överstiger den lägsta i lönetrappan.

${ }^{51}$ Se Socialförsäkringen i Norden (Försäkringskassornas förbund 2004).
} 
personer i pensionsålder är också lägre än i de östnordiska länderna och en icke försumbar del av dessa är fortstatt förvärvsarbetande. Som uppbärare av en inkomst är de inte berättigade till den inkomstprövade delen av ålderspensionen eller tilldelas ett reducerat pensionsbelopp. Utifrån informationen i tabellen kan man föreställa sig att den ekonomiska situationen för öppet arbetslösa personer ${ }^{52}$, ensamstående föräldrar, sjukskrivna, deltidsarbetande, förtidspensionerade och ålderspensionärer kan vara vansklig. Detta bekräftas delvis för Islands del av Ólafsson (2003a, 2003b, Eydal och Ólafsson 2003c) som beräknar att det reella värdet av pensioner, sjukpenning och socialbidrag minskat betydligt under senare delen av 1990-talet. Ólafsson menar att den politiska handlingslinjen som drivits i Island under senare år inte bara innebär en erodering av socialförsäkringssystemen utan att de universalistiska inslagen gradvis håller på att avvecklas och ersättas med ett meritokratiskt uppbyggd ersättningssystem.

Även i Färöarna och Grönland är delar av socialförsäkringssystemen under utbyggnad eller omvandling men det är kanske inte helt obefogat att i dagsläget anta att bidragsprövning mot bakgrund av civilstånd och familjeförhållanden idag inrymmer ett visst mått av dold fattigdom. En annan tänkbar möjlighet är att just familjeförhållanden och vänskapsband utgör en arena för utbyte av varor och tjänster som inte går att mäta via individers inkomst. Det är känt från ett flertal studier att stora mängder ekonomiska transfereringar och utbyten av tjänster sker mellan generationer och i handel med varor och tjänster utanför den formella arbetsmarknaden (Saraceno och Negri 1994, Mingione 1995, Saraceno 2000 och 2003, Gardberg Morner 2000 och 2003). Omfattning av, förutsättningar för och arbetssätt bland frivilligorganisationer, välgörenhetsorganisationer och andra typer av så kallade $\mathrm{NGOs}^{53}$ kan också spela en betydande roll. Särskilt i Grönland, där omkring 20 procent av befolkningen bor i glest bebyggda områden, vilar stora delar av individers och familjers försörjning på naturahushållning. Gruppen ensamstående manliga låginkomsttagare utgörs framförallt av fångstmän. I flertalet låginkomsttagande grönländska familjer har mannen lägre inkomst än kvinnan. Förklaringen till detta ligger i det faktum att det är hustrun som står för

\footnotetext{
${ }^{52}$ Med öppet arbetslösa avses de personer som inte har arbete men som vill och kan arbeta. Det innebär att personer i utbildning eller arbetsmarknadsåtgärder inte inkluderas i innebörden av begreppet.

${ }^{53} \mathrm{NGO}=$ Non Governmental Organisations.
} 
det betalda förvärvsarbetet och maken som sköter ytterligare en del av familjens försörjning via jakt. En förklaring till de förhållandevis låga ersättningsnivåerna ligger $\mathrm{i}$ att de är riktade till just dessa befolkningsgrupper. ${ }^{54}$ Det är oklart i vilken utsträckning liknande förhållanden återfinns i Färöarna och Island. Viktiga områden för vidare studier vore därför att närmare analysera inkomstrelationer mellan kvinnor och män i olika geografiska sammanhang och de sociala och ekonomiska effekterna av befintliga och alternativa socialförsäkringssystem på olika grupper i befolkningarna. Ytterligare andra intressanta forskningsområden berör olika aspekter på människors attityder till arbete och välfärd inom och mellan de tre länderna samt att kartlägga hur informella tjänster och ekonomiska överföringar ser ut i de västnordiska länderna.

Även om relationen mellan förvärvsarbete och barnafödande erkänns socialpolitiskt är den tidsmässiga omfattningen av föräldraförsäkringarna mindre än i Östnorden ${ }^{55}$ och har frammanat lite varierande föräldraförsäkringar, varav den isländska både tidsmässigt och ekonomiskt är den mest generösa i västra Norden. Samtliga är kopplade till inkomst från förvärvsarbete men i Grönland är ledigheten begränsad till 25 veckor och det högsta möjliga beloppet till att maximalt uppgå till minimilön för en outbildad arbetare. I Färöarna är föräldraledigheten begränsad till totalt 28 veckor men ersättningsnivån är hundra procent av tidigare inkomst. Islands föräldraförsäkring utgör åttio procent av tidigare inkomst och omfattar nio månader. I sina konstruktioner av föräldraförsäkringar erbjuder Färöarna och Grönland fäder att utnyttja begränsade delar av föräldraledigheten medan Island har den mest radikala föräldraförsäkringen i vilken båda föräldrar individuellt tillskrivs varsin tredjedel av de totalt nio månaderna. Inte i något annat nordiskt land finns politiska förväntningar på att pappor ska utnyttja en så stor andel av föräldraförsäkringen. Trots de betydande variationerna är föräldraförsäkringarna rent ekonomiskt mer generösa än flera av de övriga försäkringssystemen och har förbättrat den ekonomiska situationen för isländska småbarnsföräldrar betydligt. Synen på föräldraledigheten och dess förutsättningar är, liksom i övriga Norden, inte odelat positiv och även om fäder utnyttjar sin del, kvarstår till stor del en genusrelaterad konflikt mellan hem och arbete hos isländska par (Ei-

\footnotetext{
${ }^{54}$ Enligt uppgift från Birger Poppel och Kirsten Olesen, Grönland.

${ }^{55}$ För en genomgång av den östnordiska och isländska föräldraförsäkringarna och erfarenheter från dessa, se Valdimarsdóttir (2005).
} 
narsdóttir 2004b) och i relation till arbetsmarknaden. Ett flertal svenska studier visar på liknande erfarenheter (Bygren, Gähler och Nermo 2004, Nordenmark 2004, SOU 2005:66, SOU 2005:73).

Liksom i majoriteten europeiska länder är kopplingen mellan arbete och omsorgsansvar för barnomsorg och sjuka barn långt svagare i de västnordiska ländernas socialförsäkringssystem än vad föräldraförsäkringen är. Betald frånvaro från arbetet när barnen är sjuka erbjuds endast i mycket begränsad utsträckning i Färöarna och Island och inte alls i Grönland. Till skillnad från östra Norden finns inget generellt stöd till barnfamiljer i form av barnbidrag. Istället tillämpas behovsprövade bidrag i Grönland och Island. I Färöarna appliceras ett indirekt stöd via kommunalt reglerade skattelättnader vid försörjningsbörda för minderåriga. För Islands del utgör utbetalningar av de behovsprövade barnbidragen och andra familjerelaterade bidrag, trots den högre nativiteten, en lägre andel av BNP än i de övriga nordiska länderna (Ólafsson 2003a). En utbyggnad av barnomsorgen pågår $\mathrm{i}$ alla tre länder och även här läggs stor vikt vid det offentligas ansvar för tillgång, om än inte alltid för tillhandahållandet av daghemsplatser. Själva tjänsten utförs delvis av icke-kommunala organisationer. I ett antal studier av olika europeiska länders hantering av barnomsorg i relation till förvärvsarbete har det framkommit att barnomsorg arrangerats med framförallt pedagogiska motiv och inte alltid i relation till föräldrars arbetstider (Sundström 2003, Hantrais 2004). Kopplingen mellan andelen kvinnor på arbetsmarknaden, barnomsorg och arbetstider har därför varit svag. Enligt Eydal (2000) och Eydal och Ólafsson (2003b) har detta präglat den isländska barnomsorgen fram till början av 1990-talet. Även om barnomsorgen är under stark utbyggnad finns ingen rätt till garanterad plats till barnomsorg.

Eftersom flera av försäkringssystemen är inkomstrelaterade innebär sambeskattning av gifta och sammanboende par i Grönland, och delvis i Färöarna, möjligen en minskad betydelse av två inkomster och kanske också av barnomsorgsplatser för vissa inkomstgrupper eftersom en förälder då anas tillbringa mer tid hemma. För Färöarnas del gäller dock sambeskattning endast för gifta och sammanboende par där båda arbetar i eget familjeföretag. I familjer där kvinnor har anställning hos annan arbetsgivare är inkomstbeskattningen individuell. I Island är sambeskattning eller individuell beskattning valfri. Det är tänkbart att sambeskattning medför att brytpunkten för ålderspension, förtidspension, socialbi- 
drag och barnbidrag placeras så att effekten av två förvärvsinkomster reducerar möjligheterna att få del av de inkomstbaserade bidragsbeloppen. Den höga kvinnliga förvärvsfrekvensen till trots, tvåförsörjarfamiljen borde inom vissa inkomstkategorier därmed utgöra en sämre familjeekonomisk strategi än familjer med endast en inkomst. Man kan också förmoda att de främsta förmånstagarna av barnbidrag och den generella ålderspensionen i Färöarna och Grönland är personer som är ensamstående respektive ensamstående föräldrar, för Islands del framförallt den senare gruppen. Skatte- och omfördelningssystemen innehåller sannolikt också inbyggda fattigdomsfällor i marginalskatteeffekter som kan medföra att en ökad familjeinkomst för en låginkomsttagande familj de facto kan innebära en minskning av den disponibla inkomsten eftersom familjen går miste om vissa bidrag.

De välfärdspolitiska handlingslinjer som kan uttolkas pekar idag därmed i två riktningar. Inom vissa socialförsäkringsområden följer handlingslinjerna en familjeorienterad, restriktiv och behovsprövande logik, inom andra områden framträder en generösare linje knuten till principer om individuella sociala rättigheter för yrkesverksamma personer. Vilka är då grupperna i riskzonen för marginalisering och som i huvudsak är hänvisade till de behovsprövade bidragen?

Innebörden av marginaliseringstendenser baserade på standardmått för levnadsnivåer, minimiinkomster och fattigdomsmått har inte givits något större utrymme i de offentliga nationella färöiska, grönländska och isländska statistiska materialen. För att ge en mycket översiktlig bild av vilka grupper som är mottagare av olika socialförsäkringssystem har beräkningar gjorts utifrån tillgängliga data kring socialbidragstagande, förtidspensioner, ålderspensioner och arbetslöshetsersättning. Syftet är inte att ge detaljerade uppgifter utan att se om det går att finna eventuella stratifierande eller marginaliserande tendenser inbyggda i de västnordiska samhällenas välfärdssystem.

\section{Marginaliseringstendenser $\mathrm{i}$ Västnorden}

Mot bakgrund av en relativt snabb förändring av levnadsförhållanden och förutsättningar för försörjning bland befolkningar i de arktiska områdena understryker Thomas Andersen (1999) behovet av internationellt jämförbart statistiskt material som tar hänsyn till såväl specifika ekonomiska 
förhållanden som till kulturella särdrag. Den första grönländska levnadsnivåunderökningen genomfördes 1994 och bar stark prägel av den skandinaviska traditionen att samla objektiva socioekonomiska data på individnivå för att därefter mäta fördelningen av resurser mellan olika samhällsgrupper. Bland de problem som uppstod nämner Andersen framförallt bekymmer med att mäta socioekonomiska levnadsförhållanden med indikatorer som förvärvsfrekvens, inkomst, boendestandard eller utbildningsnivå. Levnadsförutsättningarna för delar av Grönlands befolkning styrs av andra kriterier som är närmare knutna till självhushållning. Ekonomisk fattigdom behöver alltså, enligt Andersen, inte nödvändigtvis indikera social marginalisering. Andersen ifrågasätter därför den inneboende förståelsen av begreppet välfärd och de objektiva indikatorer som används för att mäta levnadsnivå. Vidare redogör Andersen för ett pågående internationellt projekt för levnadsnivåunderökningar i den arktiska regionen inom vilket ett större inslag av befolkningars egna förståelser av välfärd bör ingå samt utarbetande av mått på individuella resurser som sociala relationer, familjemönster, tillgång till naturresurser samt uppfattningar kring politisk tillit och inflytande. Dessa synpunkter är i olika utsträckning relevanta även för Färöarna och Island där förväntningar på individers förmåga till självhjälp och ekonomisk självförsörjning ser något annorlunda ut jämfört med östra Norden. Diskussioner och normativa uppfattningar kring välfärd framträder, på ett tydligare sätt än i östra Norden, som en mix av modern nyliberalism och ett slags egalitärt strävande nybyggaranda. Välfärdspolitiskt har denna mix givits familistiska ${ }^{56}$ inslag när det gäller synen på ansvarsfördelning inom äktenskapet och mellan familjemedlemmar samt i förståelsen av statens roll visavi individen. Som vi ska se nedan framträder dock drag inom de västnordiska välfärdsstaterna som i sina segregeringsmekanismer i mycket liknar övriga Norden och för övrigt flertalet västeuropeiska länder.

Storleken och omfattningen av de västnordiska socialförsäkringssystemen återspeglas delvis i distributionen av inkomster och andra aspekter på välfärd. Även om all socialpolitik kan sägas ha som yttersta mål att bidra till omfördelning av olika samhälleliga resurser framstår

\footnotetext{
${ }^{56}$ En välfärdsregim inom vilken en stor del av ansvaret för individers välfärd läggs på familjen och i vissa fall även på anhöriga i en vidare bemärkelse. Omsorgsansvar faller därför i första hand på mödrar och döttrar, det ekonomiska ansvaret på fäder och söner. Först när familjen är utan möjlighet att försörja sina medlemmar eller ge omsorg tar det offentliga ansvaret ta vid (Saraceno 1994).
} 
avsikten bakom delar av de västnordiska socialförsäkringarna som att i första hand erbjuda individer relativt begränsade ekonomiska stöd. Bland de befolkningsgrupper som löper störst risk att hamna i ekonomisk fattigdom brukar ensamstående föräldrar, barn och äldre framträda. De huvudsakliga orsakerna till att just dessa grupper lider brist på ekonomiska resurser är att familjer under en tidsperiod i livet har en utökad försörjningsbörda eller att de ännu inte, alternativt inte längre, kan försörja sig via arbete. Detta är mönstret även i den nordiska välfärdsmodellen men även om dessa grupper lever med mycket begränsade resurser i Danmark, Finland, Norge och Sverige är barnfattigdom, graden av fattigdom bland ensamstående föräldrar, vilka företrädesvis är kvinnor, eller andelen fattigpensionärer inte särskilt utmärkande för de östnordiska länderna jämfört med övriga länder i västvärlden. Förklaringarna till att antalet fattiga bland dessa grupper är lågt brukar anges ligga i att subventionerad barnomsorg och skolbarnomsorg är förhållandevis väl utbyggd och i att kvinnor, och då särskilt ensamförsörjande kvinnor med barn, har en hög förvärvsfrekvens. Boendestandard och levnadsstandard är förhållandevis hög även bland grupper med små ekonomiska resurser. Dessutom erbjuds barn i vissa av de nordiska länderna dagligen lagad mat inom både barnomsorg och skola. Förekomsten av undernäring, barndödlighet och fattigdomsrelaterade sjukdomar är låg. De statliga ålderspensionerna i de östnordiska länderna är högre än i flera västeuropeiska länder och kan, via kommunerna, kompletteras med till exempel bostadsbidrag och subventionerad omsorgsservice.

Även om materialen som består av ländernas nationella statistik över sociala utgifter och uppgifterna inte är vare sig kompletta eller helt jämförbara över nationsgränserna framträder ändå vissa mönster som i mångt och mycket överensstämmer med de man återfinner i östra Norden och övriga Västeuropa. ${ }^{57}$ Uppgifterna är i huvudsak fördelade i enlighet med hur medel utbetalats till hushåll respektive till män och kvinnor och det är därför framförallt ur en hushålls- och könsdimension som resultaten kan diskuteras. Andra aspekter på segregeringsmönster som ålder, utbildningsnivå, bostadsort, etnicitet och liknande kan alltså inte jämföras här. Det går heller inte att från den tillgängliga statistiken utläsa i vilken mån

\footnotetext{
${ }^{57}$ Statistiken nedan är hämtad från Árbók fyri Farøya 2004, Sigursteiensdóttir 2003 och Grønlands statistik 2004; Socialstatistik 2004:1 och 2004:2.
} 
hälsoproblem i vidare bemärkelse är förknippade med någon av de ovan nämnda aspekterna.

Om vi följer ordningsföljden i tabell 3 och först ser till antalet personer med enbart statlig ålderspension i de olika länderna utgör kvinnor en klar majoritet. Det är sannolikt en effekt av att det finns fler äldre kvinnor än män och av att den kvinnliga förvärvsfrekvensen tog ordentlig fart först på 1970-talet. Eftersom kvinnors in- och utträde från arbetsmarknader ofta avgörs av deras möjligheter att kombinera omsorgsansvar med lönearbete har många kvinnor troligtvis inte haft möjlighet att etablera sig inom olika privata eller kollektiva pensionsförsäkringssystem. Inom gruppen förtidspensionerade dominerar kvinnor i antal i Färöarna och Island men bland de förtidspensionerade återfinns flest kvinnor inom gruppen som enbart får den generella grundersättningen medan det bland män finns fler som är berättigade till de supplementära ersättningarna. I Grönland är andelen män med förtidspension något större än andelen kvinnor men de lokala variationerna är stora. Även här är män överlag berättigade till högre ersättningsnivåer än kvinnor (Socialstatistik 2004:1 och 2004:2).

När det gäller arbetslöshetsersättning tyder statistiken på att män som grupp oftare är berättigade ekonomiska bidrag från arbetslöshetsförsäkringar. Kvinnor utgör istället majoriteten bland personer som erhåller behovsprövade ekonomiska bidrag så som socialbidrag och olika typer av bidrag som kan erhållas i kombination med låg inkomst. Till dessa hör olika typer av socialbidrag, barnpension, barnbidrag, bostadsbidrag och liknande. I en sammanställning från Grönlands statistik pekar man på att det framförallt är personer i åldersguppen 30-39 som berättigas behovsprövade bidrag. Män tilldelas visserligen en större andel av den totala summan av sociala utgifter men kvinnor är i antal överrepresenterade inom de flesta bidragssystemen (Socialstatistik 2004:1 och 2004:2). I Island befann sig i slutet på 1990-talet knappt sju procent av befolkningen under fattigdomsgränsen, det vill säga förfogade över mindre än 50 procent av medianinkomsten för alla löntagare (Eydal, Ólafsson och Sigmarsdottir 2003c, 23). Inom denna grupp utgjorde kvinnor en majoritet, särskilt gruppen ensamstående med barn. Andra grupper som enligt detta mått är att betrakta som fattiga är studenter, arbetslösa och personer som inte står till arbetsmarknadens förfogande. I Island utgjorde kvinnor under 2001 och 2002 drygt 62 procent av det totala antalet socialbidragstagare 
och emottog närmare 70 procent av den totala summan som utbetalades under åren. ${ }^{58}$ I Island är andelen långtidsarbetslösa kvinnor också högre än andelen män. ${ }^{59}$ De främsta bidragsposterna för kvinnor kan framförallt relateras till gruppen ensamförsörjande föräldrar. När det gäller isländska män är den största bidragstagande gruppen ensamstående män utan barn (Employment Outlook 2004, 116-117). Tyvärr är det inte möjligt att utifrån grönländsk eller färöisk statistik säga något om eventuella samband mellan kön, försörjningsansvar och bidragsberoende. Möjligen finns vissa förbindelser mellan sjukförsäkring och socialbidrag. Eftersom sjukförsäkringen är tidsbegränsad är det troligt att långtidssjuka personer överförs till socialbidragstagande efter det att sjukförsäkringstiden har löpt ut.

${ }^{58}$ Egen beräkning gjord utifrån Sigursteinsdóttir 2003, 105.

${ }^{59}$ Enligt OECDs beräkning av långtidsarbetslösa utgjorde andelen kvinnor som var arbetslösa mer än 6 månader 32,6 procent av den kvinnliga arbetskraften under 2002. Motsvarande siffra för män var 19,4 procent. Bland de som var arbetslösa mer än ett år var det 13,3 procent av den kvinnliga arbetskraften och 9,5 procent av den manliga (Employment Outlook 2004). 


\section{Den västnordiska välfärdsstatens politiska och ekonomiska inriktning}

Det har inom ramen för detta arbete inte varit möjligt att studera vilka välfärdspolitiska diskussioner som är aktuella på nationella eller lokala nivåer. Istället har fokus lagts på att diskutera de färöiska, grönländska och isländska välfärdspolitiska inställningarna mer generellt. Vid en närmare studie av de välfärdspolitiska riktlinjerna i Västnorden står det klart att områdena i stora delar skiljer sig från länderna i östra Norden. Historiskt har de dominerande politiska partierna i Färöarna och Island vädjat till värderingar kring nationell och individuell självständighet och varit uttalade anhängare av liberala marknadsteorier (Jónsson 1995, Mørkøre 1997a). Från statligt politiskt håll har man i hög grad förlitat sig på ländernas egna exportfördelar när det gäller råvaruindustri och av ett, i ett nordiskt perspektiv, större avståndstagande från progressiva beskattningsmodeller och en socialpolitiskt interventionistisk stat. Fackförenings- och partipolitiska arbetarrörelser har haft relativt litet inflytande (Jónsson 1995, Lyck 1997b, Mørkøre 1997b, Motzfeldt 1997, Ólafsson 1999 och 2004, Jonsson, G. 2001). Det grönländska politiska systemet har dock, sedan hemstyrets införande 1979, i större utsträckning präglats av det socialistiska blocket. För att sammanfatta de argument och slutsatser som framförs i de skilda analyserna så beskrivs de västnordiska områdena som inbördes olika och enbart delvis lika de östnordiska. Framförallt i Färöarna och Island har behovet av marknadsrelaterade och meritokratiskt inspirerade korporativistiska lösningar understrukits (Jónsson 1995) vilka också på senare år i allt högre utsträckning verkar ha kommit att dominera delar av socialförsäkringssystemen. Samtidigt som ägar- och inkomstbeskattningen är lägre har dessa system kanske färre inslag av omfördelande ambitioner än i de övriga nordiska länderna. 
Ett vanligt argument för att hålla ersättningsnivåerna på en låg nivå är att de då inte erbjuder individer ett ekonomiskt alternativ till förvärvsarbete samtidigt som de skänker en ekonomisk lättnad till verkligt behövande. Argumentationen brukar ofta kombineras med marknadsvänliga värderingar och en syn på individualism och självständighet där självförsörjning, personliga kontakter och familjen utgör individens främsta källa till ekonomisk och social trygghet och välfärd. Parallellt med uppfattningen att västnordiska invånare präglas av en mycket stark arbetsetik framhålls dessa argument som viktiga även i den välfärdspolitiska retoriken och lagstiftningen (Mørkøre 1997b, Hannibalsson 2004). Politiskt har därmed familjen som en enhet tillskrivits en större social och ekonomisk betydelse för individens välfärd än vad som i varje fall sedan 1970-talet varit normen i flera av de övriga nordiska länderna och män har mer uttalat betraktats som huvudförsörjare och kvinnor som omsorgsansvariga (Broddadóttir et al 1997, Oláfsson 1999, Eydal 2000, Jonsson, G 2001, Jákupsstovu kommande). I syfte att stödja individens och familjens självständighet har större vikt därför lagts på utformning av ekonomiska transfereringssystem som möjliggör skattesubventioner till gifta par och familjer med minderåriga barn och hemarbetande kvinnor snarare än offentlig service och kvinnors förvärvsarbete.

\section{Ekonomiska och politiska makteliter}

I ett flertal studier framhävs betydelsen av sammansättningen av de politiska och ekonomiska makteliterna i de västnordiska områdena. Dels utgör de en komponent till förståelsen för och utformningen av välfärdspolitiska åtgärder i vid bemärkelse, dels bidrar de till att belysa de socioekonomiska strukturerna i de olika länderna (Jónsson 1995, Apostle et al 2002). Förekomsten av olika typer av makteliter är naturligtvis inte specifik för de västnordiska områdena men möjligen är de mer synliga och kanske politiskt och ekonomiskt starkare i små befolkningar än i länder med större befolkningar och flera parallella grupper som aspirerar på politiskt och ekonomiskt inflytande. Sammantaget utgör såväl sammansättningen av eliter, den välfärdspolitiska utformningen och de sociala och ekonomiska strukturerna viktiga delar i skilda författares förklaringar till förekomsten av strukturellt betingade ekonomiska, politiska och sociala skillnader mellan olika befolkningsgrupper (se till exempel 
Jónsson 1995 och 1999b, Sipilä 1997, Petersen och Poppel 1999, Ólafsson 1999, Apostle 2002, Winther 2003a). Jákupsstovu och Kjersem (2004) hävdar att rekryteringen av kommunalpolitiker i Färöarna inte medfört någon större politisk debatt, bortsett från att en ökad representation av kvinnor från politiskt håll har framhållits som önskvärt. Det finns ingen egentlig studie eller sammanställning av hur de faktiska makteliterna i de västnordiska områdena är sammansatta eller hur tilliten till dessa ser ut men i sin analys av politiska och ekonomiska processer i Västnorden hävdar Jónsson (1995, 101-104) att den nära förbindelsen mellan familjeband, vänskapsrelationer, privata ekonomiska egenintressen och politiska ambitioner har medfört att framförallt ekonomiska styrkepositioner ofta varit av avgörande betydelse för beslutsfattande på såväl lokal som central politisk nivå och därmed också för den politiska och ekonomiska stabiliteten i de västnordiska områdena. I kombination med en liten inhemsk marknad, svaga och inbördes konkurrerande fackföreningsrörelser och en underdimensionerad administrativ sektor utgör förekomster av lokala och centrala makteliter, enligt Jónsson, betydande delförklaringar till den svaga utvecklingen av politiskt initierade program för en mer långsiktig ekonomisk utveckling och mer omfattande välfärdspolitiska åtgärder. Jónsson hävdar också att statliga initiativ på framförallt Färöarna och Island har haft starka inslag av privata egenintressen eftersom de politiska förutsättningar som står för handen via små men inflytelserika företag bäddar för starka familje- och vänskapsband inom såväl den ekonomiska som den politiska sfären. Eftersom ekonomin på framförallt Island och Färöarna domineras av familjeföretag eller kooperativt ägda företag finns endast förhållandevis små ekonomiska resurser och tekniska kunskaper för långsiktig planering. Istället utgör de en grogrund för starka inslag av korruption och nepotism i den ekonomiska, politiska och sociala livet (Jónsson 1995, kap 5).

Även Grönland domineras av en social, ekonomisk och politisk elit men situationen är något annorlunda eftersom företagsstrukturen snarast utgjorts av statligt ägda och administrerade bolag och privat ägande inte varit lika dominerade. Det har medfört att mer långsiktig planering och mer investeringskrävande insatser har varit lättare att genomföra. På basis av en omfattande intervjuundersökning med grönländska makthavare analyserar och diskuterar Wolfang Kahlig det grönländska ledarskapets sammansättning, förutsättningar och framtid i Leder i Grønland - en 
kvalitativ holdningsundersøgelse (1999). Mot bakgrund av de utbildningsmässiga, ekonomiska och politiska övertag som danskar och grönlänningar utbildade i Danmark har över övriga grönlänningar framträder en tydlig dansk/grönländsk elit. Kahlig visar exempel på den dagliga närvaron av konflikter mellan danskar och grönländare och diskuterar dess orsaker och möjliga positiva effekter i vad han kallar "bikulturell synergi”. Med detta avses de potentiella fördelar som utvecklandet av det grönländska hemstyret kan dra av att inom konkreta områden, som till exempel det arbetsmarknadspolitiska, kombinera grönländska kulturella föreställningar och idéer kring organisation med valda delar av det danska institutionella och kulturella arvet. Även om en stor del av de grönländska företagen är gemensamt ägda är det demokratiska problemet ändå att en ny politisk och ekonomisk elit har vuxit fram med hemstyret vilken tenderar att ockupera såväl politiska som ekonomiska positioner inom offentliga institutioner och offentligt ägda företag (Jónsson 1995, Kahlig 1999, Winther et al 2003a).

Den socioekonomiska sammansättningen av makteliter medför att frågan om välfärdspolitiska handlingslinjer inte är helt okomplicerad, inte minst eftersom delar av den nordiska modellen, som tidigare nämnts, betraktas med viss misstänksamhet i de västnordiska länderna. Till den diskussionen skulle ett flertal aspekter kunna läggas till hur representationen av könspolitiska och klassmässiga frågor har representerats och hanterats i relation till såväl politiska och ekonomiska makteliter och hur välfärdspolitiska frågor har behandlats under olika epoker under efterkrigstiden. Arbetarrörelser i Färöarna och Grönland är fördelade över ett större antal mindre fackföreningsorganisationer som på grund av omfattande externa och interna migrationsrörelser har ett kraftigt in- och utflöde av medlemmar och är både internt och externt fragmenterade. Det senare tar sig uttryck i att fackföreningsrörelserna till betydande del är konkurrenter om arbetstillfällen och därför riskerar att hamna i intressekonflikter med varandra. Därmed hotar samarbetssvårigheter vilket i sin tur underminerar arbetstagarorganisationernas möjligheter att erövra en gemensam styrkeposition vis à vi arbetsgivare och politisk ledning. För Islands del understryker Ólafsson (1999, 2004) dock betydelsen av en jämförelsevis svag och splittrad politisk vänster i efterkrigstidens Island och som endast sällan och under kortare perioder har haft inflytande över den annars högerpolitiskt dominerade politiska dagordningen. Däremot 
har den vänsterorienterade fackföreningsrörelsen till och från haft en styrkeposition och varit den främsta motorn i införandet och utvidgningen av sociala rättigheter.

De ekonomiska, politiska och administrativa problemen i framförallt Grönland, men av betydelse även i Färöarna och Island, understryks av ett flertal författare. En faktor som uppmärksammas särskilt (Pedersen och Poppel et al 1999, Winther et al 2003a och 2003b) är ursprungsbefolkningars värderingar, förhållningssätt och strategier till stöd för sina samhällens långsiktiga hållbarhet och bärkraft i en globaliserad värld med förändrade politiska förhållanden, levnads- och produktionsvillkor och marknader. Såväl kulturella, fysiska och socioekonomiska förutsättningar står delvis i konflikt med och betraktas av vissa grupper som oförenliga med ett västeuropeiskt autonomifokuserat och individualistiskt rätts- och jämlikhetsbegrepp rörande principer kring fördelning av individers ansvar, skyldigheter och individuella och samhälleliga resurser. I en kortfattad diskussion kring den sociala dimensionen och förståelsen av begreppet jämlikhet i relation till olika innebörder av koncept som "hållbar utveckling” diskuterar bland andra Torben Agersnap (1999) Grönlands svårigheter att både dra fördel av och övervinna sitt danska arv. Agersnap tar upp utbildningspolitik, tvåspråkighet och frågan om social stratifiering. Enligt Agersnap har det kraftigt ökande andelen lönearbetande i Grönland medfört socioekonomiska förskjutningar i den grönländska befolkningen så att tidigare statushierarkier inom jakt- och fiske har förlorat i rättigheter och inflytande till förmån för nya grupper inom näringsgrenar som prospektering av olja och mineraler och privata och offentliga serviceyrken. Mycket talar för att en liknande situation återfinns i Färöarna (se Apostle 2002). I Island, med sin mer diversifierade arbetsmarknad, har förändringsprocessen förmodligen kommit längre. Det framgår med all tydlighet att såväl klass som etnicitet är av mycket stor objektiv betydelse för välfärd i det grönländska samhället. I den grönländska maktutredningen (Winther et al 2003a) efterlyses studier av och handlingsplaner som syftar till att öka det politiska systemets legitimitet och reducera den "politiska fattigdomen"60 (Andersen och Tonsgaard 2003). De politiskt fattiga utgörs av de grupper som på grund av bostadsort, utbildningsnivå, inkomst och etnicitet tenderar att uteslutas från den politiska

\footnotetext{
${ }^{60}$ Författarna lånar begreppet från Martinussen, Willy (1973) Fjerndemokratiet. Oslo: Norsk Gyldendal.
} 
debatten och den politiska arenan och som därmed har svårt artikulera krav till de politiska systemen och beslutsfattande organen. Bland annat understryks behov av vidare studier kring genomdrivandet av en västerländsk parlamentarisk välfärdsstatsmodell och dess relation till en framväxande klasskonflikt med socioekonomiska och strukturella förtecken. Enligt Andersen och Tonsgaard riskerar denna konflikt att förstärkas med det av OECD (1999) föreslagna införandet av större marknadsekonomiska inslag, via privatisering av tidigare offentligt ägda företag, och marknadsmässig prissättning på varor och tjänster samt med det växande behovet av utbildad arbetskraft.

Även om de politiskt administrativa sektorerna i Västnorden är uppbyggda på delvis olika premisser beskrivs de av Jónsson som förbluffande små och delvis i avsaknad av både kompetens och resurser för att utveckla och förverkliga långsiktiga strategier samt för att utgöra ett ledande entreprenörskap för nya produkter (1995, 101-104). Särskilt det grönländska samhället är också präglat av en dansk teknokrati som möter svårigheter när det gäller att förstå sig på och anpassa sig till de specifika grönländska förhållandena. Enligt Jónsson (1999a) är detta avgörande förklaringar till rigida klassrelationer och stagnerade socioekonomiska strukturer i Västnorden. Tillsammans med effekten av en relativt liten befolkning och en liten intern marknad innebär det bland annat också att framväxten av en politiskt oberoende och effektiv administration med tydliga hierarkier och ett neutralt bemötande av medborgare förefaller svår att uppnå och upprätthålla. Problemet belyses också av flera av författarna i den grönländska maktutredningen. Som en följd av kvarlevande koloniala maktstrukturer inom det grönländska myndighetssystemet följer språkkonflikter, misstänksamhet och låg tilltro till dess förmåga att göra välavvägda bedömningar (Petersen 2003, Langgård 2003).

\section{Kön och politik}

I ett flertal färöiska, grönländska och isländska analyser framhålls kulturella och värderingsmässiga förklaringar till skillnader i välfärdspolitiska inriktningar mellan västra och östra Norden. I korthet sägs de västnordiska samhällena, och då framförallt Färöarna och Island, präglas av en stark individualism och nybyggaranda som tar sig uttryck i en kombination av framhävandet av nationellt oberoende och i den uttalade tilltron till 
individens förmåga att självständigt bemöta och lösa svårigheter. Därmed hänvisas till exempel det juridiska och moraliska ansvaret för individens välfärd och omsorgsbehov, i större utsträckning än i övriga Norden, till individen och familjen. För Färöarnas och Grönlands del är det sammanvävt med arbetet med att finna en väg ut ur en postkolonial ställning och en ekonomiskt och politiskt impregnerad beroendeställning, där det danska inflytandet inom en mängd olika områden betraktas som både en förutsättning, en tillgång och ett hinder. I det grönländska samhället har kön och jämställdhet sedan införandet av hemstyre och fram till 2000talets början inneburit ett komplicerat politiskt tema som stött på många hinder i de mer formella politiska och administrativa sfärerna.

Ett flertal författare hävdar att olika typer av värderingsmässiga inslag i de västnordiska länderna tillsammans har kommit att utgöra ett slags "kulturella hinder" (Eydal 2000, 121) för samordning av feministiska krav och för koordination av mer allmänpolitiska krav i syfte att stödja kvinnofrågor men också ett medel för politiska partier i sin strävan att undvika att utnyttja skatteintäkter till omfördelning och utbyggnad av den sociala servicen (Broddadóttir et al 1997, Mørkøre 1997a, Oláfsson 1999, Jonsson, G 2001). Enligt Jákupsstovu uppvisar Färöarnas välfärdspolitiska utformning, om än inte i sin historiska motivering, i denna bemärkelse fortfarande vissa likheter med de familjeorienterade, korporativistiska (familistiska) välfärdsregimerna i centrala och södra Västeuropa i vilka en manlig familjeförsörjarmodell på olika sätt uppmuntras via skatte- och transfereringssystem och där ansvaret för omsorgsarbete huvudsakligen hänvisas till familjen (Jákupsstovu 2003). Den historiska motiveringen skulle kanske kunna härledas till en mer traditionell komplementär jämställdhet baserad på skillnad och isärhållande av arbetsuppgifter utan att dessa i sig innefattar hierarkiska betydelser. På grund av den institutionella utbyggnaden i Grönland, det relativt sett högre antalet kvinnor med eftergymnasial utbildning och det faktum att det i många fall är kvinnor som ekonomiskt sett är huvudförsörjare i familjer bör ett utbyggt socialförsäkringssystem baserat på lönearbete därmed gynna kvinnor framför män.

De västnordiska nationella och lokala politiska arenorna domineras av män. Även i detta sammanhang framhåller Eydal (2000) och Einarsdóttir (2003) värderingsmässiga grunder som förklaringar till den låga, eller i Islands fall sjunkande, nivån för kvinnors politiska deltagande. I redogö- 
relser för den politiska kvinnorepresentationen i Färöarna, Grönland och Island framkommer att motståndet mot kvinnor inom politiken och mot kvinnopolitiska krav på till exempel jämställdhetslagstiftning har varit relativt omfattande (Jákupsstovu 1996, Jungerstam-Mulders 1999, Einarsdóttir 2003). Även om en hel del kvinnor deltar i politiskt arbete och kandiderar till politiska förtroendeposter är kvinnor som grupp underrepresenterade i hela Västnorden. I likhet med många andra länder återfinns de istället oftare på kommunala förtroendeposter än på nationell nivå, även om variationen mellan kommuner är stor. År 1976 utökades tidigare isländsk jämställdhetslagstiftning kring lönesättning till en mer omfattande jämställdhetslagstiftning (Einarsdóttir et al 2002) ${ }^{61}$. I Färöarna introducerades en jämställdhetslag i mitten av 1990-talet och kommittéer inrättades. Sedan 1998 har Grönland ett Jämställdhetsråd (Ligestillingsrådet) och år 2003 fick Grönland sin första jämställdhetslag. I Färöarna har kvinnor varit kraftigt underrepresenterade i politiska institutioner långt in på 1990-talet (Jákupsstovu 1996). Under senare tid har ett politiskt initierat arbete påbörjats för att utforma en nämnd som mer specifikt ska arbeta med att öka kvinnors deltagande i de folkvalda organen. Målsättningen är att närma sig den mer jämställda representationen i östra Norden. I Island drevs jämställdhetsfrågor aktivt av feministiska rörelser och av ett kvinnoparti från 1970-talet och fram till 1995 då Kvinnopartiet upplöstes och dess medlemmar övergick till andra etablerade partier (Einarsdóttir 2003). Därefter har andelen kvinnor i riksdag och regering minskat och antifeministiska argument som avfärdar betydelsen av kön som segregeringsmekanism har ökat i antal och styrka (Einarsdóttir 2003). ${ }^{62}$ Inom forsknings- och utredningsarbete förefaller dock delar av den isländska kvinno- och jämställdhetsrörelsen fortfarande vara aktiv (Einarsdóttir 2004a).

Även om kvinnor är underrepresenterade i den grönländska politiken visar en grönländsk attitydundersökning att kvinnliga politiker har ett brett stöd bland allmänheten (Markussen 2004). Jungerstam-Mulders (1999) tolkar kvinnors underrepresentation som en möjlig effekt av att en relativt stor andel bonde- och fiskarbefolkningen dröjer kvar vid en tradi-

\footnotetext{
${ }^{61}$ Redan 1945 introducerades lagstiftning mot könsrelaterad lönediskriminering för vissa yrkesgrupper i Island. Från och med 1995 är lagen om jämställdhet och lika rättigheter för kvinnor och män en del av den isländska konstitutionen.

${ }^{62}$ Se också Einarsdóttir (2004a) "Varför dröjer jämställdheten? Lärdomar av den feministiska våren i Island 2003”, NIKKmagasin 2, 8-10.
} 
tionell könsmässig arbetsdelning, vilken delvis av praktiska skäl hindrar kvinnor från att delta aktivt i politiken i större skala. Som en ytterligare indikation på kvinnors undanskymda politiska tillvaro och svaga maktställning utgör den grönländska delen av den danska maktutredningen ett tydligt exempel (Winther et al 2003a). Trots att det övergripande syftet med utredningen är att belysa innebörden av makt och demokrati i Grönland diskuterar inte någon av maktutredningens medförfattare de könsmässiga dimensionerna av klass, etnicitet, väljardeltagande, välfärspolitiska frågor som arbetsmarknad och utbildningssystemet eller politiska eliter. Inte heller den grönländska utredningen Uden erhversudvikling - ingen velfcerdsudvikling (2003) i vilken många problem och föreslagna lösningar säkerligen berör kvinnor men där kvinnors arbetsmarknadsmässiga situation eller plats i ett grönländskt välfärdssamhälle endast omnämns indirekt.

Vad som i någon bemärkelse kan betecknas som kvinnopolitiska frågor har i varierande grad givits utrymme i de västnordiska välfärdspolitiska debatterna under 1990-talet. I Grönlands jämställdhetsråd har de mest framträdande frågorna kommit att röra mäns våld mot kvinnor och dess effekter på barn och unga, den stora andelen oönskade graviditeter och därmed den höga abortfrekvensen. Till grund för en offentlig debatt presenterade jämställdhetsrådet under 1999 resultaten från en enkät kring grönlänningars attityder till jämställdhet på arbetsplatser, i politiken och i familjen. Här framkommer en bild som i mycket återspeglar könsarbetsdelningen i Europa. Bland annat är den traditionella arbetsdelningen i hemmen är relativt stark, kvinnor är mer missnöjda än män över arbetsdelningen, män är mer tillfreds än kvinnor med graden av jämställdhet och med karriärsmöjligheterna i arbetslivet och trots att män har längre arbetstid anger framförallt kvinnor tidsbrist som orsak till kvinnors lägre politiska deltagande men anser i högre grad än män att det politiska arbetet skulle gynnas om fler kvinnor deltog (Ligestilling i Grønland 1999). Samtidigt som ojämlika könsrelationer i olika sfärer av det grönländska offentliga och privata samhällslivet har kommit att uppmärksammas allt mer har man i jämställdhetsarbetet aktivt och uttalat försökt att hålla den västerländska (eller nordiska) feminismens argument, syn på könsrelationer och förslag till lösningar utanför jämställdhetsdebatten och vad som uppfattas som specifika grönländska förhållanden (Kahlig 2005). Orsaken ligger i en förståelse av grönländska kvinnor som existerande under en 
dubbel underordning vis a vis å ena sidan den danska kulturens etniska, värderingsmässiga och moraliska dominans och å andra sidan den grönländska manliga politiska och ekonomiska dominansen (Rasmussen 2004). Trots det påminner de könsstrukturer som uppträder starkt om de mönster som framträder i övriga Norden och i världen i stort. Identifieringen av den "dubbla underordningen" påminner starkt om den som brukar diskuteras i studier av bland andra afroamerikanska kvinnor och kvinnor som lever under postkoloniala förhållanden. Den grönländska feminismens framväxt och förklaringsmodeller kan därför bli mycket intressanta att ta del av eftersom de kanske kan utveckla ytterligare dimensioner i analyser av relationer mellan kön, etnicitet och makt.

För Färöarnas del har det under det sista årtiondet skett en hel del, betald föräldraledighet infördes 2002 och barnomsorgen är under kraftig utbyggnad. Via det politiska systemet har det offentliga och arbetsgivare tagit på sig ett ökat ansvar för omsorg och erkänner, åtminstone till del förvärvsarbetande föräldrar som arbetskraft. Det framgår också av den nationella statistiken att kvinnor är underrepresenterade i lagtinget, att behov av ytterligare barnomsorg finns, ett antal hushåll erhåller ekonomiskt bistånd på grund av brist på barnomsorg och/eller låg familjeinkomst, att sociala utgifter till arbetslösa kvinnor överstiger de utgifter man har för arbetslösa män samt att våld mot kvinnor och barn medfört ett visst offentligt ekonomiskt stöd till ett kvinnohus och skyddat boende (Árbók fyri Føroyar 2004, 70, 242, 253). Den forskning kring kvinnopolitiska frågor i Färöarna som finns dokumenterad hanterar i huvudsak det färöiska politiska systemets uppbyggnad, valdeltagande och kvinnors mobilisering via kvinnolistor för att öka kvinnors politiska representation (Jákupsstovu 1996, Jákupsstovu kommande).

I Island är den politiska situationen lite annorlunda. Missnöje med det politiska gensvaret på framförallt kravet på föräldraledighet gjorde att ett specifikt kvinnoparti, Kvinnolistan, ställde upp i alltingsvalet 1983 (Rafnsdóttir 1995). Partiet kom att utgöra en viktig påtryckningsfaktor på övriga partier i frågan och rätten till föräldraledigt för kvinnor utökades från tre till sex månader. År 2000 genomfördes ytterligare en förändring i föräldraförsäkringen som i betydande utsträckning kom att innefatta fäders rätt till föräldraledighet med ersättningsnivåer i paritet med förvärvsinkomst. Även om lika många kvinnor som män kandiderar till de allmänna valen utgjorde kvinnor efter valet 1995 endast en fjärdedel av de 
valda representanterna. Vid valet 1999 steg andelen kvinnliga alltingsledamöter till knappt 35 procent för att därefter minska till 30 procent vid valet 2003. I de lokala valen är variationen mellan kommunerna mycket stor men i genomsnitt utgjorde kvinnliga kommunalpolitier endast 28 procent (Women and Men in Iceland 2004). Framförallt när det gäller synen på det offentligas roll i stödet till förvärvsarbetande föräldrar beskrivs Island som en eftersläntrare (Eydal 2000). En hel del genusorienterad forskning pågår varav stora delar är relaterade till välfärds- och arbetsmarknadsforskning och strukturella skillnader mellan kvinnor och män. De främsta forskningspolitiska frågorna gäller de stora löneskillnaderna mellan kvinnor och män och dess koppling till könsdiskriminering, föräldraskap och arbetsmarknad (Einarsdóttir et al 2002). Här skulle man också kunna tillägga att skandinavisk- eller engelskspråkiga studier av aspekter på socialförsäkringssystemens könsmässiga och klassmässiga effekter i stora delar saknas. Sedan slutet på 1990-talet har en isländsk sexindustri med sexklubbar och prostitution vuxit. Den framväxande sexindustrin och könshandeln, kopplad till internationell trafficing och våld, har lett till en offentlig rapport om prostitution och till vissa lagändringar bland annat när det gäller arbetstillstånd men i övrigt framstår, enligt Nilsson (2001), det politiska intresset som ganska svagt. ${ }^{63}$

Det framstår i Västnorden, kanske i likhet med övriga Europa idag, som att krav på politisk förändring kommer från framförallt den akademiska genusforskningen och dess mer löst sammansatta feministiska rörelser snarare än från mer "folkligt förankrade" organisationer och politiskt definierade kvinnorörelser. Ett viktigt forskningsområde vore därför att studera hur institutionaliserad kvinnorörelsen är, vilka typer av krav som kommer från olika grupper och hur dessa krav formuleras. Vilka likheter uppvisar de nordiska länderna och vilka är brytpunkterna mellan politiska krav från olika politiska kvinnorörelser, organisationer med i huvudsak kvinnliga medlemmar och den akademiskt präglade genusforskningen i hela Norden?

\footnotetext{
${ }^{63}$ Enligt Elin Reinert Planck, engagerad i Kvinnohuset i Torshavn, har även Färöarna sedan några år tillbaka fått erfara en ökad tillgång till den europeiska sexindustrin med striptease som den mest synliga uttrycket. Reinert Planck menar att även om det färöiska parlamentet har markerat en restriktiv linje i förhållande till pornografi är delar av dess uttrycksmedel svåra att förhindra eftersom polisväsendet i Färöarna står under den danska staten, vilken har en mer tillåtande lagstiftning (Reinert Planck 2004).
} 


\section{Slutsatser}

De västnordiska länderna liknar länderna i östra Norden bland annat såtillvida att pensionsåldern är relativt hög för både kvinnor och män, kvinnors förvärvsarbete är ganska omfattande och social service erbjuds främst via offentliga institutioner. Ur vissa aspekter förefaller de västnordiska länderna att välfärdspolitiskt skilja sig något från vad som brukar betecknas som den nordiska modellen. Osäkerheten i materialet gör det dock svårt att inom ramen för detta arbete säga om det finns några argument för att säga att de västnordiska välfärdssystemen skulle utgöra en specifik västnordisk välfärdsmodell. Snarare är det så att de västnordiska länderna både har ärvt, överfört och omvandlat välfärdspolitiska idéer och instrument från såväl den nordiska som den liberala och den korporativa modellen i en mix som till viss del avviker från de övriga nordiska ländernas system. De härrör dessutom från ett politiskt arbete som påbörjats långt senare än i övriga Norden och som till del utgår från andra förutsättningar än vad som varit fallet i östra Norden. Bland annat skiljer sig befolkningsstruktur, geografiska förutsättningar och tillgång till naturresurser markant från länder som Danmark, Finland, Norge och Sverige. De grundläggande elementen i de västnordiska socialförsäkringssystemen, så som arbetslöshetsförsäkring, sjukförsäkring och pension, utgörs i de västnordiska länderna delvis av behovsprövade bidrag med jämförelsevis låga ersättningsnivåer. Utformningen av pensions- och arbetslöshetsförsäkringar har också, liksom i övriga Norden, kommit att kombineras med yrkesrelaterade eller privata försäkringar. Dessa är dock närmare knutna till löntagar- och arbetsgivarorganisationer med vertikala lojalitetskrav och är kanske därmed, utifrån klassmässigt mer horisontella aspekter, mer splittrade och mindre samarbetsbenägna. Dess upplägg och bristande tillgång till data försvårar en allmän överblick över hur utfall av pensions- och arbetslöshetsförsäkringar fördelas i befolkningarna. 
Möjligheter till sambeskattning utgör möjligen ett tänkt inslag av en mer kontinentalt inriktad välfärds- och familjepolitik där den ekonomiska och normativa betydelsen av en manlig familjeförsörjare stärks via skattesubventionerande komponenter och bidrag för omsorgsansvar. För Färöarnas del pekar denna del av individbeskattning också på betydelsen av små familjeföretag i vilka båda makar är involverade. Vissa data, framförallt från Grönland, antyder ändå att sambeskattning fyller en något oväntad funktion, nämligen att det framförallt är vissa grupper av kvinnor som erhåller skattelättnader som huvudinkomsttagare och ekonomiska familjeförsörjare. Det är därmed inte klart i vilken mån sambeskattning spelar någon egentlig roll för en familj med en respektive två normalinkomster. Med undantag för föräldraförsäkringen, som erbjuder ersättningsnivåer nära nog i paritet med inkomster från förvärvsarbete, erbjuds medborgare universella rättigheter men taket för maximal utbetalning står i paritet med en minimilön för en icke facklärd arbetare och i flera fall är tillträdesreglerna delvis exkluderande eftersom ett flertal av bidragssystemen är behovsprövande så att de främst är tillgängliga för individer och familjer med små eller mycket små ekonomiska resurser.

Som utmärkande för den nordiska modellen brukar en politisk strävan att minska ojämlikheter mellan skilda befolkningsgrupper på basis av kön, ålder, klass, familjesituation och etnicitet understrykas. En kombination av aktiv arbetsmarknadspolitik kopplad till yrkesorienterade utbildningssystem, hög kvalitet på offentlig service och starka inslag av ekonomisk omfördelning har här varit bland de mest framträdande verktygen. I de västnordiska områdena förefaller de välfärdspolitiska strategierna ha varit något annorlunda. Vid sidan av den offentliga hälsovården har dubbla system liknande de kontinentaleuropeiska vuxit fram i första hand i Island och Färöarna (i något mindre grad i Grönland) inom vilka de som är i arbete åtnjuter betydligt högre ersättningsnivåer än de som under en längre tid befinner sig utanför arbetsmarknaden eller lever med mycket låga förvärvsinkomster. I den mån man kan tala om en västnordisk modell förefaller det som att man, i varje fall under 1990-talet, delvis har vinnlagt sig om en kostnadsreducerande och mer passivt orienterad handlingsstrategi med selektivare omfördelningssystem, främst inriktade på behovsprövade särskilt behövande grupper med svag arbetsmarknadsanknytning. Parallellt med detta system löper ytterligare ett genom vilket 
grupper med fastare förankring på arbetsmarknaden erhåller ersättningsnivåer i höjd med sina tidigare löneinkomster.

Den sociala omsorgsservicen kan till sin struktur liknas vid systemen i östra Norden. Offentligt finansierad barnomsorg har under 1990-talet byggts ut kraftigt i Färöarna och Island och omfattar idag en majoritet av barnen. ${ }^{64}$ Det tyder på en förändrad arbetsmarknad och att förutsättningar för kvinnors ökande förvärvsfrekvens i stigande grad ses som ett politiskt ansvarsområde snarare än enskilda kvinnors eller familjers frivilliga val. Inom ramen för detta projekt har det varit svårt att identifiera trender och att tolka argumenten och riktningarna för de tre ländernas välfärdspolitik, många förändringar har skett under 1990-talet och det är oklart om det vi ser idag enbart är akuta svar på de ekonomiska förhållanden som rådde under slutet av förra seklet eller om de västnordiska länderna på ett mer fundamentalt sätt slagit in på de välfärdspolitiska vägar som de kommer att befästa över tid.

Att betrakta förvärvsfrekvens och ökande sociala utgifter som de huvudsakliga välfärdspolitiska problemen är att förbigå flera viktiga frågor, bland andra frågan om ekonomisk och social omfördelning av resurser, frågan om priset på arbete och diskussioner kring välfärd i en vidare bemärkelse. Det är inte givet att låg arbetslöshet och högt arbetsmarknadsdeltagande i sig reducerar fattigdom på ett mer övergripande plan. Lika lite indikerar låga arbetslöshetssiffror med självklarhet att förvärvsarbetande individer inte lider brist på ekonomiska resurser, lever under olika typer av privata beroendeförhållanden eller med kompletterande stöd från de generella välfärdssystemen. Till exempel kan låga löner, ickeformaliserade anställningar och marginaleffekter av beskattnings- och bidragssystem bidra till att vissa grupper, trots högt arbetsmarknadsdeltagande och med kanske ett flertal olika anställningar, ändå är att betrakta som fattiga och resurssvaga. De kan ha svårigheter att finna mer långvariga, säkrare och bättre avlönade anställningar. Därmed förfogar de inte heller alltid över de medel eller förutsättningar som ger tillträde till olika socialför-

\footnotetext{
${ }^{64}$ Äldreomsorgen har inte kunnat behandlas inom ramen för detta arbete. Det framgår dock av den statistiska informationen att kostnader för vård av nära anhöriga är en ökande utgiftspost, både när det gäller ersättningar till vårdande familjemedlemmar och utgifter för åldringsvård. Täckningen för barnomsorg i Grönland är oklar men Winther (Strategi for dansk-grønländsk polarforskning 2003-2007) påpekar att en viss otillräcklighet inom den befintliga barnomsorgen leder till att föräldrar kan känna oro för sina barn under den tid de förvärvsarbetar. För en närmare studie av äldreomsorgsforskning i Norden, se Szebehely (red) Tema Nord 2005:58.
} 
säkringssystem. ${ }^{65}$ Många problem är förknippade med att alltför avgränsat studera relationen mellan personer i arbetsför ålder och personer som av olika skäl befinner sig utanför den formella arbetsmarknaden. Dels kan skälen till att människor inte står till arbetsmarkandens förfogande variera och behöver inte med nödvändighet vara förknippade med fattigdom eller andra typer av exkluderande effekter, dels förbises lätt andra välfärdspolitiska mål så som till exempel de utbildnings- och regionalpolitiska.

\subsection{Arbetskraft och arbetsmarknad}

Förvärvsfrekvensen är relativt hög bland både kvinnor och män i Västnorden men den varierar betydligt beroende på ålder, civilstatus, utbildningsnivå och bostadsort. Arbetsmarkandens utseende i kombination med de välfärdspolitiska handlingslinjerna väcker ett antal nya frågor. Den socioekonomiska sammansättningen av de grupper som emigrerar är oklar men av den nationella befolkningsstatistiken kan uttolkas att underskottet bland framförallt kvinnor i arbetsför ålder är särskilt tydligt i Grönland och, om än i något mindre utsträckning, även i Färöarna. De interna migrationsströmmarna har också ökat markant och även inom dessa grupper är det kvinnor som utgör den största andelen. Inom den nordiska modellen har ett av argumenten för en relativt generös arbetslöshetsersättning (och i kombination med statlig regionalpolitik) varit att man inte finner några direkta samband mellan den höga ersättningsnivån och antalet arbetslösa och att arbetslöshet framförallt är en effekt av brist på arbetstillfällen, alternativt att sammansättningen av arbetslösa inte är kompatibel med de arbetstillfällen som står till förfogande. Ett grundantagande är därför att en hög ekonomisk ersättningsnivå i arbetslöshetsförsäkringen inte utgör någon direkt attraktionskraft i konkurrens med lönearbete och att ersättningen främst är ämnad att fungera som ett slags övergångsstöd vid behov av flytt, omskolning eller vidareutbildning. Av de resultat som framkommer från den västnordiska befolkningsstatistiken understryks behovet av att närmare analysera den socioekonomiska betydelsen av och sambandet mellan kön, ålder, utbildningsnivå och flyttmönster. Flyttar människor på grund av arbetsbrist och låga ersättningsnivåer eller finns andra mer betydelsefulla skäl? I vilken utsträck-

\footnotetext{
${ }^{65}$ Se t ex Ehrenreich 2002, Saraceno 2003, Kamerman et al 2003, Wall och São José 2003.
} 
ning utgör människors migrationsmönster ett resultat av en västnordisk arbetsmarkandspolitisk strategi eller är migrationsmönster helt enkelt effekter av brist på nationella arbetsmarknads, - regional- och/eller socialpolitiska instrument? Västnordiska medborgare som emigrerar tar sig företrädesvis till Danmark eller något av de övriga nordiska länderna. Utgör välfärssystemen i östra Norden i sig en attraktionskraft och motivationsgrund för personer som flyttar bort från de västnordiska områdena, och då i främst från Färöarna och Grönland, eller är det i första hand utbildningsmöjligheter eller arbetsmarknad som tilltalar migranter som efter utbildning eller en tid av arbete utomlands planerar att återvända till sina hemländer? En mer täckande bild behövs av de faktiska arbetsmarknaderna och arbetsförhållandena inom de västnordiska länderna och över de migrationsmönster som finns. Vilka flyttar? Vart flyttar de och vilka skäl anger de till att de flyttar? Kan olika strategier utläsas bland olika migrationsgrupper? Vilka är återvändarna, vilka är deras motiv att återvända och vilka typer av resurser medför de till hemlandet? Frågorna innefattar såväl demografiska som kulturgeografiska forskningsområden, vilka skulle kunna kombineras med statsvetenskapliga, nationalekonomiska och sociologiska frågeställningar.

Från Grönland rapporteras arbetsmarknadsrelaterade inlåsningseffekter, bland annat på grund av mismatch mellan den kompetens som efterfrågas på arbetsmarknaden och människors utbildningsnivå och andra kunskaper och erfarenheter. Ytterligare en typ av inlåsningseffekt beskrivs också, nämligen den kring balansgången mellan att dra fördel av delar av det danska arvet och samtidigt bygga upp en självständig nation baserad på grönländska värderingar, traditioner och kunskaper. I vilken mån har de självstyrande områdena övertagit danska regelverk och administrationskultur och var uppstår det tolknings- och tillämpningsproblem? Liknande erfarenheter antyds även från färöiskt håll medan Island, på grund av både sin befolkningsstorlek och tiden som självständig nation, inte uppvisar lika tydliga tendenser till generationskonflikter och friktioner mellan vad som efterfrågas på arbetsmarknaden och människors möjligheter att finna arbete. I de bilder av de västnordiska områdena som framträder kan ett antal olika inlåsningseffekter skönjas varav till exempel relationen mellan arbetsmarknad och utbildning samt mellan bidragsoch beskattningssystem och inkomster från förvärvsarbete för individer och familjer bör studeras närmare. 
Vilka är effekterna av de pensionssystem som är under uppbyggnad på delar av de västnordiska arbetsmarknaderna? Hur ser regelverken ut för relationen mellan arbetsgivare, anställningstid och pensionsrättigheter? Vilka konsekvenser medför dessa system för de västnordiska arbetsmarknaderna och för medborgarna? Den typ av pensionssystem som är under uppbyggnad i Färöarna, Grönland och Island skulle kunna innebära att vissa personer gynnas av att stanna hos en arbetsgivare under längre perioder för att därigenom maximera sin pensionsförsäkring. Om så är fallet medför det sannolikt en viss tröghet på arbetsmarknaden. Delar av befolkningarna kommer att möta svårigheter att finna de åtråvärda och mer beständiga anställningar de önskar medan andra kan tänkas bli mindre benägna att byta arbetsgivare.

Ytterligare aspekter på inlåsningseffekter är eventuella samband mellan olika bidragssystem. I vilken grad rör sig personer, som av olika skäl hamnat utanför arbetsmarknaden, mellan de olika systemen? Hur stor andel av arbetslösa eller sjukskrivna övergår, efter en arbetslöshets- eller sjukskrivningsperiod, till att finna sin ekonomiska utkomst via socialbidragssystemet eller förtidspensioneras? I förlängningen kanske det vore möjligt att studera de mekanismer som kan antas påverka marginaliseringar av vissa grupper. I vilken utsträckning utgör till exempel bristande tillgång till offentlig service ett hinder för framförallt kvinnors förvärvsarbete? Kan brytpunkter identifieras för marginaleffekter av sambeskattning och som gör att vissa grupper av framförallt kvinnor avhåller sig från förvärvsarbete av familjeekonomiska skäl? Förändringar av arbetsmarknaderna i riktning mot fler serviceyrken påverkar behovet av välfärdspolitik som tar upp vad som traditionellt brukar kallas kvinnofrågor. Dessa brukar framförallt fokuseras på eventuella behov av social service och arbetsmarknadslagstiftningar till skydd för yrkesverksamma kvinnor vid graviditeter och barnafödande. Ett ökande utbud av social service och en starkare närvaro av kvinnor inom offentlig sektor har i övriga Norden bidragit till attitydförändringar i omsorgsfrågor och till att fler kvinnor engagerar sig politiskt och möter ett större gehör för frågor av denna art. Skulle en utveckling av till exempel ett föreslaget lönesubventionssystem i Grönland kunna vara ett medel att få den stora andelen arbetslösa lågutbildade ut i förvärvsarbete? 


\section{Hälsa och välfärd}

Självfallet är det svårt att bedöma om hälsoproblem är en effekt av marginaliseringseffekter på arbetsmarknaden eller om kausaliteten är tvärt om, det vill säga att hälsoproblem i förlängningen leder till svårigheter att bibehålla ett arbete. Klart är i varje fall att det på både Grönland och Island finns tydliga indikatorer på att hälsofrågor kan kopplas till individers sociala och ekonomiska svårigheter. Liksom i Sverige tyder den geografiska variationen av förtidspensioneringar på att delar av socialförsäkringssystemen korrelerar med andra arbetsmarknadspolitiska problem så som strukturella förändringar på arbetsmarknaden, regional arbetslöshet samt köns- och åldersstrukturer. Möjligen kan just hälsofrågor fungera som den inkörsport till forskning kring välfärdsstater som fram till nu blivit förvånansvärt lite utnyttjad som analytisk infallsvinkel och empirisk informationskälla. Ohälsa bland barn och dokumenterad vanvård av barn visar att innebörden av social och ekonomisk marginalisering har effekter som sträcker sig utöver strikt arbetsmarknadspolitiska eller välfärdspolitiska frågor i en snävare bemärkelse. Det allt mer väldokumenterade våldet mot kvinnor utgör också ett viktigt forskningsområde. Liksom i övriga Norden är det de diskuterade orsakerna till mäns våld mot kvinnor frågor som möter motstånd och känslomässigt laddade diskussioner. Grönland är det land där folkhälsoproblemen är mest omfattande och där man också tydligast idag försöker ta ett helhetsgrepp på sambanden mellan samhällsutveckling och folkhälsofrågor. Fler studier behövs för att identifiera möjliga sociala, kulturella och miljöbetingade orsakssamband och ge förslag på möjliga metoder för att reducera olika riskgruppers utsatthet. Tillgången finns till omfattande dataregister och här finns också stora möjligheter till internationella samarbeten.

Framförallt Färöarna och Grönland och delvis även Island kan betraktas som relativt nya och sent industrialiserade välfärdsstater. Deras ekonomiska och politiska förutsättningar skiljer sig i mångt och mycket från övriga Norden. Som framgått finns också betydande olikheter mellan områdenas politiska historia och framväxten av de befintliga socialförsäkringssystemen. Trots den historiska anknytningen till Danmark och Norden har de västnordiska välfärdsstaterna utvecklats i en delvis annorlunda riktning. Det pekar mot den stora betydelsen av ekonomiska förutsättningar och aktiva politiska vägval snarare än mot att en nordisk eller dansk modell har implementerats som en historisk följd av dansk över- 
höghet eller täta politiska kontakter med övriga nordiska länder. Den politiska strukturen i de västnordiska länderna skiljer sig från östra Norden. De tydligaste tecknen är att den politiska vänstern i Färöarna och Island varit jämförelsevis svag och att nationalistiskt inspirerade självständighetspartier samtidigt har haft ett påtagligt inflytande både $\mathrm{i}$ Färöarna och i Island. För Grönlands del är de välfärdspolitiska tendenserna mer oklara eftersom självständighetssträvanden där finns i en tydligare danskinspirerad organisatorisk och politiskt starkare socialdemokratisk sfär. Till de gemensamma karaktärsdragen för de västnordiska områdena kan också fogas den svaga kvinnorepresentationen i de folkvalda organen. Frågan är i vilken mån de arbetsmarkandsmässiga omstruktureringarna, sociala och ekonomiska förändringar och effekter av globaliseringstendenser inom olika områden leder till behov av välfärdspolitiska revideringar och hur dessa i så fall formuleras. Önskar de västnordiska områdena vidareutveckla sin nuvarande "slimmade" välfärdsmodell eller är de på väg att bygga upp modifierade modeller av den nordiska? Vilka olika slags politiskt impregnerade historiska vägvalsberoende beslut kan identifieras? Den socioekonomiska sammansättningen av makteliter medför att frågan om välfärdspolitiska handlingslinjer inte är helt okomplicerad, inte minst eftersom den nordiska modellen betraktas med viss misstänksamhet i de västnordiska länderna, samtidigt som det inom Färöarnas och Grönlands politiska fält finns både de som är för och de som är emot en strävan efter nationell suveränitet. Hur är makteliterna i de västnordiska länderna sammansatta? Hur byggs tilliten inom dessa upp och vilka normativa, sociala och ekonomiska komponenter ingår i det som skulle kunna kallas sociala kapital? Vilka politiska och ekonomiska frågor driver de och vad möter de för motstånd bland andra grupper i befolkningarna? Hur ser västnordiska medborgare på sina länders välfärdspolitiska framtid? Vilka attitydmönster finns representerade bland befolkningarna när gäller jämlikhet och jämställdhet, syn på och tilltro till välfärdssystemen och de politiska ledningarna? Till den diskussionen skulle ett flertal aspekter kunna läggas kring hur representationen av könspolitiska och klassmässiga frågor har representerats och hanterats i relation till såväl politiska som ekonomiska makteliter och i förhållande till hur ekonomiska och välfärdspolitiska frågor har behandlats under olika epoker under efterkrigstiden. 
Vad som fordras för att kunna studera, utvärdera och diskutera konsekvenser och förutsättningar för västnordiska välfärdsstater och västnordisk välfärdspolitik är framförallt jämförbara statistiska databaser. Det fordras också överskådlig information om socialpolitiska riktlinjer och regelverk. Med hjälp av dessa kan jämförande studier i respektive välfärdssystems effekter på sociala och ekonomiska strukturer på såväl makro- som mikronivå inledas. Ytterligare ett studieområde är kartläggningar av politiska och ekonomiska maktrelationer, målsättningar och strategier. 
84 Välfärdspolitiska förhållanden i Västnorden - Färöarna Grönland och Island 


\section{Summary}

The Nordic welfare state model is characterized by high labour market participation rates among both men and women, universal principles for the distribution of social rights, relatively high compensation rates, an encompassing public service sector and limited individual dependency on economic support from the family. Despite the fact that the Faeroe Islands, Greenland and Iceland are geopolitically part of the Nordic countries, they are seldom included in international comparative welfare studies. Nevertheless, some analyses indicate that welfare policies pursued in these western Nordic regions differ from the welfare policy features of the eastern Nordic countries. This report provides an overview of up-todate available social-scientific reports and texts connected to welfare studies that focus on the western Nordic countries. Moreover, welfare political indicators in a wider sense from the Faeroes, Greenland and Iceland are compared to identify both country specific as well as common traits in the shaping of their welfare systems. Conclusions drawn from past and current studies are presented and results of a more general character are pointed out. Prominence is also given to findings that indicate more specific features of the western Nordic societies.

The design of the western Nordic welfare political programs, specifically those concerning different types of social insurances, are briefly described and compared. Conclusions are primarily intended to stimulate future research questions and country specific and comparative studies. Only texts available in Scandinavian languages or in English have been used. The materials included consist of reports, research results and analyses along with official statistical material and publications. In addition, texts and material published on the Internet have been utilized. Some of the information is based on own calculations from these sources and are hence to be considered as indicative. 
The welfare political circumstances in the western Nordic region both resemble and diverge from the rest of the Nordic countries. The social insurance systems are mainly publicly financed and universal in a way similar to that of the eastern Nordic countries. With a few exceptions, the compensation rates are low in comparison with the Danish, Finish, Norwegian and Swedish welfare systems. The importance of the circumstances hedging the labour force in the fishing industry is suggested as one possible explanation to the limited compensation rates based on household composition, rather than having individual rights as outset for certain allowances, subsidies and pensions. Furthermore, official expectations are that individuals earn a certain degree of alternative maintenance and income from activities such as fishing, hunting, own cultivation and livestock as well as barter economies, which suggest a reduced need for public economic support. Hence, while economic poverty can be considerable, people may have other means to provide certain individual and family needs. Economic poverty is strongly related to various aspects of public health, particularly in the case of Greenland.

The participation rates of Faroese and Icelandic men and women in the labour market labour market are higher than in the eastern Nordic countries. There is a considerable difference between men's and women's incomes which is related to gender segregated labour markets and to larger numbers of women in part-time employment. Women's lower incomes are reflected in their dominating number among single parents' receiving social allowances. In comparison to earlier social insurance systems with limited connection to the individual's previous incomes, the more recently introduced ones, such as the Faroese and Icelandic parental leaves, are constructed to offer full replacement levels for loss of income from work. Social services, childcare facilities in particular, have expanded during the 1990s and are accessible on terms similar to those of the eastern Nordic countries. The demographic structure of Greenland, the Faeroe Islands and Iceland depict young populations and, in comparison to Denmark, Finland, Norway and Sweden, a large share of persons above the retirement age are still employed. The question arises as to whether the explanation for this lies in lifestyles, cultural or ideological aspects, or whether the main cause has economic motives. An additional facet that is brought to the forefront within the scope of the project is the importance of the possibility of joint taxation for men's and women's 
labour market participation. A question that arises is to what degree joint taxation limits or stimulates paid work among individuals within different income groups?

No larger national or comparative western Nordic welfare studies or socio-political evaluative research results are yet available, but official figures indicate market differences in health and income between low and high skilled individuals, between younger and elderly persons, inhabitants in towns or in rural areas of the Faroese Islands, Greenland and Iceland and between native-born groups and immigrants. The patterns indicate cultural, social and economic relationships that partly differ from the other Nordic countries. Being an immigrant or having a higher education preferably obtained in an eastern Nordic country, has until today implied access to better paid jobs, especially in Greenland. The countries find themselves at a critical point in which an increasing number of young persons are in search of regular employments with fixed incomes, while a decreasing number of persons continue to earn their living through selfsubsistent household combined with periodical employment, primarily within the fishing industries. These changes pose new challenges to the western Nordic welfare systems. Concerning the systems for taxation and the social insurance policies, national and comparative studies should be done with the aim to identify built-in segregation and poverty traps related to marginal tax rates and within the design of the social security systems. Also the shaping of welfare and labour market policies should be examined in closer detail in order to pinpoint confining effects as well as the relationship between economic conditions, migration patterns, education and retraining possibilities and labour supply.

Existing research from the western Nordic areas points to the fact that forceful economic and political investments in the fishing industry in combination with under-investments in other areas of research and development, such as the development of the conditions and prerequisites within new sectors, have brought on gaps or mismatch in welfare politics and economics. Partly due to the small populations, the dominance of the fishing industry as the main source of revenue and export commodity, and the Faroese and Greenlandic relationships to Denmark, several reports underline the importance of local and national economic power elites. It is argued that these factors have influenced the western Nordic societies in ways that appear to diverge from the welfare political rationa- 
le of the eastern Nordic countries. Hence, a further area that deserves more attention is the interrelationship between vested economic interests, wider interest groups and the role of the state in issues such as national economic and socio-political preferences and priorities. To what degree do state initiatives in the Faeroe Islands, Greenland and Iceland also feature elements of self-interests promoted by special interest groups? Given the geographical, demographical and economic conditions, combined with today's constellations of economic and political power relations, what are the possibilities for the western Nordic countries to plan and act on a long-term basis? In addition, more studies are required that address the ways in which the Faroese and Greenlandic home rules and Denmark exercise political and economic power. Furthermore, the alternative ways in which the political systems of the western Nordic countries may strengthen their legitimacy deserve attention, not least in relation to the social and economic capital of various groups and possible future socioeconomic and structural conflicts. 


\section{Referenser}

Adolphsen, Jes och Tom Greiffenberg (1999) "Social Democratism and the Development of Greenland”, i Pedersen, Hanna och Birger Poppel (red.) Dependency, Autonomy, Sustainability in the Artcic. Aldershot: Ashgate Publ. Ltd, 143-149.

Agersnap, Torben (1999) "Social Conditions för Sustainable Development”, i Pedersen, Hanna och Birger Poppel (red.) (1999) Dependency, Autonomy, Sustainability in the Artcic. Aldershot: Ashgate Publ. Ltd, sid 91-100.

Allmanna- og Heilsumalastyrid (mars 2002), Færøsk lovgivning omfattet af "Nordisk konvention om Social Sikring” pr. 1. marts 2002.

Andersen, Thomas (1999) "A Circumpolar Study of Living Conditions among Inuit and Saami Populations”, i Pedersen, Hanna och Birger Poppel (red.) (1999) Dependency, Autonomy, Sustainability in the Artcic. Aldershot: Ashgate Publ. Ltd, 303-314.

Andersen, Thomas och Ole Tonsgaard (2003), ”Vælgermagt i Grønland”, i Winther, Gorm (red) Demokrati og magt i Grønland. Aarhus: Aarhus universitetsforlag, 55-79.

Anttonen, Anneli and Jorma Sipilä (1996) "European social care services: Is it possible to identify models?”, Journal of European Social Policy, No. 6, Vol 2, 87-100.

Apostle, Richard, D. Holm, G. Hovgaard, Ó. Waag Høgnesen, B. Mortensen (2002) The Restructuring of the Faroese Economy. The Significance of the Inner Periphery, Fredriksberg C: Samfundslitteratur.
Arbejdsmarked 2004:1Ledigheten 2003. Grønlands Statistik. Arbejdsmarked 2005:2Ledigheten i 2004. Grønlands Statistik. Árbók fyri Føroyar 2004, Hagstova Føroya 2004. CD-ROM.

Bergqvist, Christina et al. (1999) Likestilte demokratier? Kjønn og politikk i Norden. Oslo: Universitetsforlaget.

Berntsson LT och L Köhler (2001) "Long-term illness and psychosomatic complaints in children aged 2-17 years in the five Nordic countries. Comparison between 1984 and 1996”. European Journal of Public Health 11, 35-42.

Beskjæftigelsen i Grønland 2002. Arbejdsmarked 2004:2. Grønlands Statistik. http://www.greenstat.gl/. Beskceftigelsen i Grønland 1998 (foreløbige tal) 2000:6, Special publikation, Grønlands Statistik. http://www.statgreen.gl/. 2005-10-28.

Broddadóttir, Ingibjörg et al (1997) "The development of local authority social services in Iceland”. I Jorma Sipilä (red) Social Care Services: The Key to the Scandinavian Welfare Model. Aldershot: Ashgate Publishing Company, 51-76.

Bygren, Magnus, Michael Gähler och Magnus Nermo (red.) Familj och Arbete - vardagsliv i förändring. Stockholm: SNS Förlag.

Christiansen, Niels Finn och Klaus Petersen (2001) “The Nordic Welfare States: A Historical Reappraisal”, Scandinavian Journal of History 26, 153-156. 
Daly, Mary och Rake, Katherine (2003) Gender and the Welfare State. Cambridge: Polity Press.

Edvardsson, Ingi Runar (2001) “Regional labour market performance in Iceland in the 1990s”, i Persson, Lars Olof (red) Local labour market performance in Nordic countries. NordRegio Report 2001:9, 109-133.

Ehrenreich, Barbara (2002) Barskrapad: Konsten att hanka sig fram. Stockholm: Leopard.

Einarsdóttir, Thorgerdur (2003) "Challenging the Slow Motion of Gender Equality - the Case of Iceland”, Paper presenterat vid konferensen Gender and Power in the New Europe, the $5^{\text {th }}$ European Feminist Research Conference, $\mathrm{Au}-$ gust 20-24, 2003 Lund University, Sweden.

Einarsdóttir, Thorgerdur (2004a) "Varför dröjer jämställdheten? Lärdomar av den feministiska våren på Island 2003, NIKKmagasin 2, 8-10.

Einarsdóttir, Thorgerdur (2004b) Culture, Custom and Caring: Men's and Women's Possibilities to Parental Leave. Reykjavik: Centre for Women's and Gender Studies. www.jafnretti.is.

Einarsdóttir, Thorgerdur, Gunnhildur Krsitjánsdóttir, Hildur Fjóla Antonsdóttir och Erla Hulda Haldórsdóttir (October 2002) Towards a closing of the gender pay gap. Country Report. Iceland. Centre for Women Studies, Reykjavik. www.likestilling.no.

Eydal, Gudny Björk (2000) "Nordic childcare policies and the case of Iceland”, i Thomas Bahle och Astrid Pfenning (red) Families and Family Policies in Europe. Comparative Perspectives. Frankfurt am Main: Peter Lang Verlag, 104-126.
Eydal, Gudny och Stefan Ólafsson (2003a) "Demographic Trends in Iceland“. National report number one, for the project Welfare Policy and Employment in the Context of Family Change. May 2003.

http://www.york.ac.uk/inst/spru/res earch/summs/welempfc.htm.

Eydal, Gudny och Stefan Ólafsson (2003b) "Social and Family Policy. The Case of Iceland“. National report number three for the project Welfare Policy and Employment in the Context of Family Change. May 2003.http://www.york.ac.uk/inst/spr u/research/summs/welempfc.htm. Eydal, Gudny, Stefan Ólafsson och Svanborg Sigmarsdottir (2003c) "Labour Supply in Iceland”. National report number two, for the project Welfare Policy and Employment in the Context of Family Change. May 2003. http://www.york.ac.uk/inst/spru/res earch/summs/welempfc.htm.

Faroe Islands in Figures 2003. Statistics Faroe Islands.

Ferrarini, Tommy (2003) Parental Leave Institutions in Eighteen Postwar Welfare States. Avhandlingsserien $\mathrm{nr} 58$, Institutet för social forskning, Stockholms universitet.

Freysteinsdóttir (2004) "Repeated child maltreatment and risk factors in Iceland", Paper presenterat vid Nordiska Ministerrådets Välfärdsforskningsprograms konferens i Torshavn 2-3 september 2004.

Gaini, Firouz (2003) ”Færøerne - et nordatlantisk øsamfunds ungdom” i Helve, Helena (red) Ung i utkant. Aktuell forskning on glesbygdsungdomar i Norden. Tema Nord 2003: 519, Köpenhamn: Nordiska Ministerrådet, 119-137.

Gardberg Morner, Claudia (2000) "Subsistance in an ambivalent welfare state. On lone mothers in It- 
aly”, i Thomas Bahle och Astrid Pfenning (red) Families and Family Policies in Europe. Comparative Perspectives. Frankfurt am Main: Peter Lang Verlag, 245-269.

Gardberg Morner, Claudia (2003) Självständigt beroende. Ensamstående mammors försörjningsstrategier. Göteborg Studies in Sociology No 18. Department of Sociology. Göteborg University. Greenland 2001-2002. Statistikal Yearbook. Nuuk: Greenstat. Greenland in Figures 2002. Statistics Greenland (2002). Greenland Home Rule Government.www.statgreen.gl Greenland in Figures 2003, Statistics Greenland 2003.

Guðmundsson, Sigurður (2004) "Videnskabelig forskning. Sundhetsforhold”. Föredrag hållet vid Nordiska Ministerrådets Välfärdsforskningsprograms konferens i Torshavn 2-3 september 2004. Halldórsson, Matthias et al (2000) "Socioeconomic inequalities in the health of children and adolescents. A comparative study of the five Nordic countries”, European Journal of Public Health 10, 281-288.

Hannibalsson, Jón Baldvin (2004) "Den nordiska välfärdsstaten. En socialt stabiliserande faktor i en förenderlig global ekonomi”. Paper presenterat vid Nordiska Ministerrådets Välfärdsforskningsprograms konferens i Torshavn 2-3 september 2004.

Hantris, Linda (2004) Family Policy Matters. Responding to family change in Europe. Bristol: Polity Press.

Health Statistics in the Nordic Countries 2002 (2004) Köpenhamn: NOMESCO.

Health Statistics in the Nordic Countries 2002. www.nom-nos.dk.
Health Statistics in the Nordic Countries 2003. www.nom-nos.dk.

Helve, Helena (red) (2003) Ung i utkant. Aktuell forskning on glesbygdsungdomar i Norden. Tema Nord 2003: 519, Köpenhamn: Nordiska Ministerrådet.

Hersoug, Bjørn (1997) ”Fra plan til marked - de vest-nordiske fiskerinæringene på 1990-tallet”, i Jonsson, Gudmundur (2001) “The Icelandic Welfare State in the Twentieth Century”, Scandinavian Journal of History 26, 249-267.

Hovgaard, Gestur (2001) Globalisation, Embeddedness and Local Coping Strategies. A Comparative and Qualitative Study of Local Dynamics in Contemporary Social Change. Ph.D. dissertation no 29/2001. Roskilde: Department of Social Sciences.

Hovgaard, Gestur (2002) "Local restructuring - The case of Klaksvík”, i Apostle, R. et al. The Restructuring of the Faroese Economy. The Significance of the Inner Periphery. Fredriksberg C: Samfundslitteratur, 105-122.

Hovgaard, Gestur, Grétar Thór Eythórsson och Katarina Fellman (2004) Future Challenges to Small Municipalities. The Cases of Iceland, Faroe Islands and Åland Islands. Stockholm: Nordregio.

http://www.region.fo/UK/research_pr ojects.html, http://www.setur.fo/.

Huber, Evelyne och Stephens, John D. (2001) Development and Crisis of the Welfare State. Parties and Policies in global Markets. Chicago: The University of Chicago Press.

Iceland in Figures 2003-2004. Statistics Iceland 2003. www.hagstofa.is. Indkomststatistik 1992-2002. Del 2, tabell 2.1, 18. Statistics Greenland 
2004:1. http://www.greenstat.gl/. (2004-11-18).

International Journal of Circumpolar

Health. http://ijch.oulu.fi/

Inussuk. Arctic Research Journal 2000, 2.

Jákupsstovu, Beinta í, (1996) ”Kvinner ingen adgang? Rekruttering av kvinner til bystyret i Tórshavn 1972-1992”, Norsk Statsvitenskapelig Tidsskrift (12) 1, 35-56.

Jákupsstovu, Beinta í, (2003) Kunskap og makt I frerøisk helsepolitik 1820-1970. Avhandling. Bergen: Institutt for administrasjon og organisasjonsvitenska- p: Universitetet i Bergen.

Jákupsstovu, Beinta í, (2004) ”Vestnordiske velferdsmodeller”. Paper presenterat vid Nordiska Ministerrådets Välfärdsforskningsprograms konferens i Torshavn 2-3 september 2004.

Jákupsstovu, Beinta í, (kommande) "Case 5 Faroe Islands: Changing gender relations: Faroese women in new roles, entering the public sphere”. Delrapport till projektet "Women leave...” finansierat av Nordiska Ministerrådets Välfärdsforskningsprogram. www.fifo.no/ genwel/.

Jákupsstovu, Beinta í, och Eli Kjersem (2004) "Rekruttering av færøske kommunpolitikere”, Paper presenterat vid den XIII nordiske kommunlaforskerkonferansen i Oslo 26-28 november 2004.

Joensen, Petra Jonsdóttir (2004) “En belysning af det sociale område på Færøerne og dets utvikling samt en sammenligning med forholdene i de øvrige Nordiske lande”. Paper presenterat vid Nordiska Ministerrådets Välfärdsforskningsprograms konferens i Torshavn 2-3 september 2004.
Jonsson, Gudmundur (2001) "The Icelandic Welfare State in the Twentieth Century”, Scandinavian Journal of History 26, 249-267. Jónsson, Ivar (1995) West-Nordic Countries in Crisis. Neostructurlaism, Collective Entrepeneurship and Microsocieties Facing Global Systems of Innovation. Köpenhamn: Nyt fra Samfundsvidenskaberne. Institut for Organisation og Arbejdssociologi. Handelshøjskolen I Køpenhavn. Jónsson, Ivar (1999a) “From Home Rule to Independence - New Opportunities för a New Generation in Greenland”, i Pedersen, Hanna och Birger Poppel (red.) (1999) Dependency, Autonomy, Sustainability in the Artcic. Aldershot: Ashgate Publ. Ltd, 171-192.

Jónsson, Ivar (1999b) ”Development, learning-processes and institutionalized racism”. Ethnic and Racial Studies, Vol. 22, No. 1, 113-135.

Jungerstam-Mulders, Susanne (1999) "Kvinnorrepresentation och jämställdhet på Färöarna, Grönland och Åland”, Christina Bergqvist mf fl (red) Likestilte demokratier? Kjønn og politikk i Norden. Oslo: Universitetsforlaget, 231-252.

Kahlig, Wolfgang (1999) Leder $i$ Grønland - en kvalitativ holdningsundersøgelse. Nuuk: Ilismatusarfik.

Kahlig, Wolfgang (2002) "Nogle problematikker omkring ledighed og marginalisering i relation til arbejdsmarkedsreformen af 1997”. Grønlands Kultur- og samfundsforskning 2002, 23-34.

Kahlig, Wolfgang (2003) "Samfundsforskning i Grønland set i et magtog perticipationsperspektiv”, i Winther, Gorm (2003b) (red) Demokrati og magt i Grønland. Aarhus: Aarhus universitetsforlag, 236-254. 
Kahlig, Wolfgang (2005) "Ligestillingsområdets institutionaliseringsprocess i Grønland”, utkommer i januar 2005 i Grønlandsk Kultur og Samfundsforskning.

Kamerman, Sheila B, Michelle Neuman, Jane Wadfogel and Jeanne Brooks-Gunn (2003) Social Policies, Family Types and Child Outcomes in Selected OECD Countries. DELSA/ELSA/ WD/SEM(2003)6. Paris: OECD.

Kautto, Mikko (red) (2001) Nordic Welfare States in the European Context. London: Routledge.

Knudsen, Jon P., (2003) Future challanges and institutional preconditions for regional development policy. Nordregio Working Paper 2003: 1. Stockholm: Nordregio.

Kön och våld i Norden. Rapport från en konferens i Køge, Danmark, 2324 november 2001. Nordiska Ministerrådet. Forskning. TemaNord 2002:545.

Labour Market Statistics 2002. Statistics Iceland. http://www.statice. is/?pageID=788. 2005-10-28).

Langgård, Karen (2003) ”Magt og demokrati - og sprog”, i Winther, Gorm (red) Demokrati og magt $i$ Grønland. Aarhus: Aarhus universitetsforlag, 215-235.

Leira, Arnlaug (1992) Welfare States and Working Mothers. The Scandinavian Experience. Cambridge: Cambridge University Press.

Ligestilling i Grønland - En undersøgelse af ligestillingen i hjemmet, på arbejdspladsen og i det offentlige liv. (1999) Ligestillingsrådet $\mathrm{i}$ Grønland. Nuuk. www.nali.gl.

Lundgren, Eva (2004) Våldets normaliseringsprocess. Riksorganisationen för Kvinnojourer och tjejjouren i Sverige (ROKS). Umeå; Brottsoffermyndigheten.
Lundgren, Eva et al (2001) Slagen dam. Mäns våld mot kvinnor $i$ jämställda Sverige - en omfångsundersökning. Stockholm: Fritzes Offentliga Publikationer.

Lyck, Lise (1997a) "Small Nordic Jurisdictions in a Changing World", Bjarne Lindström (red) Den regionala utmaningen: Territoriell politik i ett europeiskt Norden. Nordrefo 1997:8, 193-203.

Lyck, Lise (red) (1997b) Constitutional and Economic Space of the Small Nordic Jurisdictions. NordREFO 1996:6. Stockholm: NordREFO.

Lytthans, Kaspar (1999) "Perspectives in the development of Greenlandic Administration”, i Pedersen, Hanna och Birger Poppel (red.) Dependency, Autonomy, Sustainability in the Artcic. Aldershot: Ashgate Publ. Ltd, 115-125.

Makt att forma samhället och sitt eget liv-jämställdhetspolitiken mot nya mål. Slutbetänkande av Jämställdhetspolitiska utredningen. SOU 2005:66. www.regeringen.se.

Markussen, Gudmunsdóttir Inga Dóra (2004) "Women's Status in Greenlandic Society", paper presented at the Conference on Gender Environment and Societal Development in West Nordic and Arctic Countries. Nov 13-14, University of Akureyri, Iceland. www.jafnretti.is.

Martinussen, Willy (1973) Fjerndemokratiet. Oslo: Norsk Gyldendal.

Meldgaard, Susanne (2003) "Reducing unwanted pregnancies in Greenland”. International Journal of Circumpolar Health, 267-269.

Mingione, Enzo (1995) "Labour Market Segmentation and Informal Work in Southern Europe" European Urban and Regional Studies 2 (2), 121-143. 
MOST CCPP http://uit.no/mostccpp.

Motzfeldt, Jonathan (1997) "Home

Rule in Greenland", i Lise Lyck (red) (1997) Constitutional and Economic Space of the Small Nordic Jurisdictions. NordREFO 1996:6. Stockholm: NordREFO, 192-195.

Motzfeldt, Josef (2004) "Den poliskekonomiske utvickling i Grønland Vejen mot store økonomisk uafhængighed”, Link via Grønlands Hjemmestyres Hjemmeside, http://www.anipi.gl/dokumenter/pol iticaartiklen.htm (hämtat 2004-04-16).

Mørkøre, Jogvan (1997a) “The Faroese Home Rule Model - Theory and Reality”, i Lise Lyck (red) Constitutional and Economic Space of the Small Nordic Jurisdictions. NordREFO 1996:6. Stockholm: NordREFO, 162-191.

Mørkøre, Jógvan (1997b) "Labour Force in a Dual Strategy”, i Lise Lyck (red) The Faroese Economy in a Strategic Perspective. Nordrefo 1997:6, 215-228.

Nilsson, Maria G. (2001) "Island paradoxernas jämställdhetsland”, Jämsides. Jämos tidning $\mathrm{nr}$ 3, 21-24.

Nordenmark, Mikael (2004) Arbetsliv, familjeliv \& kön. Umeå: Boréa Bokförlag.

Nordic Statistical Yearbook 2003. Nord 2003:1. Köpenhamn: Nordiska Ministerrådet.

Näslund, Sture (2000) "På väg mot självständighet? Färöarna, Grönland och Åland”. Världspolitikens Dagsfrågor nr 11. Stockholm: Utrikespolitiska institutet.

OECD (1999) Greenland Economy: A Strategy for the Future. Paris: OECD. DT/TDPC(99)10. www.anipi.gl/dk/publikationer.htm.
OECD (2000) Grølands økonomi: En strategi for fremtiden. Paris: OECD. Oláfsson, Stefán (1999) ”The Icelandic model”. Comparing Social Welfare Systems in Nordic Europe and France. Copenhagen Conference, Vol 4. Paris: MIRE

Ólafsson, Stefán (2003a) ”Welfare trends of the 1990s in Iceland", Scandinavian Journal of Public Health, 31, 401-404.

Ólafsson, Stefán (2004) “Tættest på Amerika eller på Skandinavien?”, i Hur mår den nordiska välfärden?. Nordiska rådets och Nordiska ministerrådets Årsbok 2004. 2004: 761. Köpenhamn: Nordiska rådet och Nordiska ministerrådet, 67-76. Ólafsson, Stefán (maj 2003b) “Normative Foundations of the Icelandic Welfare State. On the gradual erosion of citizenship-based welfare rights”. Kommande kapitel i Stein Kuhnle och Nanna Kildal och Stein Kuhnle (red) Normative Foundations of the Nordic Welfare State. London: Routledge.

Pedersen, Birgit Kleist och Jette Rygaard (2003) "Grønländske Unge mellem Tradition og Globalisering”, i Helve, Helena (red) Ung i utkant. Aktuell forskning on glesbygdsungdomar i Norden. Tema Nord 2003: 519, Köpenhamn: Nordiska Ministerrådet, 272-298. Pedersen, Hanna och Birger Poppel (red.) (1999) Dependency, Autonomy, Sustainability in the Artcic.

Aldershot: Ashgate Publ.

Petersen, Hanne (2003) "Magt og myndigheed - skift og forandringer”, i Winther, Gorm (red) Demokrati og magt i Grønland. Aarhus: Aarhus universitetsforlag, 195-214.

Politiken 2004-11-16. "Folkesundheden I Grønland har det skidt”. http://www.politiken.dk/VisArtikel. 
iasp?PageID=345233.

(2004-11-19).

Poppel, Birger (2004) "Sundhetsforhold i Grønland”, presentation vid Nordiska Ministerrådets Välfärdsforskningsprograms konferens i Torshavn 2-3 september 2004.

Poppel, Mariekathrine (2004) “Domestic Violence - Men’s Violence Against Women”, paper presented at the Conference on Gender, Environment and Societal Development in West Nordic and Arctic Countries, Nov 13-14 2004. University of Akureyri, Iceland.

www.jafnretti.is.

Rafnsdóttir, Guðbjörg, Linda (1995)

Kvinnofack eller integrering som strategi mot underordning. Diskussion kring kvinnliga fackföreningar på Island. Lund Dissertations in Sociology 8. Lund: Lund University Press.

Rasmussen, Henriette (2004) "Kvinder I Grønland”.

http://www.nanoq.gl/udskriv.asp?pa ge $=$ nyhed\&objno=68015. (hämtat 2004-12-14).

Reformerad föräldraförsäkring kärlek, omvårdnad, trygghet. SOU 2005:73. www.regeringen.se.

Reinert Planck, Elin (2004) "Resources for abused women in the Faroe Islands", paper presented at the Conference on Gender, Environment and Societal Development in West Nordic and Arctic Countries, 2004 nov 13-14, University of Akureyri, Iceland.

Rigsombudsmanden på Færøerne. Beretning 2003. Köpenhamn: danmark.dk.

Rygaard, Jette (2003) "Gender differences: reality or history?", NORA (11) 3, 170-182.

Sainsbury, Diana (1996) Gender, Equality and Welfare States. Cam- bridge: Cambridge University Press.

Saraceno, Chiara (1994) "The Ambivalent Familism of the Italian Welfare State”. Social Politics Vol 1, No 1, 60-82.

Saraceno, Chiara (2000) "Italian Families under Economic Stress: The Impact of Social Policies”. LABOUR 14 (1), 161-184.

Saraceno, Chiara (2003) "La conciciliazione di responsibilità familiari e attività lavorative in Italia: Paradossi ed equilibri imperfetti”, POLIS XVII, 2, August, 199-228.

Saraceno, Chiara and Negri, Nicola (1994) "The Changing Italian Welfare state” Journal of European Social Policy 4 (1) p 19-34.

Sigursteinsdóttir, Hjördis (2003) "The Women leave but the Men Remain - Statistics on the Nordic Welfare Model and Gender Relations in Transition - The Icelandic Case”, Icelandic Institute for Reginal Research. Final draft September 2003. http://www.brsi.is/english/wl_ support.htm

Sipilä, Jorma (red) (1997) Social Care Services: the Key to the Scandinavian Welfare Model. Aldershot: Avebury.

Social Protection in the Nordic Countries 2002 http://www.nomnos.dk/nososco.htm (NOSOSCO 2004). 2004-11-05.

Socialförsäkringen Norden. En översikt. (maj 2004) Stockholm: Försäkringskassornas förbund.

Socialstatistik 2004:1 "Modtagere af sociale ydelser 1997-2002”. Grønlands statistik 2004. www.statgreen.gl

Socialstatistik 2004:2 "Modtagere af sociale ydelser 1997-2002 - økonomiske nøgletal”. Grønlands statistik 2004. www.statgreen.gl 
Statistical Bullentin 2000 of the

Faroe Islands. Torshavn: Hagstova.

Statistical Yearbook for Iceland 2003.

Statistics Iceland.

http://www.hagstofa.is/template_db

_frameset_en.asp?PageID=1166\&if

rmsrc=/uploads/files/lh2003/L0314

06.xls\&Redirect $=$ False.

Statistics and Information.

www.ahus.is/FRAMES/ENG/navig/ stats.htm. (2003-03-31).

Statistics Iceland. www.hagstofa.is.

Strategi for dansk-grønlandsk polarforskning 2003-2007. Kommissionen för Videnskabelige Undersøgelser i Grønland.

Sundström, Eva (2000) "Gender attitudes towards female empolyment in Germany, Italy and Sweden”, i Thomas Bahle och Astrid Pfenning (red) Families and Family Policies in Europe. Comparative Perspectives. Frankfurt am Main: Peter Lang Verlag, 200-220.

Szebehely, Marta (red) (2005) Äldreomsorgsforskning i Norden. En kunskapsöversikt. Tema Nord 2005:38.

Sørensen, Bo Wagner (2001) ”'Men in Transition': The Representation of Men's Violence Against Women in Greenland”. Violence Against Women. Vol 7, No 7, 826-847.

Tema 1997:610. "Forskningsaktiviteter på Færøarna och Grønland - Forskningssamarbede i Vestnorden I.” Køpenhavn: Nordisk Ministerråd.

Thorsteinsson, Bendedikte (2004)

“Grønland som 'modtager' av den nordiske velfærdsmodel”, Hur mår den nordiska välfärden? Nordiska rådets och Nordiska ministerrådets årbok 2004. ANP 2004:761, 93100. Köpenhamn: Nordiska Ministerrådet.

Uden Erhvervsudvikling - ingen Velfcerdsutvikling (oktober 2003)
Grønlands Hjemmestyre, Direktoratet for Erhverv. www.nanoq.gl/ naleraq.

Valdimarsdóttir, Fríða Rós (2005) Nordiska erfarenheter av föräldraledigheter och dess inverkan på jämställdhet mellan kvinnor och män. Akureyri: Jafnréttisstova. www.jafnretti.is.

Vogel, Joachim (1997) Living Conditions and Inequality in the European Union 1997. Population and Social Conditions E71997-3. Working Papers Eurostat. Stockholm: Statistics Sweden.

Vogel, Joachim, Birgitte Bröndum, Ingrid Melby och Pekka Ruotsalainen (2004) “Arbetsinkomster och bidrag i de nordiska länderna under 1990-talet”. Paper presenterat vid det högre seminariet 2004-11-19, Sociologiska institutionen, Umeå Universitet, Sverige.

Wall, Karin and José São José (2003) Immigrant Families, Work and Social Care. A qualitative comparision of care arrangements in Finland, Italy and the U.K., France and Portugal. Written for the European Commission. Framework Programme V, Action for SocioEconomic Research. Published at: http://www.uta.fi/laitokset/sospol/ soccare/.

Velkommen til Island - oplysninger om social sikring i Island. Tryggingastofnun Ríkisins. Oktober 2002.

Winther, Gorm (1999) "The Affinity between Ownership and Social Coordination Mechanisms in Greenland”, i Pedersen, Hanna och Birger Poppel (red.) (1999) Dependency, Autonomy, Sustainability in the Artcic. Aldershot: Ashgate Publ. Ltd, 151-169.

Winther, Gorm (2004) Productivity Studies in Greenland. Methodlogical Problems and Research Design. 
Research Report no. 1. Productivity Studies in Greenland. Paper presenterat vid Nordiska Ministerrådets Välfärdsforskningsprograms konferens i Torshavn 2-3 september 2004.

Winther, Gorm (red) (2003a) Demokrati og magt i Grønland. Aarhus: Aarhus universitetsforlag. Winther, Gorm (red) (2003a) Faglig kompetence hos arbejdsstyrken $i$ Vestnorden 2003:207. Köpenhamn: Nordiska Ministerrådet.

Women and Men in Iceland 2004.

Hagstofa Íslands. www.hagstofa.is. Aaen-Larsen, Birger (2001) Børnedødligheden i Grønland 19871999. Uppsats i Folkhälsovetenskap, MPH 2001:3. Göteborg: Nordiska: Hälsovårdshögskolan. 